UNIVERSIDADE DE SÃO PAULO

FACULDADE DE FILOSOFIA, LETRAS E CIÊNCIAS HUMANAS

DEPARTAMENTO DE LETRAS CLÁSSICAS E VERNÁCULAS

PROGRAMA DE PÓS-GRADUAÇÃO EM FILOLOGIA E LÍNGUA PORTUGUESA

\title{
EXPRESSÃO DO OBJETO INDIRETO NO \\ PORTUGUÊS BRASILEIRO: TESTEMUNHO \\ LINGUÍSTICO EM PEÇAS DE TEATRO DOS \\ SÉCULOS XIX E XX
}

(VERSÃO CORRIGIDA)

São Paulo

2013 


$$
\text { UNIVERSIDADE DE SÃO PAULO }
$$

FACULDADE DE FILOSOFIA, LETRAS E CIÊNCIAS HUMANAS

DEPARTAMENTO DE LETRAS CLÁSSICAS E VERNÁCULAS

PROGRAMA DE PÓS-GRADUAÇÃO EM FILOLOGIA E LÍNGUA PORTUGUESA

\section{EXPRESSÃO DO OBJETO INDIRETO NO PORTUGUÊS BRASILEIRO: TESTEMUNHO LINGUÍSTICO EM PEÇAS DE TEATRO DOS SÉCULOS XIX E XX (VERSÃO CORRIGIDA)}

De Acordo

Dissertação apresentada ao Programa de Pósgraduação em Filologia e Língua Portuguesa do Departamento de Letras Clássicas e Vernáculas da Faculdade de Filosofia, Letras e Ciências Humanas da Universidade de São Paulo, como requisito para a obtenção do título de Mestre.

Orientadora: $\operatorname{Prof}^{\mathrm{a}}$. Dr ${ }^{\mathrm{a}}$. Maria Aparecida Correa Ribeiro Torres Morais. 


\section{EXPRESSÃO DO OBJETO INDIRETO NO PORTUGUÊS BRASILEIRO: TESTEMUNHO LINGUÍSTICO EM PEÇAS DE TEATRO DOS SÉCULOS XIX E XX}

Banca examinadora

Prof $^{\mathrm{a}}$. Dr ${ }^{\mathrm{a}}$. Maria Aparecida Correa Ribeiro Torres Morais

Instituição: USP - Presidente

Prof $^{\mathrm{a}}$. Dr ${ }^{\mathrm{a}}$. Rosane de Andrade Berlinck

Instituição: UNESP - Araraquara - Titular

Prof $^{\mathrm{a}}$. Dr ${ }^{\mathrm{a}}$. Márcia Santos Duarte de Oliveira

Instituição: USP - Titular

Prof. Dr. Emílio Gozze Pagotto

Instituição: UNICAMP - Suplente

Prof $^{\mathrm{a}}$. Dr ${ }^{\mathrm{a}}$. Maria Clara Paixão de Sousa

Instituição: USP - Suplente

Prof $^{\mathrm{a}}$. Dr ${ }^{\mathrm{a}}$. Marilza de Oliveira

Instituição: USP - Suplente 
Dedico esta dissertação de mestrado à minha mãe Luzia Yaeko Yamauchi, ao meu pai Hideo Yamauchi, à minha irmã Elaine, à minha irmã Veridiana, ao meu amor Jonatan, ao meu sobrinho Pedro, à minha afilhada Camila, aos meus queridos amigos e a todos que torceram e colaboraram para a concretização desse trabalho. 


\section{AGRADECIMENTOS}

Em primeiro lugar, agradeço a Deus por tudo e, principalmente, por ter colocado em minha vida pessoas que me ajudaram e me apoiaram, possibilitando a concretização desse sonho tão esperado: cursar o mestrado.

Agradeço à Prof ${ }^{\mathrm{a}}$. Dr ${ }^{\mathrm{a}}$. Maria Aparecida Correa Ribeiro Torres Morais pela orientação, pela confiança e por toda a compreensão. A realização deste trabalho somente foi possível graças à sua orientação.

À Prof ${ }^{a}$. Dr ${ }^{\mathrm{a}}$. Deize Crespim Pereira pela co-orientação, pelas considerações na banca de qualificação e pela enorme contribuição na pesquisa quantitativa. Agradeço também pelo curso de Goldvarb, que foi fundamental para os resultados deste trabalho.

À Prof ${ }^{a}$. Dr ${ }^{a}$. Maria Clara Paixão de Sousa pelas contribuições na banca de qualificação e pelas aulas que tanto contribuíram para a composição desta dissertação.

Ao Prof. Dr. Emilio Gozze Pagotto pelas excelentes sugestões e pelas aulas que também foram de grande contribuição para a análise teórica e quantitativa deste trabalho.

Aos queridos amigos do mestrado que eu tive a oportunidade de conhecer, conviver e compartilhar essa fase tão importante da minha vida.

Aos meus eternos e queridos amigos de toda a vida, que sempre torceram por mim, em especial, à minha amiga e comadre Viviane Regina Dantolo Delbono pela amizade de 28 anos.

À minha afilhada e querida Camila Delbuono Araújo pelo amor e carinho sempre.

Ao meu querido sobrinho Pedro Yusuke Yamauchi Cioti de Souza pelo amor, carinho e por tornar a minha vida mais alegre.

Às minhas irmãs Elaine Yuka Yamauchi e Veridiana Mayumi Yamauchi pelo amor, apoio e paciência.

Em especial, agradeço à minha mãe, Luzia Yaeko Yamauchi, e ao meu pai, Hideo Yamauchi, pela minha existência, pelo amor, pela dedicação, incentivo, apoio e compreensão em todos os momentos.

E, finalmente, ao meu grande amor e futuro marido Jonatan Cioti de Souza pelo amor, paciência, apoio, compreensão, dedicação, companheirismo e pela família que formaremos. 


\section{RESUMO}

Estudos que tratam da sintaxe dos objetos indiretos (OI) no português brasileiro (PB), com base em dados coletados de fonte documental histórica, revelam o uso variado das preposições a e para com OIs interpretados como recipiente/meta, no contexto dos verbos de transferência e movimento, entre eles, dar, levar, e outros. Tais estudos revelam ainda a ausência da preposição $a$ com os chamados verbos de criação, entre eles, construir, desenhar, pintar, etc. nos quais OI é interpretado como beneficiário. Outro fato relacionado aos anteriores pode ser descrito da seguinte forma: no $\mathrm{PB}$, o OI não mais é expresso pelos clíticos dativos de 3 a pessoa. Tal estratégia está restrita à escrita formal. Isso sugere que sua expressão morfológica foi afetada.

Nosso principal objetivo nesta dissertação é contribuir com novas evidências dos aspectos dinâmicos que caracterizam a variação e mudança na história do $\mathrm{PB}$, com base em um corpus constituído de dados extraídos de peças teatrais dos séculos XIX e XX. Como será mostrado, nossos resultados corroboram os estudos anteriores: há uma forte queda na frequência dos clíticos dativos em seu uso de $3^{\mathrm{a}}$ pessoa. Estes deixam de ser a estratégia principal na expressão do OI pronominal.

Com base em Torres Morais \& Salles (2010) e trabalhos subsequentes, assumimos que a mudança paramétrica na gramática do PB pode ser descrita como a perda do núcleo aplicativo baixo que introduz o OI dativo em estruturas bitransitivas. A configuração em que uma preposição lexical introduz o OI como seu complemento oblíquo é a única opção encontrada no PB.

Por ser um modelo internalista, a Teoria dos Princípios e Parâmetros propõe que a mudança sintática é ativada durante o processo de aquisição da língua materna. A mudança no valor de um parâmetro é catastrófica: uma vez fixado na fase de aquisição da linguagem não poderá ser refixado (cf. Lightfoot, 1979, 1997, 1999). Este tipo de abordagem, porém, não traz respostas para as questões que se referem à dinâmica da mudança sintática.

Portanto, seguindo Roberts (2007), assumimos que é perfeitamente possível e desejável que se busque conciliar a abordagem proposta no quadro da teoria dos P\&P e a abordagem proposta na Teoria da Variação e Mudança Linguística, tal como formulada por Weinreich, Labov \& Hersog (1968) eLabov (1972, 1994).Assumimos ainda a ideia da competição de gramáticas, como proposta por Kroch (1989, 2000, 2001). 


\begin{abstract}
Studies on the syntax of indirect objects (IO) in Brazilian Portuguese (BP), with data collected from a varied source of historical documents, reveal the variable use of the prepositions $a$ and para introducing the recipient/goal argument, with predicates of transference, such as dar (to give), etc. Another relevant fact is that the preposition $a$ is lost in contexts in which the IO is interpreted as the benefactive, with verbs of creation, such as construir (to build), etc., being replaced by para. Also, a related property is that the IO is no longer expressed by the $3^{\text {rd }}$ person dative pronoun lhe, suggesting that its morphological expression is affected.

Our main goal is to contribute to this aspect of variation and change in the history of BP from the perspective of a new data extracted from $19^{\text {th }}$ and $20^{\text {th }}$ centuries plays. Our results corroborate previous studies: there is a strong decrease in the frequency of $3^{\mathrm{a}}$ person dative clitics as a main strategy on the expression of the pronominal IO.

Based on Torres Morais \& Salles (2010) and subsequent studies we assume a parametric change in the BP grammar, described as the loss of the low applicative head that introduces the dative IO in ditransitive contexts. Thus configuration with the lexical/true preposition is the only option found in (Standard) BP.

As an internalist model, the Principles and Parameters Theory assumes that syntactic change is driven by the first-language acquisition process. Consequently the parametric change is catastrophic in each individual in process of learning the mother tongue (cf. Lightfoot, 1979, 1997, 1999). This kind of approach is not insightful for a number of questions concerning the dynamics of syntactic change.

Then, following Roberts (2007) we assume that it is perfectly possible and desirable to reconcile the P\&P approach with the Theory of Variation and Change, as proposed by Weinreich, Labov \&Hersog (1968) e Labov $(1972,1994)$.

We assume also the ideia of competing grammar as proposed by Kroch (1989, 2000, 2001).
\end{abstract}




\section{SUMÁRIO}

Introdução.

1. O que é o objeto indireto? Em busca de uma definição com base na história do português brasileiro.

1.1 O objeto indireto no português europeu...................................................... 16

1.2 O objeto indireto na gramática tradicional................................................. 19

1.3 A nova gramática de Castilho................................................................ 23

1.4 Um olhar histórico para o OI no PB......................................................... 26

1.4.1 Análises do português brasileiro e do português europeu...................... 26

1.4.1.1 A expressão do OI na língua falada............................................. 28

1.4.1.2 O OI no PB do século XIX: comparação com o PB moderno........ 32

1.4.1.3 Os estudos do Torres Morais \& Berlinck (2006, 2007): ampliando a base empírica e a abordagem teórica da mudança.............. 39

1.4.1.4 Uma proposta teórica para o OI no PE e PB................................. 43

1.5 Outros estudos comparativos do PE e PB.................................................. 48

1.6 Proposta de análise ...................................................................................... 52

2. Fundamentos teóricos e metodológicos.............................................................. 56

2.1 Abordagem paramétrica e mudança sintática................................................ 57

2.2 A aquisição da linguagem e a variação sintática........................................... 60

2.3 Fatores externos da mudança sintática: a Teoria da Variação e Mudança

Linguísticas......................................................................................... 63

2.4 Um olhar mais atento para a dinâmica da mudança..................................... 65

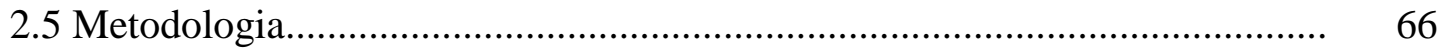

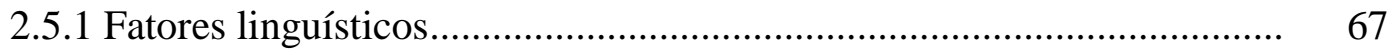

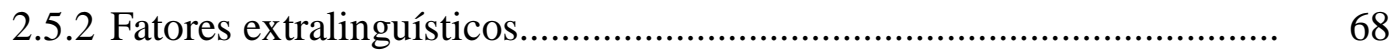

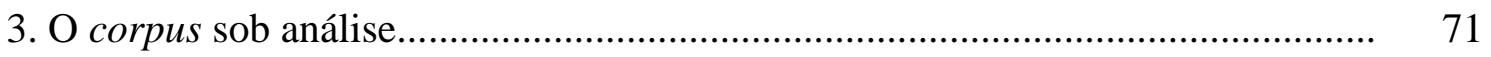

3.1 Peças de teatro do século XIX .................................................................. 72

3.1.1 Martins Pena................................................................................... 73

3.1.2 José de Alencar........................................................................... 75

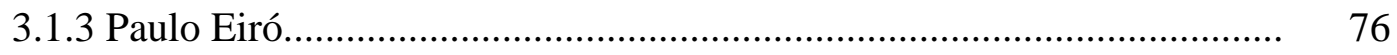

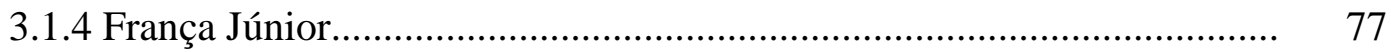

3.1.5 Artur Azevedo................................................................................... $\quad 78$ 
3.2 Peças de teatro do século XX.................................................................... 79

3.2.1 Machado de Assis............................................................................... $\quad 79$

3.2.2 Claudio de Souza............................................................................... 80

3.2.3 Gastão Tojeiro............................................................................ 80

3.2.4 Oswald de Andrade...................................................................... 81

3.2.5 Nelson Rodrugues..................................................................... 82

3.2.6 Jorge Andrade................................................................................ 82

3.2.7 Os autores contemporâneos.................................................................. 83

4. Análise dos dados............................................................................................ 85

4.1 Resultados da análise quantitativa.......................................................... 87

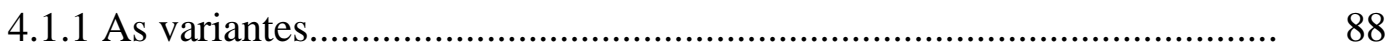

4.1.2 Fatores linguísticos........................................................................ 89

4.1.2.1 Contextos verbais...................................................................... 89

4.1.2.2 Papel temático............................................................................. 97

4.1.2.3 Natureza semântica do OI............................................................ 99

4.1.2.4 Pessoa gramatical........................................................................... 101

4.1.2.5 Fator clítico...................................................................... 103

4.1.2.6 Preposição............................................................................. 104

4.1.3 Fatores extralinguísticos............................................................... 106

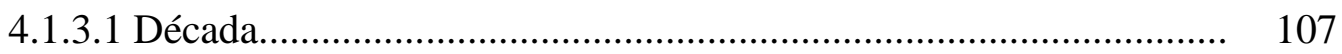

4.1.3.2 Gênero das peças..................................................................... 110

4.1.3.3 Classe social....................................................................... 112

4.1.3.4 Gênero das personagens......................................................... 113

4.2 Resultados dos cruzamentos.................................................................. 115

4.2.1 $\mathrm{O}$ fator década............................................................................. 115

4.2.1.1 O fator década e o contexto verbal............................................... 115

4.2.1.2 O fator década e a pessoa gramatical.......................................... 119

4.2.1.3 O fator década e o clítico............................................................. 120

4.2.1.4 O fator clítico e a preposição.......................................................... 121

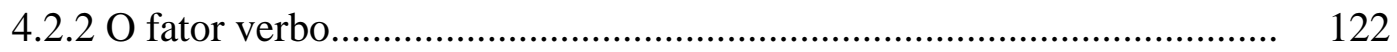

4.2.2.1 O fator verbo e o papel temático.................................................. 122

4.2.2.2 O fator verbo e o clítico............................................................. 123

4.2.2.3 O fator verbo e a preposição..................................................... 123 
4.2.3 O fator clítico.

Considerações finais...................................................................................... 126

Referências bibliográficas...................................................................................... 128 


\section{ÍNDICE DE TABELAS}

Tabela 1. Forma do objeto indireto segundo a pessoa gramatical........................... 28

Tabela 2. Forma do objeto indireto segundo a animacidade do referente................. 29

Tabela 3. Forma do OI anafórico segundo a pessoa gramatical do complemento.... 32

Tabela 4. Distribuição das ocorrências de OI anafórico segundo a forma do complemento, no PBM.

Tabela 5. Distribuição dos dados computados segundo a variante usada................. $\quad 48$

Tabela 6. Distribuição do clítico lhe segundo a pessoa gramatical.......................... 49

Tabela 7. Distribuição das variantes tônicas segundo a preposição regente............. 50

Tabela 8. Distribuição dos dados segundo as variantes do OI................................. 88

Tabela 9. Distribuição dos dados segundo as variantes do OI de $3^{\text {a }}$ pessoa............ $\quad 88$

Tabela 10. Distribuição dos dados segundo as variantes do OI de $2^{\mathrm{a}}$ pessoa............ 89

Tabela 11. Distribuição das variantes segundo os tipos de verbos............................ 91

Tabela 12. Distribuição das variantes de $3^{\text {a }}$ pessoa segundo os tipos de verbos...... $\quad 92$

Tabela 13. Distribuição das variantes segundo o papel temático............................. 98

Tabela 14. Distribuição das variantes de $3^{\text {a }}$ pessoa segundo o papel temático.......... 98

Tabela 15. Distribuição das variantes segundo a animacidade................................ 100

Tabela 16. Distribuição das variantes de $3^{\mathrm{a}}$ pessoa segundo a animacidade............. 100

Tabela 17. Distribuição das variantes segundo a pessoa gramatical........................ 102

Tabela 18. Distribuição das ocorrências dos clíticos................................................ 103

Tabela 19. Distribuiçãa das ocorrências das preposições........................................ 105

Tabela 20. Distribuição das ocorrências de $3^{\mathrm{a}}$ pessoa com as preposições............... 105

Tabela 21. Distribuição das variantes de $2^{\mathrm{a}}$ e $3^{\mathrm{a}}$ pessoasao longo dos séculos......... 107

Tabela 22. Distribuição das variantes de $3^{\mathrm{a}}$ pessoa ao longo dos séculos................. 108

Tabela 23. Distribuição das variantes segundo o gênero das peças de teatro............ 111

Tabela 24. Distribuição das variantes segundo a classe social das personagens....... 112

Tabela 25. Distribuição das variantes segundo o gênero das personagens................ 113

Tabela 26. Distribuição das variantes de $3^{\text {a }}$ pessoa segundo o gênero das

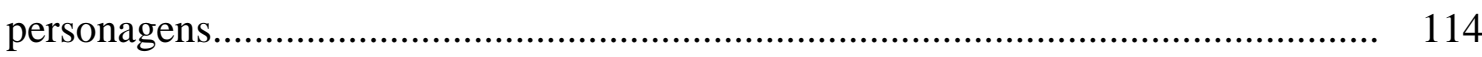

Tabela 27. Frequência das variantes segundo as décadas e os tipos de verbos......... 116

Tabela 28. Frequência das variantes de $3^{\text {a }}$ pessoa segundo as décadas e os tipos de verbos. 
Tabela 29. Distribuição das variantes de $3^{\mathrm{a}}$ pessoa segundo as décadas

Tabela 30. Distribuição das variantes de $2^{\text {a }}$ pessoa segundo as décadas......

Tabela 31. Distribuição das ocorrências segundo as décadas e o fator clítico

Tabela 32. Distribuição das ocorrências segundo as décadas e as preposições

Tabela 33. Distribuição das ocorrências de $3^{\text {a }}$ pessoa segundo as décadas e as preposições.

Tabela 34. Distribuição das ocorrências de $3^{\text {a }}$ pessoa segundo o tipo de verbo e o papel temático.

Tabela 35. Distribuição das ocorrências segundo o tipo de verbo e o fator clítico... 123

Tabela 36. Distribuição das ocorrências segundo o tipo de verbo e a preposição.....

Tabela 37. Distribuição das ocorrências segundo o fator clítico e a pessoa 


\section{ÍNDICE DE GRÁFICOS}

Gráfico 1. Emprego das preposições a / para na expressão do dativo, em corpora de anúncios e cartas de leitores / redatores............................................................... 43

Gráfico 2. As variantes e os tipos de verbos...................................................... 92

Gráfico 3. As variantes de $3^{\text {a }}$ pessoa e os tipos de verbos...................................... 94

Gráfico 4. As variantes de $2^{\mathrm{a}}$ e $3^{\mathrm{a}}$ pessoas e os séculos......................................... 108

Gráfico 5. As variantes de $3^{\mathrm{a}}$ pessoa e os séculos................................................. 109

Gráfico 6. O clítico the de $3^{\mathrm{a}}$ pessoa segundo os verbos e os séculos...................... 118

Gráfico 7. O fator clítico e a pessoa gramatical.................................................... 125

\section{ÍNDICE DE FIGURAS}

Figura 1. Frequência de OI segundo a forma do complemento em M. Pena,

S. Lopes e no PBM

Figura 2. Forma do OI anafórico segundo a pessoa gramatical do complemento nos dados do PBM.

Figura 3. Forma do OI anafórico de $1^{\text {a }}$ pessoa nas comédias de M. Pena, de

S. Lopes e no PBM.

Figura 4. Forma do OI anafórico de $2^{\mathrm{a}}$ pessoa nas comédias de M. Pena, de

S. Lopes e no PBM

Figura 5. Forma do OI anafórico de $3^{\text {a }}$ pessoa nas comédias de M. Pena, de

S. Lopes e no PBM

Figura 6. Preposição do OI oblíquo nas comédias de M. Pena, de S. Lopes

e nos dados do PBM (PEUL e JUC)

Figura 7. Estrutura aplicativa

Figura 8. Estrutura preposicionada. 46

Figura 9. Estrutura preposicionada 


\section{INTRODUÇÃO}

O presente trabalho foi estruturado de forma a abordar as realizações pronominais do objeto indireto de $3^{\mathrm{a}}$ pessoa, na história recente do português brasileiro, num conjunto de peças teatrais dos séculos XIX e XX.

Consideraremos três possibilidades de realização do objeto indireto anafórico: clítico dativo lhe, preposição + pronome forte (a/para ele(s)/ela(s)) e forma nula fonologicamente. Como suporte para as nossas reflexões, buscamos ainda os fatos

relacionados à $2^{\mathrm{a}}$ pessoa pronominal, a saber: clítico te, preposição + pronome forte (a/para você(s)) e forma nula.

Os contextos gramaticais escolhidos são os verbos bitransitivos/ditransitivos, semanticamente interpretados como verbos de movimento/transferência e os verbos de criação.

Nos últimos anos, resultados de pesquisas linguísticas vêm demonstrando processos de variação e mudança no português brasileiro, no que diz respeito ao objeto indireto. Dentre eles, destacam-se a queda dos clíticos e a substituição da preposição $a$ pela preposição para como introdutora de objetos indiretos pronominais e lexicais. Observou-se ainda o aumento do objeto indireto nulo.

No entanto, ao contrário do que ocorreu com os clíticos acusativos $o, a, o s, a s$, que se restringiram aos usos cultos de $3^{\mathrm{a}}$ pessoa, com os clíticos lhe/lhes houve um aumento de sua produção, para se referir à $2^{\mathrm{a}}$ pessoa.

Todos estes movimentos, portanto, vão delineando o perfil gramatical do português brasileiro que o separa do português europeu.

Este estudo toma como base analítica os pressupostos teóricos e metodológicos da Teoria dos Princípios e Parâmetros e da Teoria da Variação e Mudança Linguísticas. As hipóteses abaixo expressam uma expectativa com relação ao percurso das três variantes de nossa variável dependente, ao longo dos períodos estudados:

(a) os clíticos se tornam a variante menos produtiva;

(b) as formas pronominais nulas e o pronome tônico passam a ser as formas mais frequentes; 
(c) ocorre a substituição da preposição $a$ pela preposição para, introdutoras do objeto indireto anafórico;

(d) ocorre a migração do pronome lhe ( $3^{\mathrm{a}}$ pessoa) para a $2^{\mathrm{a}}$ pessoa, causando a competição entre o clítico lhe e o clítico te.

Esta dissertação está estruturada em quatro capítulos.

O capítulo 1 apresenta uma reflexão a respeito da função objeto indireto e das diferentes terminologias que têm sido usadas para defini-la. Destacaremos que a variação terminológica está condicionada aos diferentes tipos de abordagens que decorrem ora de uma visão normativa, ora de uma visão descritiva, ora de uma perspectiva mais teórica.

Em particular destacamos o fato de que, para obter uma definição mais precisa do objeto indireto no português brasileiro, é fundamental se apoiar em uma perspectiva comparativa que levem em conta os fatos de variação e mudança que hoje diferenciam o português brasileiro do português europeu.

No $2^{\circ}$ capítulo, descrevemos os pressupostos teóricos da Teoria dos Princípios e Parâmetros e da Teoria da Variação e Mudança Linguísticas. Enquanto a teoria paramétrica tem uma visão internalista da mudança, propondo que esta ocorre na fase da aquisição da linguagem, por fixação de parâmetros, a teoria variacionista oferece o pressuposto de que a variação que precede a mudança linguística é condicionada por fatores de natureza gramatical/estrutural e social. Oferece ainda o arcabouço metodológico necessário para se traçar no tempo real o percurso da mudança.

Apresentaremos ainda os fatores ou variáveis independentes que foram selecionadas para a análise do nosso fenômeno.

Já no $3^{\circ}$ capítulo, descreveremos o corpus sob análise constituído de peças de teatro dos séculos XIX e XX. Faremos uma breve apresentação de cada uma das peças escolhidas.

A última parte da dissertação, o capítulo 4, contém a descrição, análise e interpretação dos resultados percentuais obtidos, levando em conta os programas de cálculos do Goldvarb, sobre os fatores linguísticos e sociais que determinaram a variação e mudança observada. 
E por fim, sintetizaremos os resultados mais relevantes da pesquisa nas considerações finais.

Espera-se com este trabalho uma contribuição para a ampliação dos estudos sobre o objeto indireto no português brasileiro. 


\section{CAPÍTULO 1}

\section{O que é o objeto indireto? Em busca de uma definição com base na história do português brasileiro}

Uma das preocupações desta dissertação de mestrado, que tem como objetivo central descrever e analisar as estratégias de realização do objeto indireto (OI) em peças de teatro dos séculos XIX e XX, é a questão da definição do objeto de estudo. De fato, os diferentes gramáticos e linguistas têm revelado uma variação terminológica, e se referem ao segundo objeto dos predicados bitransitivos ora como objeto/complemento indireto, ora como objeto/complemento dativo.

Da mesma forma, não há consenso sobre a identificação dos predicados bitransitivos. Seriam bitransitivos somente os predicadores que selecionam um objeto direto e um objeto indireto como complementos? Ou seriam bitransitivos todos os predicados que selecionam dois argumentos internos, independentemente da interpretação do objeto introduzido por preposição?

Embora a segunda questão não seja um dos nossos objetos de reflexão, a que se refere ao estatuto do objeto indireto se torna crucial, uma vez que o português brasileiro (PB) se diferencia do português europeu (PE) na codificação desta função.

Neste capítulo, faremos inicialmente a revisão de algumas gramáticas tradicionais e de alguns trabalhos acadêmicos. Em seguida, com base em evidências de natureza histórica e comparativa, mostraremos que os critérios que dão conta do comportamento sintático do objeto indireto no português europeu não podem ser adotados para identificálo no português brasileiro.

\subsection{O objeto indireto no português europeu}

Mateus et al. (2003),em sua Gramática da Língua Portuguesa, distinguem os argumentos preposicionados com base em características semânticas e formais particulares. Desta forma é feita uma distinção entre objeto indireto e complemento 
oblíquo. O objeto indireto é definido como o argumento de verbos de dois ou três lugares, com o traço [+animado] e que apresenta, tipicamente, a função semântica de Alvo ( ex. 1a) ou Fonte (1b): ${ }^{1}$

(1) a. O João ofereceu um CD [ao Pedro $]_{\mathrm{OI}}$

b. O João comprou esse livro raro [a um alfarrabista do Porto $]_{\mathrm{OI}}$

Em alguns casos, porém, ocorre objeto indireto [-animado]:

a) Com certos predicadores de dois lugares:

(2) a. obedecer [ao regulamento $]_{\mathrm{OI}}$.

b. sobreviver [ao massacre $]_{\mathrm{OI}}$.

b) Com dar ou fazer, seguido de um objeto direto que designa um estado de coisas:

(3) a. dar [uma pintura $]_{\mathrm{OD}}[\text { às estantes }]_{\mathrm{OI}}$

b. fazer [uma limpeza $]_{\mathrm{OD}}[\grave{a} \text { casa }]_{\mathrm{OI}}$.

Nessas construções, o constituinte em itálico pode ser realizado como complemento oblíquo:

(4) a. dar [uma pintura $]_{\mathrm{OD}}[\text { nas estantes }]_{\mathrm{OBL}}$.

b. fazer [uma limpeza $]_{\mathrm{OD}}[\text { na casa }]_{\text {oBL. }}$

Quando o OI é um pronome pessoal, apresenta a forma dativa da flexão casual: lhe/lhes:

(5) a. O miúdo deu [o brinquedo $]_{\mathrm{OD}}$ [ao amigo $]_{\mathrm{OI}}$.

b. O miúdo deu-[lhe $]_{\mathrm{OI}}$ o brinquedo.

${ }^{1}$ Cf. pp 289-299. Exemplos adaptados e renumerados. 
Nas frases básicas, um OI final ocorre imediatamente à direita de objeto direto (5a); imediatamente à direita do verbo se o OI for um clítico (5b). A ordem pode ser invertida se o OD for um SN longo ou complexo (6a-b), ou uma frase complemento (6c):

(6) a. A Ana comprou [ao Gonçalo $]_{\mathrm{OI}}$ [o quadro do vencedor da $2^{\mathrm{a}}$. Bienal de Artes Plásticas de Cerveira] $]_{\mathrm{OD}}$.

b. A Ana contou [ao Gonçalo $]_{\mathrm{OI}}$ o filme que foi ver ontem $]_{\mathrm{OD}}$.

c. O jornalista contou $[\text { aos amigos }]_{\mathrm{or}}$ [que the tinham censurado a reportagem $]_{\mathrm{OD}}$.

Por sua vez, chama-se oblíquas (OBL) às relações gramaticais que são exercidas tanto por argumentos obrigatórios, quanto argumentos opcionais do predicador verbal (adjuntos). Os oblíquos expressam semanticamente as funções de locativo, direcional, beneficiário, tempo, causa, fim e outros. Os exemplos abaixo mostram que os oblíquos são tipicamente de natureza preposicional, adverbial ou frásica ${ }^{2}$.

(7) a. O João pôs o livro [na estante $]_{\mathrm{OBL}}$

b. O cobrador foi $[a l i]_{\mathrm{OBL}}$

c. Os pais autorizaram a Rita [a acampar] oBL

d. O Pedro viajou [do México] овL [para Lisboa $]_{\mathrm{OBL}}$

e. O João trouxe [do Senegal $]_{\text {OBL }}$ essa estatueta

f. O meu amigo pintou esse quadro [para a Maria $]_{\text {овL }}$

g. Encontramo-nos todos [logo à noite] овL

h. Há falta de leite [por causa da seca $]_{\mathrm{OBL}}$

i. Tenho de sair já [para não perder o avião $]_{\mathrm{OBL}}$

O que concluímos desta apresentação das propriedades do OI é que esta função tem um estatuto particular com relação aos complementos oblíquos. Também difere o estatuto das preposições que os introduzem. A preposição $a$ que introduz o OI é definida como uma preposição esvaziada de significação, enquanto as preposições que introduzem

\footnotetext{
${ }^{2}$ Exemplos renumerados.
} 
os complementos oblíquos são semanticamente relevantes. Entendemos que a preposição $a$ pode ser definida, nestes contextos, como um marcador de caso dativo. Podemos, portanto, isolar duas propriedades identificadoras do OI, a saber:

a) o OI lexical é introduzido por $a$, um marcador de caso dativo

b) o OI pronominal é realizado, na $3^{\mathrm{a}}$ pessoa, pelos clíticos dativos lhe/lhes

Muito importante a ser destacado é o fato de que as propriedades acima apresentadas refletem, de forma precisa, os usos do português falado e escrito em Portugal. Portanto, justifica-se que tenha sido feita uma distinção entre o OI e complementos oblíquos, os quais são introduzidos por uma ampla gama de preposições, sem a possibilidade da pronominalização pelos clíticos lhe/lhes.

Vejamos, a seguir, o que encontramos em algumas de nossas gramáticas da Língua Portuguesa a respeito da caracterização do OI.

\subsection{O objeto indireto na gramática tradicional}

Nesta seção, procuramos apresentar as definições do OI encontradas em gramáticas tradicionais, ora definidas desse modo por apresentarem cunho normativo e prescritivo, ora por levarem sempre em consideração as regras obtidas através de exemplos extraídos de textos de escritores consagrados, ora por privilegiarem a combinação e organização que tais escritores dispensam às palavras de seus textos, restringindo, dessa forma, seus exemplos à língua escrita.

Para Cunha e Cintra (2001) o OI é o complemento preposicionado de verbos intransitivos e verbos transitivos que selecionam um OD e um OI. Não há distinção entre uma preposição especializada em introduzir OI, em oposição às preposições que introduzem argumentos oblíquos. Cunha \& Cintra observam ainda que o OI pode ser representado por diferentes categorias: ${ }^{3}$

\footnotetext{
${ }^{3}$ Exemplos renumerados. Conservamos, porém, a terminologia do autor, por exemplo os termos substantivo, numeral, etc., ao invés de SN.
} 
a) substantivo:

(8) Duvidava da riqueza da terra

b) pronome (substantivo):

(9) Inserir-se em Roma é mais difícil do que incorporar-se a si o sentimento de Roma.

c) numeral:

(10) Os domingos, porém, pertenciam aos dois.

d) palavra ou expressão substantivada:

(11) Mas - quem daria dinheiro aos pobres?

e) oração substantiva (objetiva indireta):

(12) A mãe contava e recontava as duas malas tentando convencer-se de que ambos estavam no carro.

Acrescentam, também, que os pronomes oblíquos lhe/lhes são, essencialmente, OI. Vejamos o exemplo: ${ }^{4}$

(13) As noites não the trouxeram repouso, mas deram-lhe, em contrapartida, tempo para a meditação.

Outro fato apontado é em relação ao OI pleonástico, conhecido nas teorias linguísticas correntes como redobro do clítico. O redobro se define pelo emprego de duas formas: uma forma pronominal forte, introduzida por preposição, e um pronome clítico que a redobra. Assim: Quem lhe disse a você que estavam no palheiro? Ou, Aos meus escritos, não lhes dava importância nenhuma. Os autores mostram que o redobro tem como finalidade realçar o complemento indireto.

\footnotetext{
${ }^{4}$ Exemplo renumerado.
} 
No entanto, embora não reconheçam a preposição $a$ como introdutora única do OI, os gramáticos fazem a seguinte observação: Enquanto a preposição que encabeça um adjunto adverbial possui claro valor significativo, a que introduz o objeto indireto apresenta acentuado esvaziamento de sentido (p. 145)

Por sua vez, Rocha Lima (2003) propõe o termo complemento relativo para designar o argumento do verbo encabeçado por preposição necessária que não pode ser convertido, na terceira pessoa, em clítico dativo.

Assim, segundo o autor, o termo OI fica reservado para o argumento do verbo que apresentar essa possibilidade de conversão. $\mathrm{O}$ complemento relativo corresponderia às formas tônicas ele, ela, eles, elas, precedidas de preposição: assistir a um baile - assistir a ele; anuir a uma proposta - anuir a ela; depender de despacho - depender dele; gostar de uvas - gostar delas.

De acordo com Rocha Lima (2003:249), o OI não se limita a verbos bitransitivos ou transitivos indiretos, podendo aparecer com qualquer tipo de predicado (verbal, nominal ou verbo-nominal), ocorrendo inclusive com de verbos de ligação e verbos na voz passiva. Todos os possíveis contextos estão abaixo ilustrados ${ }^{5}$ :

(14) a. Dar esmola a um mendigo (Dar-lhe esmola).

b. Mandei flores para a noiva (Mandei-lhe flores).

c. Beijar o anel ao cardeal (Beijar-lhe o anel).

d. Ter respeito aos mais velhos (Ter-lhes respeito).

e. O ancião fez saber aos herdeiros a sua última vontade (Fez-lhes saber).

f. A prova pareceu difícil aos estudantes (Pareceu-lhes difícil).

g. Obedecer aos superiores (Obedecer-lhes).

h. O documento foi entregue ao ministro por mim (Foi-lhe entregue).

Bechara (2001) tem uma descrição do OI no português que se identifica bastante com o que foi descrito para os usos lusitanos em Mateus et. al (2003). Segundo ele, o OI é o sintagma que pode ser comutável pelo pronome pessoal objetivo lhe/lhes, denotando relação a um ser animado e apresentando características formais e semânticas de

\footnotetext{
${ }^{5}$ Exemplos renumerados.
} 
"beneficiário" e "destinatário". Na definição de Bechara, o OI é introduzido apenas pela preposição $a$, raramente pela preposição para. Para nomear os complementos de verbos como assistir, gostar, etc., Bechara usa o termo complemento relativo, a mesma terminologia usada por Rocha Lima (2003).

$\mathrm{O}$ autor reconhece a necessidade de se esclarecer esse ponto:

Cabe insistir que a preposição que introduz o complemento indireto éa;muitas vezes, parece que, nesta função, se acha a preposição para, já que a e para se alternam em muitos esquemas sintáticos, mas não quando se trata do complemento indireto, o que só raramente acontece (p.422-423).

Assim, como apontado por ele, em uma sentença como Alguns alunos compraram flores para a professora, a preposição para não introduz o OI, dada a possibilidade de coocorrência com a preposição $a$, como em: Alguns alunos compraram flores ao florista para a professora.

Além disso, a pronominalização só poderia ser realizada com o termo ao florista, evidente no contraste entre a gramaticalidade da sentença Alguns alunos compraram-lhe flores para a professora e a agramaticalidade de Alguns alunos compraram-lhe ao florista. Além do mais, não seria possível introduzir com a preposição $a$ os dois sintagmas preposicionados como em Alguns alunos compraram flores à florista $\grave{a}$ professora.

Bechara faz alusão a outras características do OI, como os dativos livres, que são termos que não estão, direta ou indiretamente, ligados à esfera do predicado, representados por ${ }^{6}$ :

a) dativo de interesse:

(15) Ele ligou-me amavelmente a luz.

b) dativo ético:

(16) Não me reprovem estas ideias!

${ }^{6}$ Exemplos adaptados e renumerados. 
c) dativo de posse:

(17) O médico tomou o pulso ao doente (tomou-lhe o pulso).

d) dativo de opinião:

(18) Para ele a vida deve ser intensamente vivida.

O gramático considera que há uma construção especial com o OI, como é o caso de um pequeno número de verbos que contraria o princípio geral adotado. São exemplos desses casos: A notícia não agradou ao povo / a notícia não lhes agradou. A mesma construção ocorre com verbos como desagradar, pertencer, acontecer, interessar, aparecer, etc.

Vale lembrar que o termo OI fica reservado para o argumento preposicionado do verbo que apresentar essa possibilidade de pronominalização pelos clíticos lhe/lhes. $\mathrm{O}$ complemento relativo corresponde às formas tônicas ele, ela, eles, elas, precedidas de preposição: assistir a um baile - assistir a ele; gostar de uvas - gostar delas.

Concluímos que, nas gramáticas aqui revisadas, não há consenso na identificação do OI, quando se leva em conta a sua natureza de argumento introduzido pela preposição a. No entanto, o teste da pronominalização foi adotado por todos, como recurso fundamental para identificá-la.

Dessa forma, pode-se dizer que a possibilidade de pronominalização do OI pelos clíticos dativos lhe/lhes representa a marca morfológica essencial que o distingue de outras funções introduzidas por preposição.

$\mathrm{Na}$ seção 1.3. apresentamos a caracterização do OI no PB na gramática de Castilho (2010).

\subsection{A nova gramática de Castilho}

Castilho (2010) apresenta em sua Nova Gramática do Português Brasileiro várias inovações que a tornam única, se a comparamos com as gramáticas tradicionais. Vamos destacar apenas uma delas, que se torna crucial para esta seção que busca encontrar a 
identificação do OI. Trata-se do fato de que Castilho descreve o PB, com base na língua falada, colhida no imenso corpus coletado pelo Projeto de Estudo da Norma Urbana Linguística Culta (Projeto NURC).

Primeiramente, o autor reconhece que há uma complicação quando ingressamos no campo do objeto indireto e do oblíquo (p. 304). O problema reside no fato de ambos os complementos serem preposicionados, daí a questão de se saber se os argumentos foram selecionados pela preposição ou pelo verbo. Castilho segue a seguinte estratégia para dar conta do OI. Primeiramente, parte dos exemplos abaixo: ${ }^{7}$

(19) a. O livro pertence a mim, a ti, ao aluno.

b. O Diretor escreveu cartas aos pais.

c. Dou esta maçã ao amigo.

Com base nesses exemplos, o linguista reconhece que as expressões em itálico funcionam como OI por exibirem as seguintes propriedades ${ }^{8}$ :

a) são proporcionais aos pronomes $m e$, te, lhe:

(20) a. O livro pertence-me, -te, -lhe.

b. O Diretor escreveu-lhes cartas.

c. Dou-lhelte esta maçã.

b) São preenchidas por sintagma preposicionado nucleado por $a$ e para, preposições que foram selecionadas, respectivamente, por pertencer, escrever, dar.

c) A construção em que figuram não é conversível à voz passiva.

d) Podem coocorrer juntamente com o objeto direto, como em (19c) Nessas construções o PB é avesso à pronominalização de ambos os complementos, habitual no PE, dadas as restrições em nosso quadro de clíticos (? O Diretor escreveu-lhas).

\footnotetext{
${ }^{7}$ Exemplos renumerados.

${ }^{8}$ Exemplos renumerados.
} 
e) O papel temático é, em geral, beneficiário.

f) Sua colocação de base é após o verbo; ocorrendo objeto direto, após este.

Já os complementos oblíquos exibem algumas propriedades que são extraídas dos exemplos abaixo (p. 305) ${ }^{9}$

(21) a. João pôs o livro na estante

b. Saio de casa mal nasce o dia e volto ao recesso do lar morto de cansaço

c. Viajei de Campinas para São Paulo pela Rodovia Bandeirantes

d. Chego ao trabalho com um cansaço precoce, coisas de grande cidade

e. Fui à festa com uma amiga, e voltei com outra, não estou entendendo nada

f. Preciso de paciência, caso contrário...

g. Não gosto de assistir às novelas

Para Castilho, as expressões em itálico funcionam como complemento oblíquo por exibirem as seguintes propriedades;

a) São proporcionais a pronomes advérbios dêiticos ou a preposição + pronome, como nos exemplos a seguir: ${ }^{10}$

(22) a. Ele pôs ele lá./Ele o pôs lá.

b. Ele viajou daqui para lá.

c. Eles precisam deles.

d. Ele contactou com ele./foi com ele.

e. Ela cortou-se com ela.

f. Ele pintou-o para ela.

g. Ele almoçou lá.

h. Ele mede isso.

i. Ela durou (tudo) isso.

\footnotetext{
${ }^{9}$ Exemplos adaptados e renumerados

${ }^{10}$ Exemplos renumerados.
} 
b) Ocorrem como argumento interno único da sentença, coocorrem com o objeto direto.

c) Ocorrem mais frequentemente com verbos de movimento.

d) Exploram com frequência o papel temático locativo.

Castilho afirma que sentenças desse tipo permitem elaborar um teste de proporcionalidade, para se poder demonstrar que as expressões preposicionadas, em itálico, funcionam como argumentos do verbo, ou seja, são constituintes centrais e obrigatórios da sentença, apresentando uma forte conexidade com o verbo por serem por ele selecionados, donde sua proporcionalidade com os pronomes pessoais.

Considerando a proporcionalidade pronominal das expressões em itálico, reconhece-se o respectivo estatuto de argumentos. Aqueles proporcionais a ele nominativo são sujeitos sentenciais. Aqueles proporcionais ao clítico o, ou a ele acusativo, são objetos diretos. Aqueles proporcionais a the, um pronome dativo, são objetos indiretos. Finalmente, aqueles proporcionais à expressão preposição + pronome pessoal/advérbio dêitico/demonstrativo neutro, são complementos oblíquos.

Os testes mais elaborados permitem, pois, uma identificação clara do OI em oposição ao complemento oblíquo.

Os OIs são realizados pelos clíticos the /hes e introduzidos por sintagmas preposicionados nucleados por $a$ e para. Já os oblíquos são proporcionais à preposição + pronome (nela, com ela, a elas).

$\mathrm{Na}$ seção seguinte vamos nos deter em alguns estudos que têm tratado o OI com base em corpus do PB falado e escrito. Alguns destes estudos retomam ainda períodos históricos.

Com eles, descobre-se uma nova face do OI no PB. Novas estratégias se apresentam para a expressão tanto do OI pronominal, quanto do OI lexical. Será dada uma atenção especial às diferentes estratégias que são usadas na expressão do OI anafórico.

\subsection{Um olhar histórico para o OI no PB}

1.4.1 Análises do português brasileiro e do português europeu 
Pode-se dizer que os trabalhos de Berlinck $(1996,1996 b, 1997)$ sobre o OI no PB são pioneiros, no sentido em que, até então, ao contrário do que se observava para o objeto direto (OD), o OI estava ainda praticamente esquecido. Na nossa revisão de seus estudos, vamos notar que, basicamente, os contextos verbais considerados para a expressão dos OIs são os que a autora classificou semanticamente como verbos bitransitivos de transferência e movimento, a saber:

a) verbos de transferência material - dar, vender, entregar, comprar, roubar, etc;

b) verbos de transferência verbal/perceptual - comunicar, dizer, confiar, revelar, explicar, declarar, mostrar, etc.;

c) verbos de movimento físico - trazer, enviar, levar, mandar, etc.;

d) verbos de movimento abstrato - oferecer, conferir, destinar, etc.

Nestes contextos verbais o esquema sintático S V OD OI realiza a seguinte grade temática: um argumento agente/causador da ação expressa pelo verbo; um argumento tema e um argumento alvo/meta e fonte/origem, que marcam o ponto final ou o ponto de partida da ação expressa pelo verbo.

Com base neste esquema, Berlinck (2005) oferece uma base empírica considerável que leva à seguinte generalização: no $\mathrm{PB}$, o OI apresenta três possibilidades de realização: sintagma preposicionado (23a) - (23b), pronome clítico dativo (23c) e categoria vazia (23d):

(23) a.João deu o livro \{para/a\} Pedro.

b. João deu o livro $\{$ para $/ a\}$ ele.

c. João deu-lhe o livro.

d. João deu o livro [cv].

Tal constatação é bastante significativa, uma vez que, pelo que colhemos nas descrições sobre o OI, apresentadas nas seções anteriores, o PB apresenta estratégias inovadoras, tanto na expressão do OI lexical, quanto na expressão do OI anafórico. No que se segue fazemos uma apresentação sucinta de seus resultados, embora suficiente para ilustrar o percurso das mudanças que se verificam no PB em oposição ao PE. 
Berlinck, em seus trabalhos, apoia-se na metodologia quantitativa da Sociolinguística Variacionista, para operar com corpus variados, o que lhe permitiu obter resultados muito interessantes, com base no levantamento dos fatores condicionadores da variação e mudança, na diacronia do OI no PB.

Dada a tendência à perda dos pronomes clíticos, deve-se supor que as alternativas não se distribuem equitativamente. A caracterização desta distribuição também pode se apoiar na metodologia quantitativa.

\subsubsection{A expressão do OI na língua falada}

Berlinck (1996b) analisou 826 dados, coletados a partir de entrevistas com jovens universitários de Curitiba (JUC). Com relação ao complemento anafórico, a autora verificou se fatores de natureza morfológica, sintática ou semântica afetariam a escolha entre pronome clítico e preposição + pronome tônico.

Os resultados gerais que ela obtém revelam a preferência pelo clítico - 58\% das ocorrências (131 casos em 226). No entanto, se a pessoa gramatical é considerada, temos resultados interessantes, em que se apresenta a assimetria entre a $1^{\mathrm{a}}$ e $2^{\mathrm{a}}$ pessoas de um lado, e a $3^{\text {a }}$ pessoa de outra. Vejamos a tabela abaixo, extraída de Berlinck ( 1996b) ${ }^{11}$ :

\begin{tabular}{|c|c|c|}
\hline $\begin{array}{c}\text { forma do } \\
\text { complemento }\end{array}$ & pronome clítico & prep. + pron. tônico \\
\hline pessoa gramatical & & \\
\hline primeira pessoa & $83 \%(90 / 108)$ & $17 \%(18 / 108)$ \\
\hline segunda pessoa & $78 \%(40 / 51)$ & $22 \%(11 / 51)$ \\
\hline terceira pessoa & $3 \%(1 / 67)$ & $97 \%(66 / 67)$ \\
\hline total & $58 \%(131 / 226)$ & $42 \%(95 / 226)$ \\
\hline
\end{tabular}

Tabela 1. Forma do objeto indireto segundo a pessoa gramatical.

\footnotetext{
${ }^{11}$ Tabela renumerada.
} 
Berlinck (1996b) afirma que Se há uma tendência ao desaparecimento do clítico dativo, esse processo parece afetar essencialmente a referência de $3^{a}$ pessoa. A perda do clítico dativo de $3^{a}$ pessoa espelha o que já se comprovou para a expressão do objeto direto com referência de $3^{a}$ pessoa (p. 2).

A distinção de pessoas também é também confirmada quando se leva em conta o traço semântico [+animado], associado à função de objeto indireto. Verifica-se uma associação preferencial entre, por um lado, traço [+animado] e pronomes clíticos e, por outro lado, traço [- animado] e SP (cf. Tabela 2). ${ }^{12}$

\begin{tabular}{|c|c|c|}
\hline $\begin{array}{c}\text { forma do } \\
\text { complemento }\end{array}$ & pronome clítico & $\begin{array}{c}\text { prep. }+ \text { pron. } \\
\text { tônico }\end{array}$ \\
\hline animacidade & & \\
\hline$[+$ animado $]$ & $61 \%(131 / 215)$ & $39 \%(84 / 215)$ \\
\hline$[-$ animado $]$ & $0 \%(0 / 11)$ & $100 \%(11 / 11)$ \\
\hline total & $58 \%(131 / 226)$ & $42 \%(95 / 226)$ \\
\hline
\end{tabular}

Tabela 2. Forma do objeto indireto segundo a animacidade do referente.

Esses resultados confirmam o traço [ + animado] como o mais característico do OI, mas, por outro lado, mostram que esse complemento também pode abrigar entidades de tipo [- animado]. No entanto, como a autora observa, o fato de todos os casos de OI [animado] se realizarem como um SP, só pode ser interpretado se considerarmos os fatores animacidade e pessoa gramatical, uma vez que a distinção [ \pm animado] é pertinente apenas para a $3^{\text {a }}$ pessoa; as pessoas do discurso são sempre [+ animado]. Assim se compreende por que os casos de OI [- animado] aparecem todos como SPs. Ou seja, todos são de $3^{\text {a }}$ pessoa. As frases em (24) ilustram esses casos: ${ }^{13}$

\footnotetext{
12 Tabela renumerada.

${ }^{13}$ Exemplos renumerados.
} 
(24) a. Daí falei que não tava muito... não tava muito interessada pela distância e tal. E que eu ia fazer Mestrado e que se eu passasse no Mestrado eu ia dar prioridade pra ele.

b. O cérebro funciona com dois computadores. Você começa a forçar um, ele não se lembra. (...) Você tem que fazer ele (forçar) uma coisa completamente diferente. Que o da frente manda a pergunta pro detrás.

As distinções de pessoa também afetam o papel temático do OI. O papel temático meta é o mais frequente no corpus. Berlinck (1996b) alcança um resultado geral em que parece haver quase um empate entre pronomes clíticos e SPs: $52 \%$ e $48 \%$, respectivamente. No entanto, quando olha as pessoas gramaticais separadamente, os SPs são mais produtivos na $3^{\mathrm{a}}$ pessoa.

Quanto ao emprego das preposições $a$ /para na introdução do OI lexical, a autora nota que a preposição para é predominante: de 202 casos, 90\% (182 ocorrências) são de [para $+\mathrm{SN}$ ]. As ocorrências da preposição $a-15$ casos - correspondem a apenas $7 \%$ do total. As preposições de e em ficam com os 3\% restantes ( 2 e 3 casos, respectivamente).

Uma observação interessante que colhemos de seu estudo é a de que, enquanto para ocorre com complementos de qualquer pessoa gramatical, a preposição $a$ só aparece no corpus com complementos de $3^{\mathrm{a}}$ pessoa, como ilustram as frases em $(25 \mathrm{a})-(25 \mathrm{~b})^{14}$ :

(25) a. E ele diz que às vezes eles têm que dar auxi/assistência ao cliente, né?

b. Daí inclusive eu disse/ inclusive propus a ela: ficaria até mais interessante que além de fazer a pesquisa, vocês brincassem.

Segundo Berlinck, a manutenção de $[\mathrm{a}+\mathrm{SN}]$ poderia ser entendida como uma alternativa mais formal para a $3^{\mathrm{a}}$ pessoa, por oposição a [para $\left.+\mathrm{SN}\right]$. Além disso, a ocorrência de clítico de $3^{\mathrm{a}}$ pessoa $($ lhe $(s))$, é muito baixa. Dessa forma, o sintagma introduzido por $a$ estaria preenchendo seu papel. Inversamente, a utilização do sintagma preposicionado com valor anafórico é a alternativa preferida com os OIs de $3^{\mathrm{a}}$ pessoa, não sendo muito frequente com a $1^{\mathrm{a}}$ e a $2^{\mathrm{a}}$ pessoas.

\footnotetext{
${ }^{14}$ Exemplos renumerados.
} 
No caso das demais pessoas, os clíticos são ainda bastante produtivos. Assim, nesse contexto, temos uma oposição clítico / para + SN.

Que estratégia estaria substituindo os clíticos na expressão do OI de $3^{\text {a }}$ pessoa? Se levarmos em consideração os resultados obtidos por Berlinck, na amostra acima comentada, concluiremos que os clíticos de $3^{\text {a }}$ pessoa estão sendo substituídos pelas formas pronominais introduzidas por preposição.

No entanto, Berlinck (1997) retoma essa mesma amostra e revela que a forma preferida para a expressão do OI anafórico é, de fato, uma categoria vazia.

Vale ressaltar que a autora menciona duas possibilidades de interpretação do complemento nulo: ou ele se encontra numa relação de correferência com um elemento já mencionado anteriormente (valor anafórico), ou ele não se refere a uma entidade única e específica, permitindo uma interpretação arbitrária de seu referente. Sua análise contemplou as duas possibilidades de realização, exemplificadas, respectivamente em (26a) - (26b).

(26) a. O Luís faz um ano que liga pra mim e eu não ligo pra ele. E eu preciso ligar $[c v]$, mas é que eu sou tão relapsa.

b. Você escutou rock'n roll do Jerry Adriani? Não é comercial. Você escutou do Jerry Adriani só o que é comercial. Eles só mostravam o que vendia [cv].

Das três possibilidades de realização do OI com interpretação anafórica, a categoria vazia é aquela que predomina no conjunto de dados analisados, representando mais da metade das ocorrências: 57\% (275 casos em 484). O pronome clítico é a segunda forma mais frequente $(26 \%$ - 126/484), restando ao sintagma preposicionado com pronome tônico a última posição em termos de uso (17\% - 83/484).

Novamente, esses resultados gerais são relativizados, quando se leva em conta a pessoa gramatical que expressa. De fato, na Tabela 3 abaixo, vemos que a categoria vazia constitui a forma predominante apenas para a $1^{\mathrm{a}}$ e a $3^{\mathrm{a}}$ pessoas. Quando a referência do complemento é de $2^{\mathrm{a}}$ pessoa, a maioria dos dados foi expressa por meio de um pronome clítico. 


\begin{tabular}{|l|l|l|l|}
\hline tipo de complemento & pronome clítico & pronome tônico & categoria vazia \\
\hline pessoa gramatical & & & \\
\hline 1a. pessoa & $38 \%(88 / 229)$ & $8 \%(17 / 229)$ & $54 \%(124 / 229)$ \\
\hline 2a. pessoa & $61 \%(37 / 61)$ & $18 \%(11 / 61)$ & $21 \%(13 / 61)$ \\
\hline 3a. pessoa & $0.5 \%(1 / 194)$ & $28.5 \%(55 / 194)$ & $71 \%(138 / 194)$ \\
\hline total & $26 \%(126 / 484)$ & $17 \%(83 / 484)$ & $57 \%(275 / 484)$ \\
\hline
\end{tabular}

Tabela 3. Forma do OI anafórico segundo a pessoa gramatical do complemento

Repensando os resultados da Tabela 3 em função do percentual dos papéis temáticos, a autora mostra ainda que os OIs com valor beneficiário e experienciador têm uma referência de $1^{\mathrm{a}}$ ou de $2^{\mathrm{a}}$ pessoa. Já os casos de meta devem se distribuir entre a $1^{\mathrm{a}}$ e a $3^{\mathrm{a}}$ pessoas.

Como Berlinck conclui, a motivação para uma tal distribuição resta a determinar. Seria possível sugerir, porém, que o processo de mudança do OI atinge especialmente os casos em que o complemento tem um papel temático meta e uma referência de $3^{\mathrm{a}}$ pessoa.

\subsubsection{2. $\quad$ O OI no PB do século XIX: comparação com o PB moderno}

Num estudo mais atual, Berlinck (1999) busca determinar como se deu a mudança na expressão do OI no PB. Para tanto apoiou-se em dois corpora. O primeiro é composto de entrevistas do JUC (Jovens universitários de Curitiba), acima comentado, e do PEUL (Programa de Estudos sobre o Uso da Língua), amalgamados no que ela chamou de PBM (Português Brasileiro Moderno). O segundo, de natureza histórica, é constituído de peças de teatro de Martins Pena (1845) e Simões Lopes Neto (1896),

A análise realizada pela autora revelou a diminuição no uso do pronome clítico dativo, a qual se insere num quadro mais amplo de mudanças no sistema pronominal do $\mathrm{PB}$, que o distanciam tanto de estágios anteriores da língua, como da variedade europeia 
atual. Vejamos a Tabela $4^{15}$, amalgamando os resultados obtidos com o PBM, para facilitar o confronto com os resultados obtidos para o século XIX. A tabela apresenta as três possibilidades de realização do OI no PBM: como sintagma preposicionado (prep.+ pronome tônico), como pronome clítico dativo, ou como uma categoria vazia.

\begin{tabular}{|l|l|}
\hline forma do complemento & frequência \\
\hline clítico dativo & $24 \%$ \\
\hline prep. + pron. tônico & $21 \%$ \\
\hline nulo anafórico & $55 \%$ \\
\hline
\end{tabular}

Tabela 4. Distribuição das ocorrências de OI anafórico segundo a forma do complemento, no PBM

A Figura 1, abaixo ${ }^{16}$, apresenta a distribuição geral desses dados segundo a forma do complemento, comparando os resultados do século XIX com os resultados do PBM.

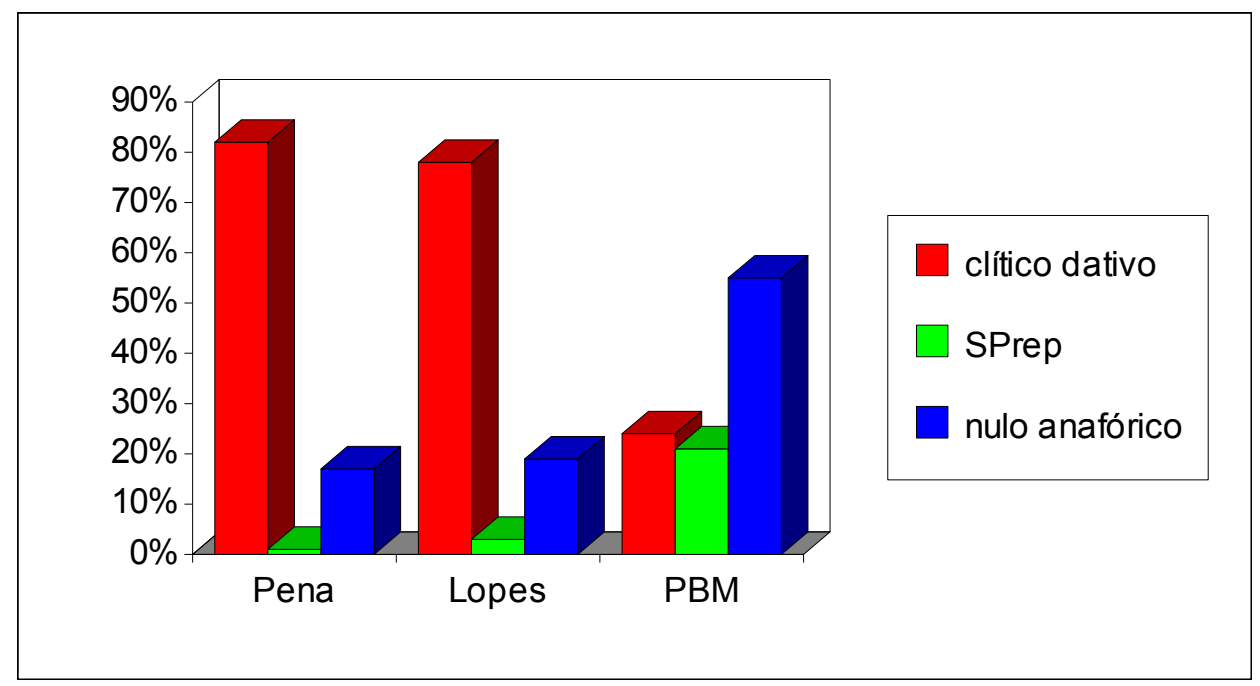

Figura 1. Frequência de OI segundo a forma do complemento em M. Pena, S. Lopes e no PBM

\footnotetext{
${ }^{15}$ Tabela renumerada.

${ }^{16}$ Figura renumerada.
} 
Observa-se que há uma diferença marcante entre os resultados da $1^{\text {a }}$ metade do século XIX e os resultados da segunda metade. No entanto, mesmo os resultados do final do século XIX diferem dos que foram obtidos com o século XX. Neste, o nulo anafórico suplanta as demais estratégias. No século XIX, a preferência está com os clíticos dativos. Note-se que o OI oblíquo ainda tem uma produtividade incipiente nos dois períodos do século XIX.

O quadro corrobora o que Berlinck tinha comprovado em seus estudos anteriores: a diminuição acentuada do uso do clítico dativo correspondeu a um aumento substancial da ocorrência do nulo anafórico e também do OI oblíquo.

A autora se volta, mais uma vez, para um refinamento dos resultados gerais, com base na pessoa gramatical do complemento. A Figura $2^{17}$ mostra-nos como a forma do OI varia em função dessas distinções no PBM.

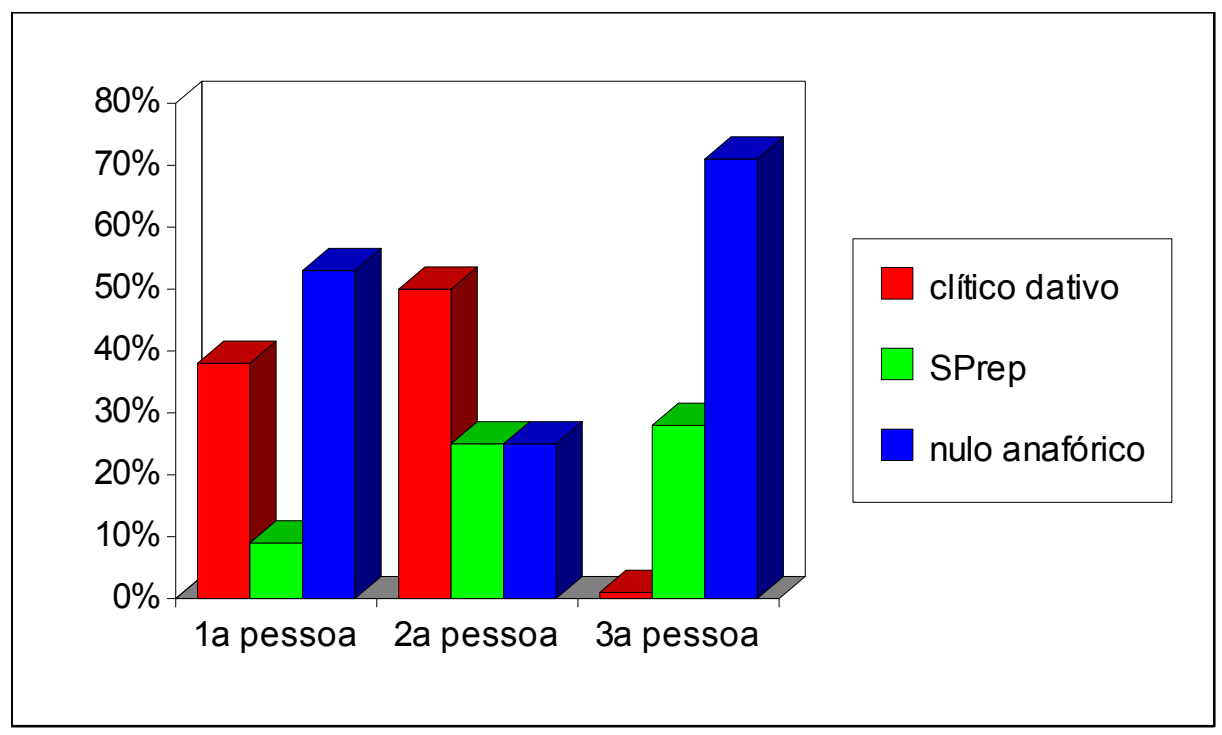

Figura 2. Forma do OI anafórico segundo a pessoa gramatical do complemento nos dados do PBM

Fica clara a predominância do nulo anafórico para a $1^{\mathrm{a}}$ e a $3^{\mathrm{a}}$ pessoas $(27 \mathrm{a}-\mathrm{b})$, com maior produtividade na $3^{\mathrm{a}}$ pessoa. Quanto ao clítico dativo, este praticamente inexiste na $3^{\mathrm{a}}$ pessoa, constituindo a segunda opção mais frequente do OI de $1^{\mathrm{a}}$ pessoa $(27 \mathrm{c})$. Por

\footnotetext{
${ }^{17}$ Figura renumerada.
} 
fim, vê-se que, no caso dos OIs de $3^{\mathrm{a}}$ pessoa, a segunda opção fica com a forma oblíqua (27d). A maior produtividade de clíticos dativos fica com a $2^{\mathrm{a}}$ pessoa. (27e).

(27) a. Que o dia que eu fui reclamar na prefeitura, a prefeitura disse $[\varnothing]$ que isso aqui era um beco-sem saída.

b. se ela tivesse dúvida de alguma coisa, chega perto de mim, sabe? se eu souber, eu explico $[\varnothing]$, eu falo $[\varnothing]$, sabe?

c. Ele me deu três mil cruzado.

d. Eu digo pra ela que eu acho que eles são alienados.

e. Tô te dizendo. Apartamento em Caiobá por menos de uma milha você não pega. Por dia.

Levando em conta a distinção de pessoas, os dados do século XIX mostram que a restrição ao uso do clítico se processou de modo diferente. Nas Figuras (3-5), a seguir, são apresentados os resultados para os OIs de $1^{\mathrm{a}}, 2^{\mathrm{a}}$ e $3^{\mathrm{a}}$ pessoas separadamente, comparando os índices dos corpora do século XIX àqueles obtidos para o PBM. ${ }^{18}$

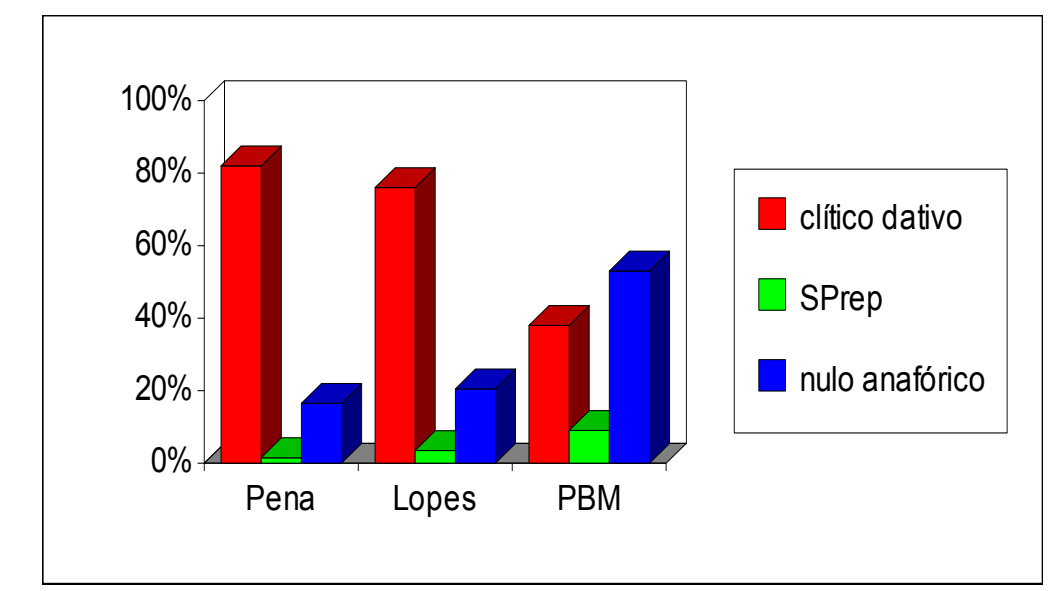

Figura 3. Forma do OI anafórico de $1^{\mathrm{a}}$ pessoa nas comédias de M. Pena, de S. Lopes e no PBM

\footnotetext{
${ }^{18}$ Figuras renumeradas.
} 


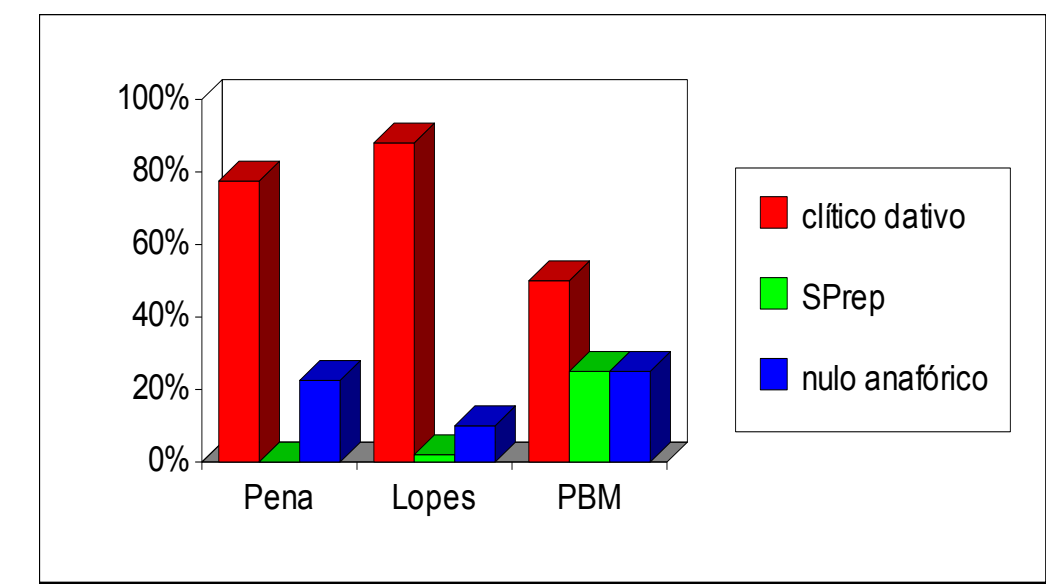

Figura 4. Forma do OI anafórico de $2^{\mathrm{a}}$ pessoa nas comédias de M. Pena, de S. Lopes e no PBM

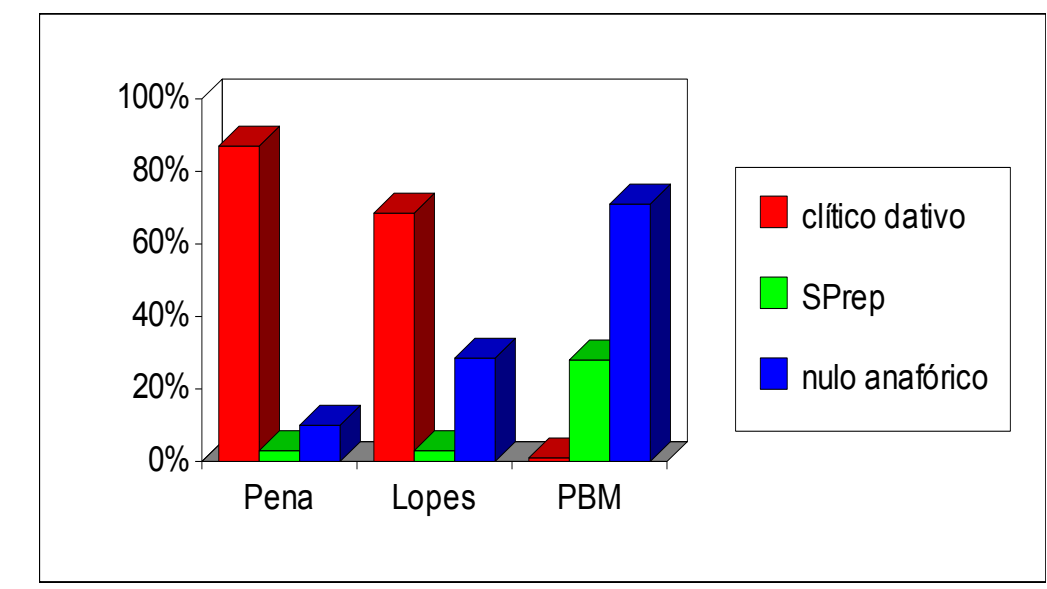

Figura 5. Forma do OI anafórico de $3^{\mathrm{a}}$ pessoa nas comédias de M. Pena, de S. Lopes e no PBM

A comparação das três figuras indica que o clítico dativo é a estratégia mais frequente no século XIX, qualquer que seja a referência de pessoa. Os dados em (28) e (29) ilustram essa tendência para Pena (1845) e Lopes (1896), respectivamente. Vejamos os exemplos selecionados por Berlinck: ${ }^{19}$

\footnotetext{
${ }^{19}$ Exemplos renumerados.
} 
(28) a. Tem gostado muito da Josefina, e pediu-ma.

b. Dous filhos te ficaram do teu primeiro matrimônio.

c. - É preciso hoje cantarmos alguma coisa, para que mostres as tuas prendas a nosso hóspede.

- Pois eu não lhe quero mostrar nada! (M. Pena).

(29) a. Você me dá bastante marmelada?

b. Nao diz nenê, eu te dou uma bengalinha...

c. Deixa estar: tua mãe chegando, vou dizer-lhe, para ela te dar umas palmadas!... (S. Lopes Neto).

Ao lado do pronome clítico, mas em menor escala, aparece o nulo anafórico, do qual os dados em (30) e (31) nos dão alguns exemplos.

(30) a. Cada um canta como sabe... O patrício pediu $[\varnothing]$ que eu cantasse, eu cantei.

b - Promete-me falar ao papá?

- Prometo $[\varnothing]$, sim.

c. Há muitas cabeças de gado, uma fazenda grande de que vai ser senhora... Podia dar $[\varnothing]$ mais, se não fosse a rebelião. Perdi muito dinheiro; não me meto noutra. (M. Pena).

(31) a. Às suas ordens, dona Eulâmpia. Se quiser ver as nouveautés de la mode, é só mandar $[\varnothing]$ um recado.

b. - Recebemos ontem umas - noveautés de la mode - artigo muito chique, $\mathrm{e}$ vim saber se desejavam alguma coisa. (...)

- A Mana depois mandará dizer $[\varnothing]$.

c. Eu vi sim! A mamãe chegando, eu vou contar $[\varnothing]$. (S. Lopes Neto).

Como Berlinck conclui, apesar do padrão geral, observam-se diferenças na passagem do momento I (Pena) para o momento II (Lopes), com a diminuição no uso do 
pronome clítico para os OIs de $1^{\mathrm{a}}$ e de $3^{\mathrm{a}}$ pessoas. O mesmo ocorre quanto ao aumento na utilização do nulo anafórico. Em ambos os casos, o processo é mais significativo com os OIs de $3^{\text {a }}$ pessoa, refletindo o movimento que vai levar ao padrão do PB moderno.

A variante oblíqua do OI anafórico, porém, é ainda pouco significativa nos dois autores do século XIX.

Segundo a autora, é interessante ressaltar que, se para o OI dativo e o OI nulo há um forte indício de mudança, para a forma oblíqua, o processo é mais demorado. $\mathrm{O}$ aumento dessa variante só se manifesta a partir do fim do século XIX, principalmente para os OIs de $3^{\text {a }}$ pessoa.

Quanto ao OI oblíquo, a análise das peças teve como objetivo avaliar a alternância das preposições $a$ e para, buscando caracterizar cada uma das diversas opções. O trecho em (32) ilustra a variação: ${ }^{20}$

(32) - Sinhozinho! Mimoso! Diga a mamãe que eu estou aqui...

- Pra mamãe eu digo; mas pra titia não digo, não! (Lopes, 1896).

A Figura $6^{21}$ apresenta a frequência de $a$ e para nos dois corpora do século XIX e, separadamente, nos dois corpora do PBM. Berlinck observa a discrepância entre os resultados do JUC e do PEUL o que impede que esses dados sejam amalgamados.

Figura 6. Preposição do OI oblíquo nas comédias de M. Pena, de S. Lopes e nos dados do PBM (PEUL e JUC)

\footnotetext{
${ }^{20}$ Exemplo renumerado.

${ }^{21}$ Figura renumerada.
}

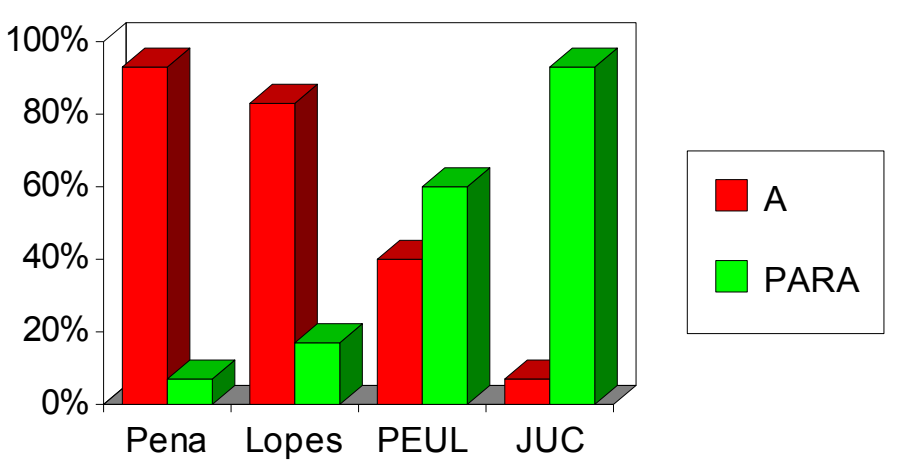


Berlinck afirma que a comparação desses resultados revela a diminuição na frequência da preposição $a$ e o aumento no uso da preposição para. Novamente, o passo mais significativo desse processo parece ter ocorrido a partir do fim do século XIX.

Assim, o PB parece ter passado, pelo menos na referência de $3^{\text {a }}$ pessoa, de um sistema misto - OI oblíquo e OI dativo - para um sistema único - apenas a possibilidade de OI oblíquo. Note-se, no entanto, que essa tipologia não está considerando a categoria vazia, que, nesse processo, tornou-se a forma preferencial de expressão do OI anafórico.

1.4.1.3. Os estudos de Torres Morais \& Berlinck (2006, 2007): ampliando a base empírica e a abordagem teórica da mudança

Em Torres Morais \& Berlinck (2006) há uma afirmação categórica: a descrição das propriedades do OI apresentada nas nossas gramáticas tradicionais contempla os usos cultos, oral e escrito, da variedade lusitana, mas não os da variedade brasileira.

Ora, como se sabe, os estudos sobre o PB moderno revelam a tendência em substituir a preposição a pela preposição para com os verbos bitransitivos de transferência ou movimento.

Além disso, há uma queda significativa no uso dos clíticos dativos de $3^{\mathrm{a}}$ pessoa.

Vamos destacar, do estudo acima mencionado, os resultados baseados em entrevistas (33a) - (33b) e anúncios (33c), coletada em revistas e jornais portugueses e brasileiros.

No caso do PE, a análise do corpus permite fazer duas afirmações: (i) o OI no contexto de verbos de transferência e movimento é introduzido categoricamente pela preposição a (33a) - (33b) - (33c); (ii) a expressão anafórica do OI se realiza exclusivamente com os clíticos dativos (33d): ${ }^{22}$

(33) a. Pediram-me, inúmeras vezes, para explicar aos professores as causas do insucesso escolar de muitas crianças portuguesas imigrantes. (DNA, $\left.\mathrm{n}^{\circ} 177,22 / 04 / 00\right)$.

b. ...Eduardo Gageiro entregou todo o seu talento ao jornalismo.(DNA, $\left.\mathrm{n}^{\mathrm{o}} 166,05 / 02 / 00\right)$.

\footnotetext{
${ }^{22}$ Exemplos renumerados.
} 


\section{c. DIREITO À DIFERENÇA. 60 MODELOS DIFERENTES, 9000} VIATURAS E MAIS DE 200000 CLIENTES.Dos mais económicos aos mais executivos, oferecemos aos nossos clientes sempre a melhor qualidade, com a garantia da EUROPCAR. Europcar | MUITO MAIS DO QUE ALUGAR UM AUTOMÓVEL. (Visão,n $\left.{ }^{0} 342,30 / 09 / 99\right)$.

d. A pele do seu bebé é muito delicada e o seu rabinho é uma das zonas mais sensíveis do seu corpo. Ao estar permanentemente exposto à humidade e a outros agentes externos, é fundamental dedicar-lhe toda a atenção, oferecendo-lhe uma fralda com Cermo- protecção e Máxima Secura. (Pais \& Filhos, nº 105, 10/10/ 1999)

No PB, ocorre variação no uso da preposição $a$ e para com os OIs. No entanto, na expressão anafórica da função destaca-se um fato marcante: a substituição do clítico the/lhes pelas formas pronominais introduzidas por preposições: preposicionadas a/para elelela/eles/elas, sem o redobro, tanto nos anúncios (34a), como nas entrevistas (34b) $(34 c)-(34 d)$ e reportagens $(34 \mathrm{e})-(34 \mathrm{f}):^{23}$

(34) a. Se o seu namorado merece mais do que rosas, dê para ele os melhores botões. Camisas Dudalina por Fernando de Barros. (Cláudia, 06/04/1999).

b. ...o mesmo respeito que merecem os professores de seus alunos, que dão $a$ eles, lamentavelmente, um péssimo exemplo. (Veja, 08/03/00).

c. Segundo seu relato, um empresário do setor de ônibus contou a ele ter sido obrigado a aceitar um acordo para pagar 40.000 reais por mês. (Veja, 26/06/2002).

d. Em julho de 1980, o papa visitou o Rio Grande do Sul. Na oportunidade, eu era o presidente da Câmara Municipal de Porto Alegre e entregueia ele o título de cidadão porto-alegrense. (Veja, 26/06/2002).

e. Das biografias de Lula, minha predileta é a de seu mentor intelectual, Frei Betto. Se me nomeassem diretor da Eletrobrás, eudaria a ele a função de escrever um roteiro sobre o presidente. (Veja, 28/5/2003).

f. Expliquei $a$ ele que a linguagem da televisão mudou nos últimos anos. E tentei convencê-lo de que as cenas não eram assim tão explícitas. (Veja, 28/5/2003).

\footnotetext{
${ }^{23}$ Exemplos renumerados.
} 
No PE o emprego das formas preposicionadas está condicionado por certas restrições, entre elas, o redobro do clítico (35a) ou a interpretação contrastiva/enfática $(35 b):^{24}$

(35) a. Enviei-lhe o livro a ele (não a seu irmão).

b. Darei a notícia só a ele.

As autoras mostram que as similaridades e as diferenças entre o PE e o PB, com respeito ao emprego dos pronomes anafóricos de $3^{\mathrm{a}}$ pessoa, pode ser expresso no paradigma em (36). ${ }^{25}$ Observe-se que o verbo reagir, diferentemente de dar, seleciona um complemento preposicionado em ambas as variedades.

(36) a. O José reagiu a ele.(PE/PB)

b. O José deu a ele o livro. (*PE/PB)

c. O José deu-lhe a ele o livro. (PE/*PB)

d. O José deu-lhe o livro. (PE/PB formal)

Assim, fica claro os resultados da análise desses textos escritos vêm ao encontro do que já se havia observado na fala.

As autoras empreendem ainda uma outra tarefa: verificar se essas tendências se manifestavam em textos de natureza semiformal. Para tanto, analisam dados colhidos em sessões de debate do Fórum de Debates do Estado de São Paulo - On-line, entre 2003 e 2004. Os resultados publicados em Torres Morais \& Berlinck (2007) mostram que 5\% dos objetos dativos foram expressos por meio de um pronome clítico (37); 11\% na forma de pronome lexical (Preposição + pronome) (38a) - (38b) e 41,5\% como objeto nulo $(39) .^{26}$

(37) Waltinho auau... não fique estressado assim, pode lhe fazer mal. Apenas disse para ve não copiar artigos do jornal local para impressionar os demais leitores, sugiro que procure o tal jornal e peça lhes um forum exclusivo...

\footnotetext{
${ }^{24}$ Exemplos renumerados.

${ }^{25}$ Exemplos renumerados.

${ }^{26}$ Exemplos renumerados.
} 
(38) a. Brasileiros, este País é nosso. Não vamos permitir que estes ratos políticos tipo ACM, Arruda, Marta, Quércia, Maluf, inescrupulosos tirem uma com a nossa cara. Vamos mostrara eles que não temos porque respeitá-los pois nunca tiveram respeito por nós. Vamos dar um basta nisso. Chega!! Malditos... Saiam de nossas casas, e nossas vidas, deixem-nos em paz!!!!

b. Eu concordo com a atitude tomada pelo juiz brasileiro, pois devemos mostrar aos USA, que somos capazes também de exercer o nosso direito diante de atitudes como esta. Caso os americanos boicotem nossos produtos devemos tb evitar os seus produtos, mostrando para eles que somos um povo forte e unido.

(39) A mídia está noticiando a nossa participação no Haiti. Já mandamos medicamentos__ já mandamos tropas _ e, agora, estamos prestes a fazer empréstimo de 50 milhões de dólares. Como contribuinte, eu pergunto: se temos dinheiro para emprestar, por que estamos endividados até o pescoço com o FMI?

Segundo as pesquisadoras, a presença de formas variáveis em textos escritos é um indício forte de que se está numa fase avançada de implementação.

Com relação à substituição da preposição $a$ pela preposição para ou de com os verbos bitransitivos com OI meta/alvo ou fonte/origem, Torres Morais \& Berlinck (2007) ressaltam as diferenças existentes, segundo o papel temático expresso. Quando o argumento expressa fonte/origem, a alternância fica entre as preposições $a$ e $d e$, como é o caso também no PE. No entanto, a construção com $a$ ocorre marginalmente no PB atual.

Já no caso do argumento meta/alvo, as autoras mostram que o emprego de $a$ é possível e sua frequência varia segundo a origem geográfica do informante. No entanto, aqui também há predomínio de para. O gráfico abaixo, revela o declínio da preposição $a$ a partir do século XX nos corpora de anúncios e cartas de leitores e redatores: ${ }^{27}$

\footnotetext{
${ }^{27}$ Gráfico renumerado.
} 


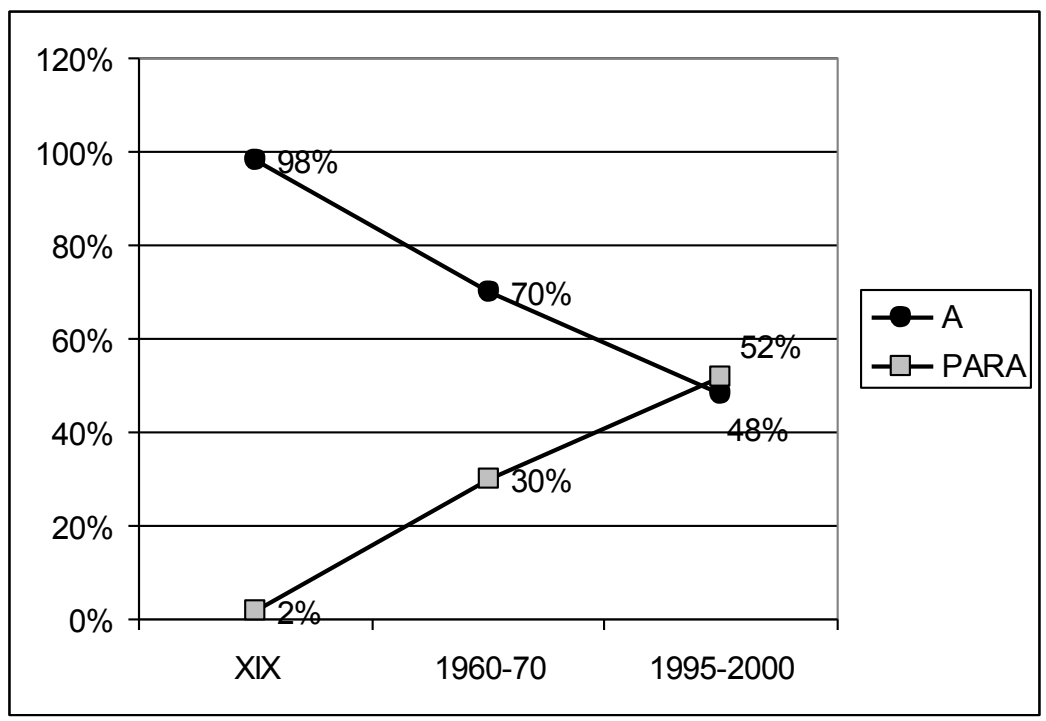

Gráfico 1. Emprego das preposições a / para na expressão do dativo, em corpora de anúncios e cartas de leitores/redatores

As autoras afirmam que os resultados obtidos revelam um equilíbrio na alternância entre as preposições, no período de 1995-2000. O que se pode concluir é que a escrita já está refletindo o processo de substituição de a por para, embora a primeira ainda esteja bastante presente nessa modalidade.

Outro aspecto destacado no texto é o que se refere tipo de verbo ao qual o argumento dativo se associa. Na análise de dados do Fórum de Debates do Estado de São Paulo On-line, o uso da preposição $a$ ( $82 \%$ das ocorrências) prevalece com os verbos de transferência verbal/perceptual. Já com verbos de transferência material e de movimento, o índice do uso de $a$ fica em torno de $67 \%$. Também para esse caso, as pesquisadoras lembram que as fontes dessa análise são textos de natureza semiformal.

\subsubsection{Uma proposta teórica para o OI no PE e PB}

Em Torres Morais \& Berlinck $(2007,2009)$ encontramos uma proposta de análise do OI dentro de um quadro formal mais elaborado que envolve uma perspectiva comparativa entre o PE e o PB. Tomando como ponto de partida o conhecido fenômeno da "alternância dativa", já estudado exaustivamente para o inglês e, mais recentemente, em várias outras línguas, entre elas, o grego, o espanhol, o japonês, o alemão, defende-se a hipótese de que o PE apresenta a alternância dativa, no contexto dos verbos de 
transferência e movimento, e no contexto dos verbos de criação, como pintar, desenhar, preparar, bater /assar (um bolo), etc. Vejamos a ilustração do fenômeno no PE: ${ }^{28}$

(40) a. O José enviou uma carta ao Pedro/enviou-lhe uma carta.

b. O José enviou uma carta para o Pedro/para Lisboa.

(41) a. O José roubou o relógio ao Pedro/roubou-lhe o relógio.

b. O José roubou o relógio do Pedro.

(42) a. O José preparou um delicioso jantar à Maria/ preparou-lhe um jantar.

b. O José preparou um delicioso jantar para a Maria.

Observe-se que, para os falantes portugueses, embora os argumentos sujeito e OD não apresentem nenhuma alteração de natureza morfológica ou semântica, o OI tem aspectos morfológicos, sintáticos e semânticos distintos.

As pesquisadoras propõem que a distinção morfossintática pode ser entendida nos seguintes termos: nas sentenças em (40a) - (41a) - (42a), o OI é um Sintagma Determinante (SD), uma vez que a preposição $a$ é um marcador de caso dativo. Da mesma forma, na realização pronominal, os clíticos lhe/lhes são dativos. Em (40b) - (41b) - (42b), ao contrário, o OI é um Sintagma Preposicionado (SP), um objeto/complemento oblíquo, sendo introduzido por uma preposição com conteúdo lexical.

A distinção morfológica que caracteriza a alternância no PE tem ainda um efeito semântico. A estrutura preposicionada com verbos como dar, enviar, entregar, levar, mandar, fazer, preparar, só é possível nos casos em que se pode obter a interpretação do OI como locativo/meta/beneficiário.

No caso da variante dativa, o OI é interpretado como recipiente, no sentido em que se estabelece uma relação direta de posse entre o OD-tema e OI. Daí decorre o fato de que um argumento locativo puro como Lisboa não possa ser pronominalizado por the. Locativos puros não podem ser interpretados como recipientes.

\footnotetext{
${ }^{28}$ Exemplos renumerados.
} 
Do mesmo modo, com verbos como furtar, roubar, etc. o OI dativo é interpretado como fonte/origem (41a). Na variante dativa, o objeto roubado é entendido como estando na posse do indivíduo no momento do roubo.

No caso da variante preposicionada há uma interpretação ambígua entre genitivo e oblíquo. No caso da interpretação genitiva, o SP do Pedro é gerado dentro do SD-OD, atuando como complemento nominal.

No caso da interpretação oblíqua, o SP do Pedro é interpretado como possuidor direcional do movimento, e gerado como um complemento do verbo.

Com os verbos de criação, o OI é beneficiário em ambas as variantes. Entretanto, no caso da variante dativa o OI é entendido como o recipiente do OD. No caso da variante preposicionado, a interpretação do OI está construída pela presença da preposição direcional para.

A distinção dativo/oblíquo revela ainda diferentes estruturas sintáticas. Seguindo a teoria dos núcleos aplicativos baixos e altos como introdutores de argumentos, proposta em Pylkkanen (2002) (apud Torres Morais \& Berlinck 2007, 2009), e aplicada ao espanhol por Cuervo (2003) (apud Torres Morais \& Berlinck 2007), Torres Morais \& Berlinck $(2007,2009)$ assumem que, no PE, a variante dativa projeta uma configuração aplicativa, como se mostra na Figura 7 abaixo. Já a estrutura preposicionada está projetada na Figura $8 .{ }^{29}$

$\mathrm{Na}$ estrutura aplicativa, o núcleo aplicativo, gerado abaixo do SV, toma um SDtema como seu complemento e o relaciona ao SD-OI licenciado em seu especificador. Por fim, a frase aplicativa combina com o verbo. O núcleo aplicativo denota uma relação dinâmica de transferência de posse em que o SD mais alto se relaciona ao SD-tema mais baixo. Na variante preposicionada o OI é um SP, ou complemento oblíquo, introduzido por uma preposição transitiva, lexical.

\footnotetext{
${ }^{29}$ Figuras renumeradas.
} 
Figura 7. Estrutura aplicativa

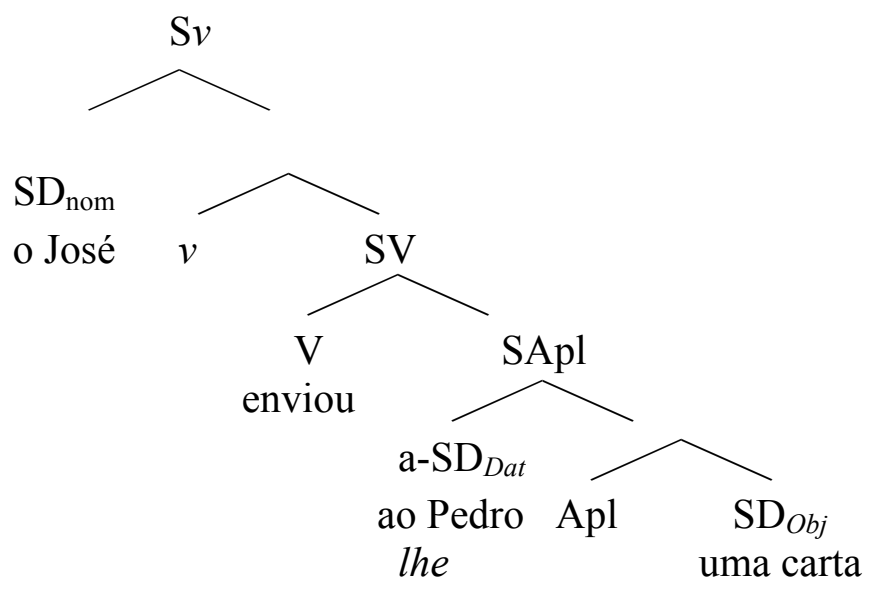

Figura 8. Estrutura preposicionada

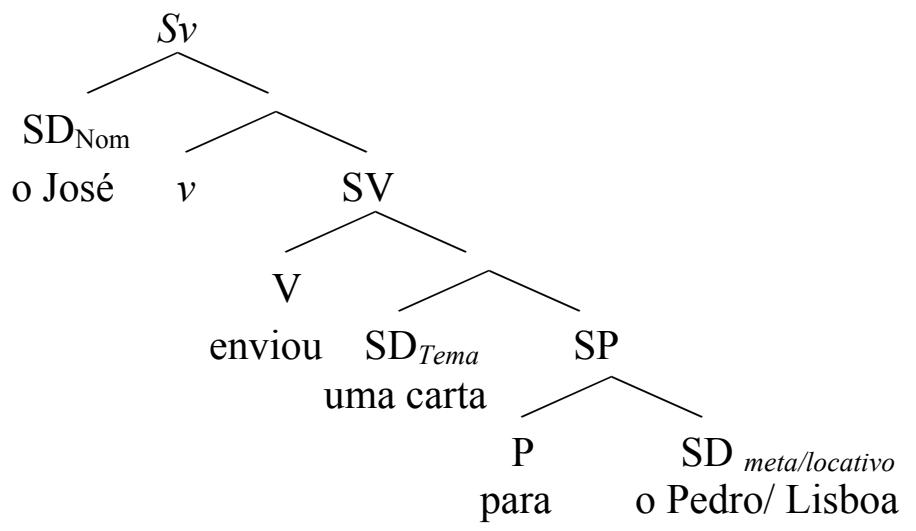

As pesquisadoras assumem ainda que essa abordagem permite dar conta dos rumos distintos que o PE e PB tomaram neste aspecto de sua gramática. A reanálise relevante que se manifesta no PB é a perda da propriedade gramatical de expressar morfologicamente o OI. Com isso, o PB deixa de selecionar do inventário dos núcleos funcionais, introdutores de argumentos, o núcleo aplicativo, que introduz o argumento dativo. O OI dativo é agora um OI oblíquo, um SP, tanto nos casos em que se apresenta 
realizado como um item lexical pleno, quanto nos casos em que é uma forma pronominal forte.

Vale ressaltar que a semântica dos OIs expressa pela estrutura aplicativa é incorporada na estrutura preposicionada do PB. As preposições, a, para e de podem ser ambíguas na expressão dos diferentes papéis temáticos, incorporando os sentidos de recipiente/meta/locativo/beneficiário/fonte.

Na mesma linha, Torres Morais \& Salles (2010) apresentam novos argumentos para a hipótese de que a variação interlinguística aqui descrita resulta de uma mudança paramétrica, definida como perda do núcleo aplicativo no PB. Segundo as pesquisadoras, a conexão entre Caso dativo e expressão de parâmetros sustenta a teoria dos Princípios e Parâmetros, uma vez que evidencia o fato de que a variação paramétrica é determinada no léxico, em termos dos traços das categorias funcionais..

Enquanto manteve o seu sistema de caso morfológico, em que os pronomes nominativos, acusativos e dativos estavam bem distintos, foi possível às crianças, no processo de aquisição do PB, terem evidências positivas para a construção aplicativa, uma vez que o OI exibia, tanto na sua forma lexical, quanto pronominal, a morfologia dativa.

Com base em Roberts (2007) as autoras assumem que à medida que o sistema pronominal se desestrutura e elege outras estratégias para expressão dos complementos acusativos e dativos, o traço DAT, gerado n núcleo aplicativo, que deve ser expresso morfologicamente, deixa de ser ativo na gramática do $\mathrm{PB}$, em oposição ao PE e PB histórico. Assumindo que os parâmetros são expressos lexicalmente nos traços formais das categorias funcionais, propõe-se que a perda da codificação dos dativos como uma classe morfologicamente distinta, significa a perda do traço DAT do núcleo aplicativo.

A reanálise morfológica atinge também a preposição $a$ como marcador dativo. Como a pesquisa nesta área tem revelado, ambas as mudanças ocorrem paralelas no percurso histórico do $\mathrm{PB}$.

O percurso histórico dos verbos de movimento e transferência revela que a configuração preposicionada se afirma, à medida que o OI é realizado como um complemento de preposição, ou seja, um complemento oblíquo, introduzido por preposições lexicais (a/para). 
1.5 Outros estudos comparativos do PE e PB

Estudos como de Freire (2000) e Bispo (2004) apresentam também resultados significativos com relação às estratégias de realização do OI nas duas variedades do português.

Primeiramente, o estudo de Freire (2000) analisou dados de língua falada culta do PB e do PE, selecionando duas amostras: a primeira, cedida pelo projeto NURC do Rio de Janeiro e conhecida como Recontato, é constituída da fala de 12 informantes com nível superior, entrevistados em 1992, e distribuídos em três faixas etárias, para documentar o PB.

A segunda amostra, oriunda dos inquéritos transcritos em Nascimento et al. (1987), compõe-se da fala de 28 informantes portugueses com curso universitário, entrevistados nos anos 70, também distribuídos em três faixas etárias, para descrever o PE. Comparando o quadro delineado para essas duas variedades, o autor observou que o mesmo processo não parece estar em curso no $\mathrm{PB}$ e no $\mathrm{PE}$.

Para ilustrar as variantes na realização do dativo anafórico, Freire (2000) apresenta a tabela a seguir com os seguintes resultados ${ }^{30}$ :

\begin{tabular}{|c|c|c|c|c|c|c|c|c|c|c|}
\hline Variante & \multicolumn{2}{|c|}{ Clítico } & \multicolumn{2}{|l|}{ Pron. Lexical } & \multicolumn{2}{|c|}{ SN anafórico } & \multicolumn{2}{|c|}{ Dativo nulo } & \multicolumn{2}{|c|}{ Total } \\
\hline Variedade & N. $^{\text {o }}$ & $\%$ & N. $^{\text {o }}$ & $\%$ & N. $^{\text {o }}$ & $\%$ & N. $^{\text {o }}$ & $\%$ & N. $^{\text {o }}$ & $\%$ \\
\hline PB & - & - & 8 & 57 & 1 & 7 & 5 & 36 & 14 & 100 \\
\hline PE & 29 & 88 & - & - & 1 & 3 & 3 & 9 & 33 & 100 \\
\hline
\end{tabular}

Tabela 5. Distribuição dos dados computados segundo a variante usada

Os resultados mostram que a fala padrão lusitana faz largo uso do clítico lhe na realização do dativo de terceira pessoa. Ao contrário, a fala culta brasileira não registra um só uso dessa variante. Assim, as estratégias de substituição ao clítico dativo são muito

\footnotetext{
${ }^{30}$ Tabela renumerada.
} 
mais frequentes na variedade brasileira do que na europeia. Por fim, vê-se que o pronome lexical é a estratégia preferida no $\mathrm{P}$, embora ausente no PE.

Freire nota ainda que, embora as duas variedades do português empreguem SNs anafóricos e objetos nulos, há uma diferença considerável no emprego dessas variantes, já que se mostram mais forte no PB do que no PE. Freire investigou, também, a frequência do clítico dativo lhe quanto à pessoa gramatical nas duas variedades. A tabela seguinte apresenta seus resultados ${ }^{31}$ :

\begin{tabular}{|c|c|c|c|c|}
\hline Pessoa gramatical & \multicolumn{2}{|c|}{ Segunda pessoa } & \multicolumn{2}{c|}{ Terceira pessoa } \\
\hline Variedade & N. $^{0}$ & $\%$ & N. $^{\circ}$ & $\%$ \\
\hline Português Brasileiro & $2 / 2$ & 100 & - & - \\
\hline Português Europeu & $2 / 31$ & 6 & $29 / 31$ & 94 \\
\hline
\end{tabular}

Tabela 6. Distribuição do clítico lhe segundo a pessoa gramatical

Vê-se que, na referência à terceira pessoa, o clítico lhe se mostra completamente ausente, e, mesmo na referência à segunda pessoa, o seu emprego é insignificante, visto que só foram encontradas duas ocorrências uma em função acusativa e uma como dativo.

A partir da amostra analisada para o PE, constata-se que o clítico lhe apresenta um escasso uso na referência à segunda pessoa em oposição à alta produtividade que apresenta na referência à terceira pessoa, diferentemente da variedade brasileira.

Como Freire comenta, é comum atribuir-se o fato acima descrito sobre o PB a um fenômeno que vem se registrando em grande parte do território brasileiro: o uso do pronome você como forma de tratamento de segunda pessoa em lugar de $t u$, o que licenciaria o emprego do clítico lhe, tanto em função acusativa como dativa, na referência à segunda pessoa e explicaria a sua quase ou completa ausência na representação do dativo de terceira pessoa.

\footnotetext{
${ }^{31}$ Tabela renumerada.
} 
Como dissemos, outro aspecto em que as duas variedades do português diferem é relativo à preposição a e para. Também isso é abordado no estudo de Freire. Destacamos os casos do uso anafórico dos pronomes. Vejamos os resultados encontrados por ele ${ }^{32}$.

\begin{tabular}{|c|c|c|c|c|}
\hline PREPOSIÇÃO & \multicolumn{2}{|c|}{ A } & \multicolumn{2}{c|}{ PARA } \\
\hline PB & N. ${ }^{0}$ & $\%$ & N. $^{\circ}$ & $\%$ \\
\hline Pronome lexical & $5 / 8$ & 63 & $3 / 8$ & 37 \\
\hline SN anafórico & - & - & $1 / 1$ & 100 \\
\hline PREPOSIÇÃO & \multicolumn{2}{|c|}{$\mathrm{A}$} & \multicolumn{2}{c|}{ PARA } \\
\hline PE & N. ${ }^{0}$ & $\%$ & $\mathrm{~N}^{\circ}$ & $\%$ \\
\hline SN anafórico & $1 / 1$ & 100 & - & - \\
\hline
\end{tabular}

Tabela 7. Distribuição das variantes tônicas segundo a preposição regente

Através da tabela acima, Freire verificou que, no PB, a preposição $a$ se mostra bem frequente regendo os dativos anafóricos representados pelo pronome lexical totalizando $63 \%$ das ocorrências, o que constitui uma característica da fala culta. No entanto, ainda é alto o uso da preposição para, com um índice de 37\% de ocorrência com os pronomes lexicais. Houve uma única ocorrência de SN anafórico na representação do dativo anafórico de terceira pessoa. Vejamos os exemplos em $(43)^{33}$ :

(43) a. Eu não tive coragem nem de deixar a babá ficar do lado de fora, tinha medo que acontecesse alguma coisa a ela.

b. Essas meninas que são super presas e tal, a mãe delas é de Fortaleza [...] eu falo pra ela: "Pô, é um absurdo você não deixar as suas filhas atravessarem a rua pra ir no colégio!"

c. Minha filha, nem se fala né, muito vaidosa, tá sempre reclamando da mãe, às vezes ela pede pra mãe escolher uma roupa pra ela, porque ela tá na casa da avó.

\footnotetext{
32 Tabela renumerada.

${ }^{33}$ Exemplos renumerados.
} 
Ao estudar a substituição dos clíticos por formas alternativas, Freire verificou ainda que o traço [+/-humano] do objeto mostra-se bastante significativo na escolha da variante candidata à representação do objeto anafórico na fala culta do Brasil e de Portugal.

Segundo esse estudo, no PB, quando o antecedente do dativo apresenta o traço [+animado], há uma concorrência entre as variantes do dativo anafórico de terceira pessoa (clítico, pronome lexical e SN anafórico). No entanto, nota-se a vantagem do pronome lexical (62\%) sobre as demais estratégias. Por outro lado, o traço [-animado] desse antecedente, uma única ocorrência, favorece o emprego do dativo nulo (100\%), um comportamento semelhante ao do objeto nulo na função acusativa.

A respeito do PE, Freire constata que o traço [+animado] do antecedente do dativo favorece uma diversidade de variantes na realização do dativo anafórico, com o predomínio do clítico (85\%). Com o traço [-animado] desse antecedente, só houve ocorrências do clítico, o que mostra a rejeição de formas tônicas com referentes [animados] no PE.

A conclusão a que chega o pesquisador, a partir dos resultados obtidos, pode ser descrita nos seguintes termos: no $\mathrm{PE}$, ao contrário do $\mathrm{PB}$, o emprego do pronome clítico não decorre da escolarização. Ao contrário, no $\mathrm{PB}$, a variante pronome clítico é uma forma de realização do dativo adquirida via escolarização, tendo seu uso condicionado pelos contextos situacionais, associados a graus de maior letramento e formalidade.

Outro estudo que estuda a codificação do dativo no PB em contraste com o PE é o de Bispo (2004). A linguista analisa dados coletados em um corpus constituído a partir de entrevistas de falantes do PE, originários de diferentes distritos de Portugal e de falantes do PB, oriundos das cidades do Rio de Janeiro e de João Pessoa.

Bispo observa os seguintes resultados totais, comparando-se o PB com o PE: perda do clítico dativo (43\%) e aumento do sintagma preposicionado (57\%) no PB. O percentual da preposição $a$ no $\mathrm{PE}(13 \%)$ apresenta diferença pequena em relação ao percentual dessa preposição no PB (11\%). Entretanto, no que diz respeito ao percentual da preposição para, verifica-se diferença bastante significativa, quando comparados os resultados das duas variedades. 
A preposição para não é encontrada no PE, quando introdutora de dativo, mas apresenta percentual de $46 \%$ no PB. A autora observa ainda que no PB, o clítico de $3^{\mathrm{a}}$ pessoa está desaparecendo e está aumentando o uso de dativo introduzido por para na $3^{\text {a }}$ pessoa.

Conforme o estudo de Bispo, não foi encontrado o fenômeno de redobro do clítico no PB atual. O redobro do clítico é encontrado somente no PE e em línguas como o espanhol, embora com diferenças importantes: no PE o redobro se manifesta apenas se o OI é uma forma pronominal forte, introduzida pela preposição $a$ - "Dei-lhe o livro $a$ ela". No Espanhol o redobro ocorre na presença do SD-OI - "Le compró um piso a su hijo".

Analisando os exemplos de Bispo não se encontra o uso da preposição para como introdutora de OI no PE, sendo a preposição $a$ categórica nesses contextos. Os casos em que a preposição para foi encontrada referem-se às construções com funções oblíquas. $\mathrm{O}$ $\mathrm{PB}$, além de apresentar a variação entre a preposição $a$ e para, evidencia variação entre a pronominalização com o clítico e com a forma pronominal introduzida pela preposição.

\subsection{Proposta de análise}

Como foi enfatizado nas seções anteriores, o OI nulo tem sido considerado uma estratégia produtiva na substituição dos clíticos dativos de $3^{\mathrm{a}}$ pessoa. Torres Morais (2010), porém, apresenta uma reflexão um pouco diferente sobre essa estratégia, numa perspectiva comparativa entre o PB e o PE.

Torres Morais parte da observação de que o OI nulo de $3^{\mathrm{a}}$ pessoa, embora licenciado tanto no PE como no PB, tem uma produtividade muito maior na variedade brasileira. Tal fato parece relacionar-se à baixa ocorrência dos clíticos dativos no PB. No entanto, Torres Morais argumenta que esta pode não ser uma relação direta: a variante inovadora pode não ser o OI nulo, mas o pronome forte, introduzido por preposição.

De fato, vários estudos têm revelado que os contextos que favorecem o uso da forma nula são os que apresentam verbos dicendi. Ora, como se sabe, o apagamento dos OIs no contexto desses verbos, parece e ser um fenômeno universal. 
Assim, seria necessária uma investigação mais rigorosa, tanto para o avanço das formas preposicionadas anafóricas a/para ele(s); a/para ela(s),como para as formas nulas, no PB.

Uma das hipóteses levantadas por Torres Morais é a de que o PE pertenceria ao rol das línguas que não permitem OIs nulos. A evidência é de natureza empírica e teórica.

A evidência empírica consiste na sua baixa frequência, a qual pode estar ligada ao fato de que os OIs no PE estão praticamente restritos aos verbos dicendi.

Pode-se inferir, portanto, que o OI nulo no contexto dos verbos dicendi, embora apresentem um uso anafórico, condicionado pela presença de um antecedente recuperado no contexto linguístico, podem ser tratados como argumento implícito.

Porém, como a autora nota, há um problema com esta suposição: alguns informantes portugueses aceitam o par alternante ilustrado em (44a) - (44b) ${ }^{34}$ :

(44) a. Não fui ao casamento da Maria, mas dei-lhe um presente.

b. Não fui ao casamento da Maria, mas dei _ um presente.

No entanto, como a autora enfatiza, pode ser que a intuição linguística não seja tão efetiva, uma vez que Freire $(2000,2005)$ não encontrou nenhum caso de OI nulo no PE fora do contexto dos verbos dicendi.

Quanto à evidência teórica para a ausência de OI nulo no PE, Torres Morais afirma que a mesma resulta da hipótese de que os OIs dativos são introduzidos por um núcleo aplicativo. A autora defende a ideia de que a Construção de Objeto Duplo, presente em línguas como inglês e espanhol, é uma estrutura aplicativa. Em ambas as línguas, por diferentes razões, o OI não pode ser nulo.

O espanhol é interessante, uma vez que vários autores consideram o redobro obrigatório do clítico dativo nas bitransitivas desta língua como marca identificadora da referida construção. Em particular, Cuervo (2003) (apud Torres Morais \& Berlinck 2007) afirma que o clítico dativo lexicaliza o núcleo aplicativo.

Torres Morais (2010) propõe que, também no PE, a ausência do OI nulo dativo decorreria da natureza da frase aplicativa. Assim, os OIs nulos, com os verbos dicendi,

\footnotetext{
${ }^{34}$ Exemplos renumerados.
} 
podem ser analisados como argumentos implícitos numa estrutura preposicionada, mas não numa estrutura aplicativa.

Como se discutiu na seção 1.4.1.4, no PB há perda da codificação morfológica do OI, evidenciada pela substituição da preposição $a$ por para e decréscimo no uso dos clíticos dativos lhe(s), os quais são substituídos por diferentes estratégias de pronominalização: pronome lexical dentro da frase preposicional e OI nulo fonologicamente.

Dentro da teoria dos núcleos aplicativos, a conclusão é a de que o PB codifica o OI de $3^{\text {a }}$ pessoa unicamente como função oblíqua. Ora, se o OI nulo deve ser reconhecido como uma das variantes inovadoras ao uso dos clíticos, e se o PB perde o núcleo aplicativo como introdutor de OI, a hipótese que decorre é a de que o OI nulo anafórico reflete um caso de elipse de Sintagma Preposicionado.

Nesta dissertação, a proposta que apresentamos para dar conta do PB é a de que a configuração bitransitiva preposicionada, como expressa parcialmente na Figura 9, é projetada no contexto dos verbos em que ocorrem dois complementos, um OD e um OI. No caso do OI de $3^{\text {a }}$ pessoa, a mesma configuração se aplica ao OI lexical e pronominal.

Figura 9. Estrutura preposicionada do PB

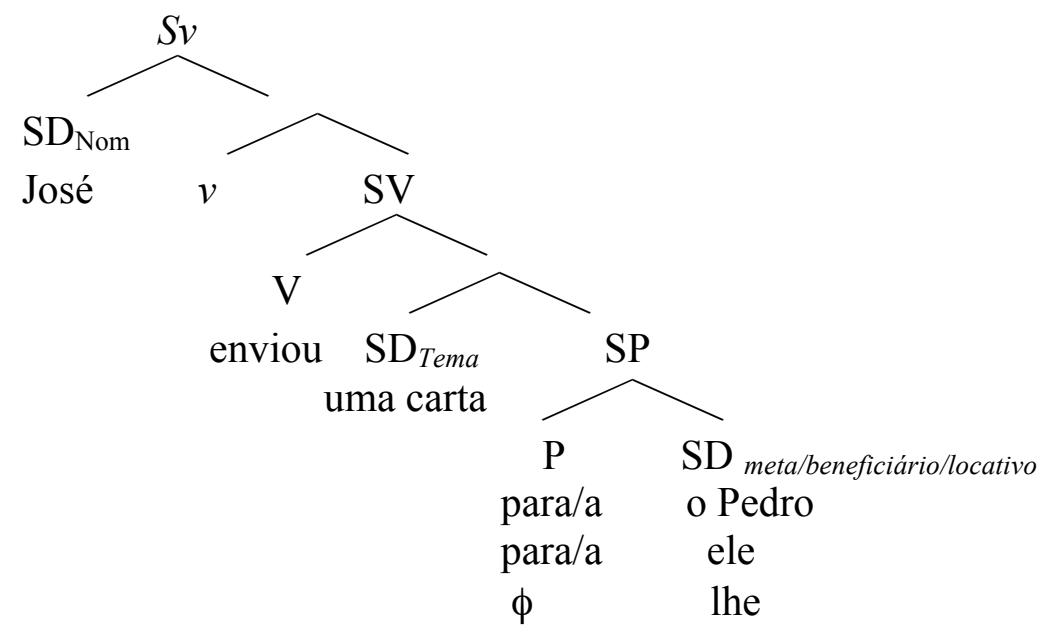

Portanto, os clíticos de $3^{\mathrm{a}}$ pessoa, adquiridos na escolaridade são gerados na mesma posição do OI pronominal, introduzido por preposição e OI lexical. A diferença está em que, com a forma clítica, o núcleo preposicionado não está realizado 
lexicalmente. Posteriormente, por restrição de natureza fonológica, o clítico se move para a posição funcional mais alta ocupada pelo verbo.

Concluindo este capítulo, pensamos ter deixado claro que as mudanças que ocorrem na expressão do $\mathrm{OI}$ no $\mathrm{PB}$, caracterizada como uma mudança de natureza paramétrica, nos leva a concluir que, nesta língua, o OI é um complemento oblíquo, ou seja, introduzido por preposição lexical. No $\mathrm{PE}$, ao contrário, o OI é morfologicamente expresso por marcas casuais de dativo. Nestes termos, é realizado como um SD e introduzido na sintaxe por um núcleo aplicativo. 


\section{CAPÍTULO 2}

\section{Fundamentos teóricos e metodológicos}

Neste capítulo apresentamos o quadro teórico dentro do qual iremos descrever um caso de mudança no PB. Como mostramos no capítulo 1, essa variedade parece estar em processo de perder um uso plenamente produtivo do objeto indireto (OI), como uma classe identificada estruturalmente e morfologicamente. Ao contrário, o português europeu (PE) mostra todas as propriedades para identificar o OI como uma classe gramatical distinta dos complementos oblíquos, no contexto de um conjunto de verbos que expressam eventos dinâmicos.

Nosso objetivo principal é encontrar argumentos que justifiquem a hipótese de que a complexidade da mudança sintática pode ser melhor abordada se considerarmos a associação entre um modelo internalista, como o que caracteriza a Teoria dos Princípios e Parâmetros (P\&P), com um modelo que enfrenta as questões referentes aos aspectos externos ou dinâmicos da mudança sintática, como o que caracteriza a Teoria da Variação e Mudança Linguísticas.

Como esclarece Torres Morais \& Berlinck (2009), a abordagem paramétrica da Teoria dos P\&P fornece um aparato formal para análise e comparação dos sistemas gramaticais, e para as dimensões nas quais tais sistemas podem variar e mudar. A Teoria da Variação e Mudança Linguísticas, por sua vez, olha para os fatores referentes à forma como as mudanças se manifestam e se propagam nas comunidades de fala, entre eles, mudança gradual, transição, variação ordenada, competição de gramáticas, diglossia sintática, contato.

O segundo objetivo é apresentar a metodologia que adotamos para obtermos os resultados dos dados analisados. 
2.1 Abordagem paramétrica e mudança sintática

No quadro conceitual da gramática gerativa, defende-se a ideia da linguagem como faculdade inata e específica da mente humana. Assume-se um sistema cognitivo inato que faz parte da herança genética de qualquer pessoa, tornando-a capaz de adquirir uma língua complexa, rica e bem articulada a partir dos dados (input) a que é exposta.

A faculdade da linguagem (FL), também denominada Gramática Universal (GU), não é um sistema homogêneo, uma vez que interage de maneira complexa com outros módulos mentais também autônomos. Na mente de qualquer adulto, o referido sistema de natureza computacional responsável pela linguagem constitui o que se denomina LínguaI, ou gramática internalizada na mente/cérebro do falante nativo, em oposição ao seu estado inicial. $^{35}$

Sendo assim, a GU é o estágio inicial $\left(\mathrm{S}_{0}\right)$ de um falante que está adquirindo uma língua e o seu produto é o estágio final da aquisição, em outras palavras, o estágio em que a criança atinge a gramática adulta de sua língua $\left(\mathrm{S}_{\mathrm{S}}\right)$. Teríamos, assim, o seguinte esquema:

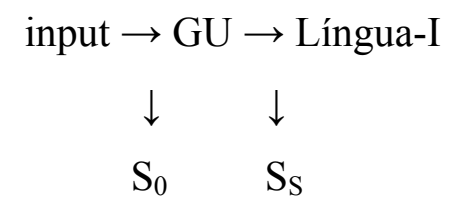

O objetivo da teoria linguística é desenvolver uma caracterização geral de uma gramática humana possível. Esta caracterização constitui uma reflexão sobre algum aspecto de como a mente funciona. Como a GU é geneticamente herdada, uma teoria que busca descrever a sua natureza é uma teoria que descreve um aspecto da realidade física. O termo GU é, portanto, ambíguo: refere-se tanto à teoria formulada pelo linguista, como a faculdade da linguagem instanciada na mente/cérebro dos falantes.

Observa-se que uma das propriedades universais das línguas humanas é a

\footnotetext{
${ }^{35} \mathrm{~A}$ Lingua-I(nterna) também entendida como competência linguística se opõe à Lingua-E(xterna), no sentido de desempenho linguístico.
} 
possibilidade de criar um número infinito de sentenças com um conjunto finito de elementos. A recursividade é a evidência do aspecto criativo do uso linguístico. O ser humano é capaz de produzir e entender um número de sentenças que não havia produzido ou ouvido antes. Esta propriedade faz parte da natureza humana da linguagem.

Outro universal linguístico, hoje consensual, é o de que as sentenças têm estrutura hierárquica, denominada estrutura de constituintes. As sentenças não são organizadas linearmente.

A formulação dos princípios que estruturam a GU, porém, é uma tarefa muito difícil. Basta pensar na diversidade linguística. Como é possível que um órgão genético, comum a todos os seres humanos, possa dar margem a tanta diversidade linguística, a qual envolve não apenas as diferentes línguas, mas os dialetos de uma mesma língua e até mesmo a língua de cada um?

Não é necessário ser linguista, nem letrado, para saber, inconscientemente, que as diferentes línguas têm diferentes gramáticas. Uma sentença bem formada em uma língua não é bem formada em outra. Assim, há diferenças na ordem das palavras, na expressão das categorias flexionais de número, gênero, caso, pessoa, no uso das formas pronominais, nos afixos, posposições, preposições, etc. Vários exemplos podem vir à mente de imediato. Ilustremos com dois deles.

No português europeu é obrigatório o uso do artigo definido antes dos possessivos. Tal regra é variável no PB:

(1) a. O meu computador não tem um bom teclado (PE/PB).

b. $\varnothing \mathrm{Meu}$ computador não tem um bom teclado (*PE/PB).

No inglês é possível mover um constituinte interrogativo sem a preposição que o introduz. No português está ausente tal propriedade gramatical:

(2) a. What are you talking about?

b. Sobre o que você está falando?

Como dar conta da variação linguística dentro de um modelo que supõe uma GU inata? 
Naturalmente, não se tem como sustentar a hipótese de que as diferenças seriam inatas, no seguinte sentido: japonês nasce programado para falar japonês. Alemão nasce com um tipo particular de $\mathrm{GU}$, etc. Com isso, as pessoas poderiam ter uma base para sustentar afirmações do tipo: "A sintaxe da minha a língua conta com artigos a sua não." Ou: "A gramática de minha língua tem muitos movimentos de constituintes para a periferia dos sintagmas nucleares, a sua quase não move nada.

Portanto, o cérebro dos falantes de minha língua é mais desenvolvido," e assim por diante. Se as diferenças sintáticas entre as línguas não são parte de seu componente genético, então elas não têm nada a ver com a GU? Seriam elas aleatórias?

Não foi essa, porém, a resposta dada para se entender a variação linguística, dentro do modelo gerativista.

A partir de Chosmky $(1981,1986)$, a GU foi formulada como um conjunto de universais linguísticos invariáveis e um conjunto de princípios com valores paramétricos, em aberto, a serem fixados nas diferentes línguas.

A variação sintática é determinada na própria teoria da $\mathrm{GU}$, através da noção de parâmetros de variação. Em outras palavras, dado um conjunto de princípios invariáveis, há um conjunto limitado de opções, especificadas pelos parâmetros, as quais serão fixadas pela criança, na fase da aquisição, com base na experiência linguística.

Tem sido assumido que variação paramétrica está restrita às categorias funcionais. Assim, na estruturação da sentença, as operações Concatenar, Mover e Concordar se diferenciam. Apenas concatenar é invariável. Mover e Concordar, porém, estão sujeitas à variação. Portanto, quando as reanálises ocorrem, os parâmetros relacionados aos traços formais das categorias funcionais envolvidas nas duas operações são os que mudam (cf. Roberts, 2007, para a discussão deste ponto).

Roberts (2007) formaliza a noção de parâmetros com base em três propriedades: (i) um conjunto de traços formais altamente restritos; (ii) a especificação de um valor default; (iii) a especificação das evidências que o expressem de forma clara na aquisição e mudança. Se a expressão de um parâmetro não é realizada de forma suficientemente robusta nos dados linguísticos primários, o parâmetro reverte para o seu valor default. 
2.2. A aquisição da linguagem e a variação sintática

Outra propriedade crucial da teoria do P\&P é a que os parâmetros são fixados pelas crianças, durante a fase da aquisição da linguagem, pelas crianças. Assim, Roberts (2007), partindo dos resultados de Guasti (2002), mostra que entre os dois e três anos as crianças já têm vários parâmetros da língua materna fixados. Recentemente, estudos de aquisição têm sido apresentados para o $\mathrm{PB}$ e $\mathrm{PE}$, mostrando que a criança é bem sucedida no final do processo que leva ao domínio da gramática núcleo dos indivíduos que fazem parte de sua comunidade de fala.

No entanto, se a criança é sempre bem sucedida na aquisição, e se a mudança linguística se dá durante esta fase, como resolver o impasse? Que as línguas mudam é um fato do qual ninguém duvida. Basta olhar os inúmeros trabalhos que editaram e analisaram textos produzidos na fase arcaica do português, por exemplo, para deparar com as estranhezas decorrentes de diferenças gramaticais, não apenas de natureza sintática, mas fonológica, morfológica, lexical.

Mas por que as línguas mudam? A mudança seria uma fatalidade? Seria inerente às línguas humanas?

Como mostra Roberts (2007, cap.3), a experiência linguística deve proporcionar pistas para a fixação dos parâmetros. Se essas pistas forem robustas o parâmetro será fixado corretamente e a criança terá sido bem sucedida na aquisição da sintaxe de sua língua materna. Segundo o autor, ambiguidade e opacidade na expressão de um parâmetro são requeridas para que as mudanças ocorram.

A opacidade é definida em termos de complexidade, uma vez que há um dispositivo de aquisição que leva a que representações estruturais mais simples, ou seja, com menos traços formais, sejam preferidas. Por sua vez, a expressão de parâmetro se torna ambígua, quando a estrutura expressa qualquer um dos seus valores, ou nenhum deles.

Mas por que as pistas mudariam? O autor afirma que toda mudança sintática deve ser causada. Uma das causas seria a própria natureza da transmissão das gramáticas dos falantes mais velhos para os mais novos. A criança pode fazer hipóteses que não levam à gramática da geração anterior em algum ponto. 
Como as gramáticas são entidades mentais, a criança não tem acesso direto à gramática internalizada (G1), na mente dos falantes com quem convive. A criança tem acesso unicamente ao corpus1produzido pela G1, e tem a faculdade inata da linguagem que a direciona nas hipóteses que pode fazer em relação ao corpus1. Não há uma ligação direta entre G1e a gramática internalizada pela criança $(\mathrm{G} 2)$.

A forma como as gramáticas são transmitidas, ou seja, através dos corpora, pode induzir a "erros", ou reanálises, que são manifestações de mudança no valor de, ao menos, um parâmetro. Entretanto, o modelo apresenta uma questão fundamental: se a G2 apresenta uma inovação no corpus 2 a inovação teve que ser ativada por algo no corpus 1 . Mas se este expressa a inovação, como poderá a G1produzir tal propriedade, sem que ela mesma a possua?

Como dissemos acima, Roberts afirma que, dentro deste cenário, há uma única resposta possível: a de que a mudança só ocorre se tiver uma causa.

Por sua vez, Kroch (2000) discute este ponto através do seguinte raciocínio: a causa da mudança tem que estar em dois pontos: em alguma mudança sutil no "input", ou em alguma diferença no indivíduo que adquire uma nova gramática, que pode ser o caso da aquisição de uma L2 por adultos, em situação de contato linguístico.

Como os fatores decorrentes e contato não podem ser os únicos que causam as mudanças, fatores gramaticais extra-sintáticos, ou seja, que estão em outra parte da gramática, na fonologia ou morfologia, podem alterar a expressão dos parâmetros nos dados linguísticos. Desta forma, a mudança linguística é, por definição, uma falha na transmissão de traços linguísticos através do tempo:

Under the imperfect transmission model, change begins with a change in grammar, and this grammatical change causes the frequencies with which certain linguistic forms are used to change, as the grammatical change propagates through the speech community. The change in grammar is caused by an inaccuracy in language transmission; that is, by mislearning. The mislearning may be by adult second-language learners, as in the case of certain kinds of language contact, or by children. The character of changes will be determined by the sorts of errors that learners are likely to make (Kroch, 2000 p. 1) 
Torna-se necessário, portanto, abandonar a idealização adotada na linguística gerativa sincrônica, segundo a qual a aquisição da linguagem é sempre bem sucedida. De fato, embora isso seja o que normalmente acontece, o autor afirma que é necessário reconhecer que o sucesso na aquisição é probabilístico. Erros ocorrerão com uma distribuição probabilística, dependendo da natureza das evidências nos dados primários.

Por que algumas vezes os erros persistem e finalmente propagam, sem serem corrigidos nas fases mais avançadas da aquisição? Kroch afirma que esta pergunta ainda não tem como ser respondida adequadamente.

Dentro deste cenário, o pressuposto gerativista de que a mudança ocorre na fase da aquisição levaria a uma importante hipótese: a de que os aprendizes fixam os parâmetros linguísticos de forma irreversível. Uma vez fixado, o parâmetro não será refixado. Se o parâmetro é fixado de acordo com o input linguístico, nada irá mudar. Entretanto, se certos dados não foram acessíveis, os erros irão acontecer e a criança terá fixado uma parâmetro que não corresponde ao da gramática do adulto.

O ponto interessante dessa reflexão de Kroch é o de que o aprendiz pode refixar o parâmetro, mas somente na forma de uma outra gramática. Não se trata de um tipo de variação em um única gramática, mas um tipo de variação que identifica dois dialetos.

Se ambos os parâmetros são evidenciados nos dados, como é o caso nos diferentes registros da língua, - um registro do vernáculo e outro da língua usada na escola -, então o falante irá aprender ambos os dialetos. Da mesma forma, se a mudança linguística está em progresso, o falante irá ouvir na comunidade de fala evidências de ambos os parâmetros, que, segundo Kroch, são inconsistentes entre si, e irá aprender ambos.

No percurso histórico ocorre algo ainda não muito claro: um dos parâmetros irá suplantar o outro. No entanto, para Kroch $(1989,2000$, 2001), o percurso no tempo mostra competição de gramáticas. $\mathrm{O}$ fato de que uma gramática gradualmente suplanta a outra pode ser medida pela frequência de uso de cada uma das formas.

O resultado da competição é que uma das formas passa a ocorrer numa frequência muito baixa, que não sustentar o aprendizado do parâmetro.

Assim, as gramáticas em competição nos dados históricos refletem registros estilísticos diferentes, dada a natureza conservadora da língua escrita. Nesses casos, entretanto, o vernáculo é a gramática vencedora. 
Portanto, esse modelo de mudança requer que se assumam duas características da aquisição da linguagem: primeira, que as crianças fazem erros na aquisição que levam tempo para serem corrigidos; segunda que os erros propagam de uma criança para a outra. ${ }^{36}$

In thinking about language change, however, we should be interested in a different feature of learner errors; namely, the possibility that they might be heard by other learners and treated by them as possible target forms. To the extent that learner errors are incompatible with universal grammar or other powerful constraints on adult language, such a development is, of course, impossible; but many learner errors are perfectly compatible with universal grammar, reflecting grammatical properties that hold of other languages, though not the target. If the evidence in the target language for the grammatical property at issue is weak, then there might be a significant probability of a child's error spreading to other members of his/her speech community. And if this error is common in child language, then the probability of it leading to language change might be substantial. (Kroch 2000.p. 26)

\subsection{Fatores externos da mudança sintática: a Teoria da Variação e Mudança Linguísticas}

Como Roberts (2007) discute, o modelo de mudança sintática proposto na Teoria dos P\&P considera dois pressupostos: (i) a mudança é instantânea: o valor de um parâmetro muda de forma súbita e decisiva. Ou seja, não é possível pensar em mudança gradual no valor de um parâmetro para outro (cf. Lightfoot, 1979, 1999); (ii) é interna ao falante, o que neutralizaria os fatores ambientais. O que importa são os dados linguísticos primários. Trata-se de um modelo internalista de mudança.

No entanto a Teoria da Variação e Mudança Linguísticas tem sistematizado a

\footnotetext{
${ }^{36}$ Kroch apresenta vários estudos de caso de aquisição de sintaxe em diferentes línguas, os quais mostram duas situações: a primeira, a de as crianças cometem erros na aquisição de um determinado fato gramatical de sua língua materna, que depois são corrigidos, embora umas levem mais tempo do que outras para corrigi-los. A segunda, a de que os erros não são corrigidos, como comentamos no texto acima. Também na aquisição, como na mudança, esta situação reflete competição de gramáticas.
} 
atuação dos fatores externos nos fenômenos de variação e mudança.

Ao desenvolver seu modelo de mudança, Weinreich, Labov, Herzog (1968), Labov $(1972,1994)$ propõem as cinco clássicas questões que se apresentam no estudo da mudança linguística:

1) Fatores condicionantes: fatores de natureza linguística e social favorecem ou desfavorecem determinada variantes durante o período de mudança. Uma das variantes sai vencedora num cenário de competição. Se uma das variantes é preferida em detrimento de outra, ocorre mudança. Os fatores de ordem linguística são os que se referem às propriedades internas das línguas, entre eles, os de natureza fonológica, morfológica, sintática, incluindo os de natureza semântica, pragmática e discursiva. Os de natureza social englobam os aspectos externos da mudança, entre eles, sexo, idade, classe, escolaridade, etc.

2) Transmissão: a mudança resulta de sua propagação na comunidade de fala. No entanto, enquanto há competição entre as variantes, a que estiver mais robusta, ou mais produtiva em termos percentuais, vai sendo a mais usada. A menos frequente se torna obsoleta com o tempo.

3) Encaixamento: as mudanças vão tendo um efeito de desdobramentos que afeta a estrutura linguística e social.

4) Avaliação: as variantes em competição são avaliadas pela comunidade de fala. Nesta avaliação uma das formas passa a ser rejeitada, impedindo ou dificultando a sua implementação, enquanto a outra vai sendo favorecida.

5) Implementação: há um período de instabilidade na fase da implementação até que uma das variantes passe a ser vitoriosa. Neste ponto acaba a fase de variação. A variante vitoriosa passa a ser a forma categórica.

Conclui-se, portanto, a partir do acima exposto, que a língua é vista como uma realidade heterogênea, mas sistematizada em sua organização. O percurso de uma mudança é lento e gradual e pressupõe períodos, por vezes longos, de convivência competitiva, entre as variantes que compõem a variável linguística.

Do que foi acima exposto fica a pergunta: como conciliar o modelo internalista com a teoria da variação e mudança linguísticas? 
2.4. Um olhar mais atento para a dinâmica da mudança.

Como acima comentado, Kroch (1989, 2000), embora assuma a noção de parâmetros, adota igualmente a noção de competição de gramáticas na propagação da mudança na comunidade de fala, que foram propostas na Teoria da Variação e Mudança Linguísticas.

Pode-se dizer que ainda que esses pressupostos são refinados quando se concilia, de forma original, a teoria paramétrica com um aparato matemático e logístico capaz de rastrear o percurso das formas linguísticas no tempo histórico.

$\mathrm{O}$ autor reconhece que a forma como as mudanças se manifestam nos dados parece contradizer a hipótese de que possam ser instantâneas. Nos seus estudos de caso, confirma-se que as mudanças paramétricas parecem seguir tipicamente uma Curva-S, ou seja, quando medida no curso do tempo, a nova forma é introduzida nos dados a partir de uma frequência muito baixa, ganha um aumento significativo nas percentagens e daí em diante continua num ritmo lento (cf. tb. Weinreich, Labov, Herzog 1968).

Ora, esse efeito gradual é impossível de ser concebido no processo de fixação dos parâmetros, durante a fase da aquisição da linguagem pela criança. Ele se refere, pois, à forma como a mudança se propaga na comunidade de fala.

Ao conciliar a natureza da aquisição das gramáticas com o seu percurso no tempo através da noção de gramáticas em competição, Kroch $(1989,2000)$ apresenta uma ideia original que pode descrita nos seguintes termos: quando uma opção gramatical substitui a outra com a qual está em competição, tanto no indivíduo, quanto na comunidade de fala, a taxa de substituição de uma opção pela outra é a mesma em todos os contextos linguísticos envolvidos.

Tal fenômeno denominado Efeito da Taxa Constante pode ser entendido, portanto, como a manifestação de uma mudança paramétrica.

Um outro ponto que pode ser levantado é o que se refere à questão de como a mudança paramétrica se propaga do indivíduo para a comunidade de fala (cf. Roberts, 2007, cap 4). Na tradição laboviana, a mudança linguística inicia-se quando um traço característico da variação na fala se difunde através de um subgrupo específico da comunidade de fala. 
Seguindo Roberts (2007) assumiremos que é possível conciliar o modelo internalista com a teoria variacionista que se ocupa dos aspectos externos relacionados com a dinâmica da mudança sintática. A abordagem paramétrica oferece o quadro teórico que trata das questões de como o falante atinge seu conhecimento linguístico e de como este conhecimento é adquirido.

O modelo internalista não trata das questões externas, relacionadas com a dinâmica da mudança sintática. Nestes termos, a Curva-S, competição de gramáticas, Efeito da Taxa Constante são fenômenos de natureza extra-gramatical. ${ }^{37}$

Também neste trabalho adotamos o mesmo quadro: de um lado, assumimos um valor paramétrico para a mudança em progresso na expressão do OI no PB; de outro buscamos traçar o seu percurso no tempo, os fatores que atuam na realização das variantes selecionadas.

Assumimos que o PB exibe atualmente um conjunto de variantes na realização da variável OI anafórico: clítico, pronome tônico, e categoria vazia. Essas variantes estão em competição/variação no sistema até que uma delas suplante as outras e passe a ser a forma definitiva, concluindo o processo de mudança.

\subsection{Metodologia}

A metodologia de análise dos dados deste estudo está embasada conforme o modelo de Teoria de Variação e Mudança. Resumidamente, escolhe-se uma variável dependente (sobre a qual se deseja depreender a mudança, aqui a realização do objeto indireto anafórico) e em seguida são determinadas as variáveis independentes linguísticas e extralinguísticas, se for o caso (aquelas que possivelmente exerçam influência sobre a variável dependente). Em seguida, os dados coletados foram submetidos à análise estatística do Programa Goldvarb para que fossem obtidos os percentuais de frequência das variantes.

\footnotetext{
${ }^{37} \mathrm{~A}$ adoção de perspectivas aparentemente conflituosas da variação e mudança linguísticas foi pioneiramente adotada por Tarallo \& Kato (1989) e, explorada em vários fenômenos que estão no estado de mudança em progresso no PB.
} 
Neste estudo, trabalharemos com três variantes do OI com interpretação anafórica (Berlinck 1997): clítico dativo lhe/te; preposição + pronome forte (a/para ele/ela; a/para você) e nulo. Tanto em contextos de $3^{\mathrm{a}}$ pessoa quanto de $2^{\mathrm{a}}$ pessoa.

Dentro do panorama desses dois quadros acima descritos, interessam particularmente à presente pesquisa os condicionamentos à realização das variantes focalizadas e as noções de implementação da mudança. Com relação à implementação, busca-se verificar quais são as estratégias de substituição do clítico e que caminhos percorrem no sistema do PB, levando-se em conta fatores estruturais e sociais.

Nas subseções que se seguem, apresentamos e justificamos a escolha das variáveis independentes (fatores) para, a partir dos resultados das variantes com os fatores, comprovar a ascensão do OI nulo e do pronome forte e a consequente queda do clítico.

A respeito do corpus deste estudo, a saber, peças de teatro dos séculos XIX e XX, será apresentado no próximo capítulo.

Para a análise quantitativa, como condicionantes, foram levados em conta dez grupos de fatores para a análise das realizações do OI, seis de natureza linguística e quatro de natureza extralinguística, arrolados a seguir:

\subsubsection{Fatores linguísticos}

1. Contextos verbais: dinâmico de transferência material (m)

dinâmico de transferência verbal / perceptual (v);

dinâmico de movimento físico (f);

dinâmico de movimento abstrato (e);

dinâmico de criação (n).

2. Papel temático: meta/alvo (r);

beneficiário (b).

3. Natureza semântica do OI: + animado + humano (k);

$$
+ \text { animado - humano (i); }
$$


- animado (o).

4. Pessoa gramatical: $2^{\mathrm{a}}$ pessoa (2);

$3^{\mathrm{a}}$ pessoa (3).

5. Clítico: lhe (1);

te $(\mathrm{t})$.

6. Preposição: a (a);

para (p).

2.5.2 Fatores extralinguísticos

7. Décadas: século XIX: 1831 a 1850 (g);

1851 a $1900(\mathrm{~h})$;

século XX: 1901 a 1950 (z);

1951 a $2000(w)$.

8. Gênero das peças: comédia (c);

drama (d).

9. Classe social das personagens: popular (q);

não popular (u).

10. Gênero das personagens: masculino (y);

feminino $(\mathrm{x})$.

A justificativa pela escolha dos fatores linguísticos acima mencionados se dá por alguns estudos como o de Berlinck (1997), no qual a autora constatou que o aumento no uso do OI nulo começa entre os casos de referência de terceira pessoa gramatical e entre aqueles que constituem complementos de verbos de transferência verbal e perceptual. 
Ainda nesse estudo, a autora sugere que, no caso do OI, o processo de mudança atinge os casos em que o complemento tem um papel temático meta. Os resultados de outro estudo Berlinck (1996b), confirmam o traço [+ animado] como o mais característico do OI.

Alguns trabalhos sobre o PB, como o de Morais (2002) mostram a tendência da variedade brasileira em substituir a preposição $a$ pela preposição para com os verbos bitransitivos de transferência ou movimento. Além disso, o clítico lhe tem sido substituído pelo oblíquo a ele/a ela, outra reanálise que não se verifica no PE.

Mais especificamente, segundo a autora, no caso do dativo lhe, a forma em competição é o sintagma preposicional a/para ele(a) na terceira pessoa e a/para você na segunda pessoa.

Apoiando-nos nos estudos da Sociolinguística Variacionista, consideramos, do mesmo modo, alguns fatores extralinguísticos, como as décadas em que cada peça foi escrita, bem como seu gênero, uma comédia ou um drama, explicitados, mais adiante, no capítulo 4. Em relação às personagens, consideramos a classe social a qual pertencem e seu gênero.

Buscando uma classificação da classe social das personagens, nos baseamos no estudo de Martins (2011) que repensa o tema da colocação dos pronomes clíticos na história do português, observando nove peças e 48 personagens populares de Gil Vicente.

Assim, em seu estudo, lavradores, alcoviteiras e judeus fundem-se numa grande família geral: a das personagens populares. A esta família pertence também uma multidão de figuras menos diferenciadas: criados, artesãos, comerciantes, frades, porteiros, pagens. Assim, classificamos, neste presente estudo, personagens populares e personagens não populares.

Vários estudos, como de Freire (2000), analisam o sexo do informante, a fim de detectar a possível influência do fator sexo na ocorrência de cada variante. Neste estudo, chamamos esse fator gênero das personagens.

Se levarmos em conta a natureza potencialmente plurilíngue do texto dramático, podemos identificar relações entre usos linguísticos e papéis sociais. Se esse tipo de texto é construído para representar várias vozes, a linguagem deveria ser empregada pelo autor de modo a definir os diversos personagens. Assim, existe uma possibilidade de se estabelecer uma relação pertinente entre as características não linguísticas de cada 
personagem - idade, sexo, ocupação, grau de escolaridade - e a expressão variável de aspectos fonético-fonológicos, morfológicos, sintáticos e lexicais. 


\section{CAPÍTULO 3}

O corpus sob análise

O presente trabalho de pesquisa se propõe a investigar, numa perspectiva diacrônica, a ocorrência das diferentes estratégias que realizam o OI no PB. Para tanto, foram selecionadas, para compor o corpus, peças de teatro de autores variados e consagrados do teatro brasileiro, sendo sete peças do século XIX e dez do século XX, totalizando dezessete peças, abaixo especificadas, por data e autor.

- O Juiz de Paz da Roça (1833) - Martins Pena;

- O Noviço (1845) - Martins Pena;

- O Demônio Familiar (1857) - José de Alencar;

- Sangue Limpo (1861) - Paulo Eiró;

- Amor com Amor se Paga (1870) - França Júnior;

- Como se Fazia um Deputado (1882) - França Júnior;

- A Capital Federal (1897) - Artur Azevedo;

- Lição de Botânica (1905) - Machado de Assis;

- Flores de Sombra (1916) - Cláudio de Souza;

- Onde Canta o Sabiá (1921) - Gastão Tojeiro;

- O Rei da Vela (1933) - Oswald de Andrade;

- Vestido de Noiva (1943) - Nelson Rodrigues;

- A Moratória (1954) - Jorge Andrade;

- Navalha na Carne (1966) - Plínio Marcos;

- Um Grito Parado no Ar (1973) - Gianfrancesco Guarnieri;

- A Aurora da Minha Vida (1981) - Naum Alves de Souza;

- Intensa Magia (1995) - Maria Adelaide Amaral.

Estas peças foram escolhidas por serem consideradas, na época em que foram encenadas, de grande êxito. Esse critério do sucesso de uma peça, pareceu-nos indicativo 
de que elas não somente tratavam de aspectos políticos e sociais relevantes, como utilizavam uma linguagem mais próxima do coloquial, portanto mais acessível ao grande público. Além disso apresentavam personagens que refletiam a cultura nacional.

Por serem peças de teatro escritas por diferentes autores, com estilos particulares, ao longo de um percurso temporal, acreditamos que nos fornecerão boas evidências para os objetivos de nosso estudo.

Berlinck (2008) observa que, na medida em que processos de variação se iniciam na língua falada, nas interações cotidianas e coloquiais dos falantes de uma mesma comunidade, a observação de uma fonte que representa esse tipo de interação, como as peças de teatro, em períodos para os quais não se dispõe de dados concretos de fala, parece constituir um recurso inestimável.

De fato, como sabemos, estudos recentes sobre a história do PB, como os de Berlinck (1999), Cyrino (1993) e Duarte (1993), apoiaram-se em peças de teatro.

Neste capítulo vamos nos dedicar a relatar, em maiores detalhes, informações sobre as peças selecionadas e seus respectivos autores, juntamente com um brevíssimo panorama do teatro brasileiro dos séculos em questão.

As peças de teatro estão dispostas em ordem cronológica.

\subsection{Peças de teatro do século XIX}

Sábato Magaldi (1999:27) aponta um vazio teatral entre os séculos XVII e XVIII, por vários motivos. Primeiro, havia falta de documentação. Segundo, eram novas as condições sociais do país, entre elas, a ausência do teatro catequético dos jesuítas. Por fim, com os problemas decorrentes da invasão dos franceses e holandeses, comprometese o panorama cultural e artístico necessário para a produção teatral.

Na segunda metade do século XVIII, segundo Magaldi, teria havido um pequeno progresso da atividade cênica, que alguns anos mais tarde, atingiriam uma fase produtiva, decorrente das novas condições sociais do país.

Segundo o autor, ainda no início do século XIX não se alteram muito as características descritas para o século XVIII. Assim, é necessário que se configure a 
independência política, ocorrida em 1822, para que o país assuma uma identidade nacional e, com isso o teatro brasileiro ganhe um novo impulso.

Explica-se dessa forma que as peças escolhidas, para compor o nosso corpus, sejam datadas a partir da década de 30 do século XIX.

A seguir, traremos algumas informações mais detalhadas a respeito de cada peça. Lembramos que, a data da estreia de uma peça nem sempre coincide coma data de sua publicação.

\subsubsection{Martins Pena}

A 4 de outubro de 1838 estreava O Juiz de Paz da Roça, no teatro São Pedro, pela companhia de João Caetano. Era a primeira comédia escrita por Martins Pena (18151848), de feitio popular e, expondo com observação satírica, um aspecto da realidade brasileira.

Segundo Sábato Magaldi (1999:42), começava aí uma carreira curta e fecunda (Martins Pena escreveu dos 22 aos 33 anos de idade, quando morreu, 20 comédias e 6 dramas), e o verdadeiro teatro nacional, naquilo que ele tem de mais específico e autêntico. Martins Pena é considerado o fundador da nossa comédia de costumes e responsável pela maioria das obras que realmente contam na literatura teatral brasileira.

O Juiz de Paz da Roça representa uma farsa centralizada na curiosa personagem de um juiz conciliador e corrupto que toma ao pé da letra sua função, impondo justamente a "conciliação" a todos os casos que são apresentados em seu tribunal interiorano, abusando da boa fé das pessoas simples da roça. Paralelamente, temos nessa comédia o namoro de dois jovens, José e Aninha, que se veem atingidos pelo recrutamento de soldados para a Guerra do Paraguai.

Como o recrutamento não servia para os casados, a única solução para quem não quisesse ir ao Paraguai era o matrimônio.

Portanto, o recrutamento tornou-se verdadeiro Santo Antônio para José que, encontrado na rua sem lenço e sem documento, foi preso e entregue a quem haveria de ser o seu futuro sogro. O engraçado da peça é que o próprio carcereiro, Manoel João, desconhecia o romance entre o jovem preso e sua filha, Aninha. 
O fato de ter sido aprisionado em um quarto, na própria casa do carcereiro, constitui uma excelente ocasião para o casal, que não sabia como realizar seu desejo de casamento. Quando surge uma oportunidade, a noiva consegue libertar o aprisionado, o que possibilita que ambos consigam fugir para a igreja, onde se concretiza o sonhado casamento. Com isso, José escapa do recrutamento. Após descobrirem o fato consumado, os pais perdoam a jovem e vão ao Juiz de Paz esclarecer o caso e a peça se encerra com todos comemorando. Portanto, dentro do enredo encontramos paralelamente aos atos do Juiz de Paz as vicissitudes de um núcleo familiar, constituído pela família de Aninha.

Martins Pena também é autor de $O$ Noviço, outra comédia, em que Ambrósio, que é bígamo, pretende ficar rico, roubando a herança dos filhos de sua esposa Florência.

Sua filha, Emília, encontra-se em idade de se casar, e se isso ocorrer, Florência terá de dar ao noivo um dote, algo que desagrada Ambrósio. Então, este convence-a de que a filha deveria ir para o convento. Do mesmo modo, persuade a esposa a também mandar para o convento seu filho, Juca, para se tornar frade.

Com isso, Ambrósio garantiria a sua tão cobiçada herança. Mas eis que surge Carlos (o noviço), interno do convento a contragosto, sobrinho de Florência, que quer acabar com o projeto do tio, pois o sonho do Noviço é casar-se com sua prima Emília, que também é apaixonada por ele.

Carlos descobre, porém, que o padrasto da amada convenceu sua tia a colocar os filhos em um convento. Assim sendo, não seria possível a realização do matrimônio.

Então, Carlos usa a outra mulher, Rosa, com quem Ambrósio também é casado. Ela aparece na casa de Florência e pensando ser Carlos um padre, conta a ela estar à procura do marido que desaparecera com todo o dinheiro que possuía e que gostaria de confirmar a informação de que Ambrósio se casara novamente.

Com esse trunfo nas mãos, o Noviço começa a chantagear Ambrosio. O bígamo, com medo de ser desmascarado, cede. Após confusões, finalmente, Ambrósio é preso, o Noviço é liberto do convento e assim o seu casamento com Emília pode ser realizado.

A respeito da linguagem de Martins Pena encontramos registrado que o autor possuía um vocabulário preciso e variado. Segundo Magaldi (1999:57), na literatura dramática portuguesa, apenas Gil Vicente teria conseguido semelhante adequação das 
falas à psicologia e ao estado social das personagens. Martins Pena aproveitava no diálogo de suas peças as expressões mais brasileiras do tempo, repelindo todo o sabor classicista de linguagem, adotando maneiras da fala comum do povo.

Vale destacar que suas peças, como pudemos constatar nas duas comédias que selecionamos, satirizam os costumes na época do rei, com personagens populares, como que tiradas das ruas do Rio de Janeiro e colocadas no papel: malandros, moças com ânsia de casar, juízes, estrangeiros, jovens pomposos, velhas solteiras, funcionários públicos, meirinhos, contrabandistas, etc.

O âmbito social e o enredo escolhidos por Martins Pena também refletia os eventos sociais da época, entre eles, casamentos, festas na roça, festas da cidade, decisão de herança, pagamento de dotes, e assim por diante.

Martins Pena, com certeza, ofereceu uma identidade ao teatro brasileiro, dando ao mesmo cunho histórico, uma vez que retratava a própria sociedade brasileira da primeira metade do século XIX.

\subsubsection{José de Alencar}

Outra peça considerada como uma das melhores comédias brasileiras de todos os tempos é O Demônio Familiar, de José de Alencar (1829-1877), que estreou em novembro de 1857.

Alencar centra seu enredo nas traquinagens do escravo doméstico Pedro, que teima em intrometer-se nos assuntos de seu senhor, o médico Eduardo, protagonista na trama. Pedro tinha o propósito de conseguir um matrimônio rico com uma vizinha viúva para o senhor Eduardo. O que o animava era a ideia de desfazer um noivado pobre, com Henriqueta para, através da melhoria financeira, alcançar a ambicionada posição de cocheiro. Sua obstinação em pertencer a um proprietário rico leva-o a garantir um "bom casamento" agora para sua senhora, Carlotinha, irmã de Eduardo. Ele arranjou para que sua senhora casasse com Azevedo, mas a jovem nutria um amor por Alfredo.

Após muitas peripécias, o próprio Eduardo é quem desmancha a série de "nós" trançados por Pedro, e esclarece todos os equívocos, colocando todo o enredo de volta 
aos eixos e reestabelecendo os pares iniciais - Eduardo casar-se com Henriqueta e Alfredo com Carlotinha.

Registra-se em Magaldi (1999:98-99) que José de Alencar fez algumas considerações sobre a peça, revelando que, "no momento em que resolvi a escrever $O$ Demônio Familiar, sendo minha tenção fazer uma alta comédia, lancei naturalmente os olhos para a literatura dramática do nosso país, em procura de um modelo (...)Não achando pois na nossa literatura um modelo, fui buscá-lo no país mais adiantado em civilização, e cujo espírito tanto se harmoniza com a sociedade brasileira: na França".

Essa influência se faz presente através da personagem Azevedo, que mescla sua fala com expressões em francês: "Falta-lhe o savoir-vivre!".

\subsubsection{Paulo Eiró}

Em janeiro de 1861 Paulo Eiró (1836-1871) publicou o drama Sangue Limpo, que estreou em 2 de dezembro do mesmo ano na Casa da Ópera. O autor compôs esse drama para ser apresentado em concurso aberto pelo Conservatório Dramático Paulistano. A peça atendia aos objetivos do concurso que era pôr em prática uma ideia cheia de patriotismo, destinando prêmios para o melhor drama original, revestido de moralidade, que tivesse por assunto algum dos gloriosos episódios da história de nosso país.

No enredo da peça, pode-se notar uma mescla de amor, orgulho e preconceito racial na intriga que envolve Luísa e Aires, filho do aristocrata Dom José de Saldanha. Este não se conforma em aceitar a união de seu único filho com a irmã de um reles sargento de milícias (Rafael). E pior, os dois são filhos de uma mulata que engravidara de seu dono.

O desenlace revela uma certa ingenuidade temperada com otimismo, tragicidade e patriotismo: morre Dom José de Saldanha, Luísa e Aires casam-se, enquanto às margens do Ipiranga se ouve o brado heróico e retumbante - Independência ou Morte! 


\subsubsection{França Júnior}

De acordo com Magaldi (1999:140), o verdadeiro continuador de Martins Pena, na preocupação de fixar os costumes da época, foi França Júnior (1838-1890).

Segundo o autor, diversas características análogas aproximam a obra de ambos. Martins Pena é mais ingênuo e espontâneo, formado no clima romântico; França Júnior é mais realista e elaborado, e se deixa às vezes contaminar pela vulgaridade que se propagou nos espetáculos da segunda metade do século XIX.

Em nossa pesquisa, pudemos saber que sua peça Como se fazia um Deputado teve um êxito retumbante, constituindo um absoluto sucesso de público, com ruidosa ovação na estreia, jornalistas presentes subindo ao palco, alguns deles saudando o autor.

A ação da peça transcorre no interior da província do Rio de Janeiro, fixando o processo de ascensão de Henrique, um recém-formado bacharel em Direito ao posto de deputado. Passa-se em cena o episódio da votação, com a interminável chamada de defuntos e a troca de eleitores.

O apoio ao jovem bacharel é tratado pelo pai, Limoeiro, rico fazendeiro, que inclui no negócio o casamento com a filha de outro chefe político, Chico Bento.

Este tem a esposa Dona Perpétua, a filha Rosinha e um palavreado político entremeado de citações em latim acaboclado. Limoeiro representa o poder econômico e o tenente-coronel Chico Bento, a influência. Assim, o governo fica sempre em família, tendo Rosinha como elemento unificador mediante o casamento com Henrique.

Também de autoria de França Junior, Amor com Amor se Paga, fixa um episódio original.

A personagem Miguel Carneiro, fugindo de uma situação embaraçosa, esconde-se justamente na sala de visitas onde Vicente está esperando, para o jantar, uma visita galante. Miguel, obviamente escondido debaixo da mesa, descobre que a mulher esperada por Vicente é sua própria esposa.

Por sua vez, a mulher que Miguel ama precipita-se na sala à procura dele, para descobrir que Vicente, seu marido, é o outro homem presente. Dois indivíduos, sem o saber, cortejavam um a mulher do outro. 
A situação é altamente embaraçosa, porém se resolve de modo divertido, pois as duas mulheres, embebidas de literatura e de romances franceses na moda, amaram os dois homens platonicamente, permanecendo, na verdade, fiéis a seus maridos.

\subsubsection{Artur Azevedo}

Magaldi (1999:153) considera que Artur Azevedo tenha fechado um ciclo do nosso teatro, nascido com as comédias de Martins Pena, de quem foi herdeiro direto. Sua comédia A Capital Federal, que está entre as obras-primas da nossa dramaturgia, é considerada um resumo feliz das características de uma época.

A trama pode ser resumida nos seguintes termos: a fim de mostrar "a capital federal", Artur Azevedo levou a ela uma família de interioranos de São João do Sabará, cujos costumes contrastam com o aparato da Corte.

Os mineiros, de hábitos rígidos e vida simples, o pai (Eusébio), a mãe (D. Fortunata) e o filho menor (Juquinha) exprimem-se em linguagem caipira, viajam para o Rio à procura de um janota (Gouveia), que pedira a filha moça (Quinota) em casamento e nunca mais dera notícia.

O contato da família com os valores cariocas (isto é, a ausência de valores morais) dispersa seus membros, e só resistem à ação desagregadora mãe e filha, representantes da austeridade e da boa índole mineira.

A primeira a corromper-se ao contato da metrópole é a mulata Benvinda, cria da família e que é "lançada" no brilho carioca pelo desocupado Figueiredo.

Eusébio, o fazendeiro simples, cai nas garras da cortesã Lola, cujo único empenho é arrancar dinheiro dos homens.

O menino Juquinha aplica-se no Belodromo, atraído pelas bicicletas, que acabavam de ser introduzidas no Rio e não haviam chegado à roça.

Passada a embriaguez da capital, todos voltam para Sabará.

A mulata casa-se com o feitor Borges e Gouveia casa-se com Quinota.

Nota-se, na peça, o contraste entre o caipirismo dos mineiros, que falam com sotaque característico, e o ambiente do Rio de Janeiro. 
Notamos que, dentre todas as peças analisadas, esta é a única que apresenta o clítico the empregado de outra forma: le. Sempre na fala das personagens caipiras, como por exemplo da criada Benvinda "Quem le disse?" e Eusébio "Vá chamá êle. Quero Le dá uma lambuge!"

Este era, de um modo geral, o panorama do teatro brasileiro no século XIX. A comédia de Martins Pena representa de fato o marco inicial da fixação dos costumes brasileiros, que são explorados por José de Alencar, França Júnior e Artur Azevedo, os principais cultores do gênero, numa continuidade de trabalhos que vem até o princípio do século XX.

3.2 Peças de teatro do século XX

Nas três primeiras décadas do século XX nosso teatro continua com as mesmas características do século XIX.

\subsubsection{Machado de Assis}

Machado de Assis (1839-1908), considerado um dos maiores escritores da literatura universal, interessou-se por todos os gêneros literários. Como muitos contemporâneos, Machado dedicou ao teatro uma parte de sua produção, a qual deve ser lembrada, sobretudo, em função da grandeza do romancista.

Cacciaglia (1986) considera que a peça mais delicada do teatro machadiano é a última comédia, Lição de Botânica, que está, sem dúvida, à altura de sua narrativa, pela delicadeza dos diálogos e das situações.

No centro da ação está Helena, a quem a irmã, Cecília, recorre para conseguir ajuda em suas aspirações sentimentais: quer casar-se com o sobrinho (Henrique) de um barão sueco. Este, porém, está absolutamente decidido a que o jovem se dedique ao estudo da botânica, achando inconciliáveis o matrimônio e esta ciência.

Helena, mostrando-se também apaixonada pela botânica, consegue seduzir o tio rabugento, que não só se oferece para dar-lhe aulas dessa ciência como acaba pedindo-a em casamento. 
Helena convence-o e Cecília e Henrique casam-se.

\subsubsection{Cláudio de Souza}

Com a Guerra de 1914-1918, o Brasil afasta-se da Europa.

De acordo com Magaldi (1999:191), o país, que sempre recebera a visita dos maiores nomes do teatro francês, italiano e português, viu-se de súbito isolado dos centros culturais, necessitando abrir um caminho por conta própria.

Magaldi acredita que o grande êxito da peça Flores de Sombra, de Cláudio de Souza (1876-1954), apresentada inicialmente em São Paulo, em 1916, e a seguir no Rio de Janeiro, se explica em grande parte pelo reencontro da valorização das virtudes campestres, dos troncos tradicionais da família brasileira, em contraste com a degeneração dos hábitos citadinos.

Flores de Sombra sustenta-se em três atos bem estruturados.

D.Cristina prepara-se para receber o filho Henrique, na fazenda paulista de móveis antigos e retratos de antepassados. Mas Henrique, dissociado no tumulto da metrópole e namorando Cecília, filha de um ministro, aceita modernizar o ambiente para receber os hóspedes Cecília, Mme. Cardoso, sua mãe, e Oswaldo, o companheiro de infância, que dissipara suas posses na vida da cidade.

O confronto da vida pacata da fazenda com as maneiras levianas dos visitantes enaltece os valores antigos, ainda mais que Cecília, empurrada para o bom partido que representa Henrique, pouca afinidade tem com ele.

Henrique acaba afastando-se de Cecília e reencontra o amor de Rosinha, a namorada de infância, que esperou longos anos a volta de Henrique.

\subsubsection{Gastão Tojeiro}

A dramaturgia se volta para os temas brasileiros, mesclando a comédia de costumes com a reivindicação dos valores nacionais. 
A peça, Onde Canta o Sabiá, de Gastão Tojeiro (1880-1962), cuja estreia se deu no Rio de Janeiro, em 1921, exemplifica bem a tendência que haveria de dominar duas décadas, retomando com as sugestões da época, o fio iniciado em Martins Pena.

Para Magaldi (1999:192), como se trata de fixar os nossos vícios, Onde Canta o Sabiá ironiza o sistema de visita a uma autoridade, com o objetivo de conseguir emprego no serviço público, e o prazer da vadiagem e a moleza no trabalho, expressa pelo chefe da estação.

Naquela vida do subúrbio carioca, aparece Elvídio, que vive em Paris e só veio ao Rio para vender umas propriedades.

Seduzido, porém, pela jovem Nair, Elvídio abdica dos prazeres parisienses. O contraste, que antes se fizera entre o campo e a cidade, se transfere agora do país para o estrangeiro. O sabiá, que fugira, foi apanhado e reina outra vez naquela sala de visitas.

\subsubsection{Oswald de Andrade}

Os problemas com o café em 1929 e o golpe de estado em 1930 modificam o panorama político nacional. A crise capitalista com o crack da Bolsa de Nova York (derrota do capitalismo) versus o progresso avassalador das reformas na antiga Rússia (vitória do comunismo) levam, por um lado, os homens de esquerda a terem certeza de que as ideias marxistas brevemente conquistarão o mundo; e, por outro lado, mobilizam a burguesia a lutar de todas as formas para não perder o poder ameaçado.

A esquerda teve a certeza da "revolução" na década de 1930. A burguesia foi mais hábil nesses dois momentos, soube fazer alianças com a aristocracia rural, com a igreja católica e com os militares. E eternizou-se no poder.

Esse vai ser o tema de O Rei da Vela, de Oswald de Andrade (1890-1954) que é um dos grandes nomes da Semana de Arte Moderna em 1922. O Rei da Vela é ligado aos dados concretos de um teatro realista.

A peça é ambientada em São Paulo, no escritório de usura de Abelardo \& Abelardo. A sátira está dirigida aos intelectuais vendidos, à decadente aristocracia aliada da burguesia corrupta, à invasão do capital estrangeiro, enfim, Oswald analisa, com extrema visão crítica, a situação política nacional. 


\subsubsection{Nelson Rodrigues}

Vestido de Noiva, de Nelson Rodrigues (1912-1980), foi uma verdadeira apoteose, estreada em 28 de dezembro de 1943, dirigida por Ziembinski e montada no Teatro Municipal do Rio de Janeiro.

A peça traduz a entrada definitiva do nosso país no universo da arte do teatro: o Brasil, enfim, revela-se como um país criador de uma cena teatral de alta qualidade, pela feliz união de múltiplos fatores, ausentes antes em nossas peças.

A protagonista de Vestido de Noiva é Alaíde, deprimida e aniquilada por uma briga com a irmã por causa de problemas conjugais.

Ao sair de casa é atropelada por um automóvel.

A ação desenrola-se nas últimas horas de vida da mulher, em três planos: o da realidade (os médicos tentam operá-la, mas no fim a paciente falece), o da memória (o passado da protagonista) e o do inconsciente (os sonhos e as alucinações).

Assim, durante os três atos desenvolvem-se paralelamente duas histórias, as de Alaíde, de seu marido e da irmã, e a história de amor de Madame Clessi por um belíssimo adolescente, cujo caso a protagonista lera num jornal.

$\mathrm{Na}$ memória e na alucinação os dois fatos se fundem e o jovem amado por Madame Clessi aparece com os traços do marido de Alaíde.

No final temos a superposição da marcha fúnebre com a marcha nupcial, anunciando o matrimônio entre o viúvo da protagonista com sua irmã.

\subsubsection{Jorge de Andrade}

Transcorre mais de uma década para que apareça nova obra, sólida e original, e ao mesmo tempo filtre o que de melhor trouxera Vestido de Noiva: era A Moratória, do dramaturgo paulista Jorge Andrade (1922-1984). Significativamente, a peça foi apresentada em 1955, no Teatro Maria Della Costa, em seguida ao surto imobiliário que multiplicou as casas de espetáculos em São Paulo.

A Moratória é ambientada nos anos da crise do café (por volta de 1929). 
Jorge Andrade retrata o drama dos latifundiários que em pouco tempo passaram de senhores da terra a quase proletários da periferia paulista, sem a riqueza e sem aquela liberdade externa que só os grandes espaços podem dar.

A crise social atinge o fazendeiro Joaquim, assistimos à queda da aristocracia rural. A ação se arrasta, com alternativas de esperanças e decepções cruéis, até 1932, o ano da revolução constitucionalista de São Paulo.

\subsubsection{Os autores contemporâneos}

Um dos dramaturgos mais importantes dos anos 60 é Plínio Marcos (1935-1999). $\mathrm{O}$ autor construiu peças de grande intensidade dramática e impacto, conduzindo para o teatro, com realismo brutal, as tragédias das classes marginalizadas dos centros urbanos do Brasil.

As personagens são capazes dos atos mais ignóbeis, em um cenário que não oferece qualquer vislumbre de grandeza ou de remissão, a linguagem é construída sem qualquer requinte e os diálogos se desenvolvem com muita aspereza e violência.

Assim se constrói a peça Navalha na Carne, o maior sucesso de bilheteria do autor, que tem, como protagonistas, três personagens: uma prostituta, um homossexual e um gigolô, exprimindo-se em uma linguagem de inteira crueza, que não recua ante o palavrão.

Entre o homossexual e a mulher estabelece-se um esboço de relação humana, apesar da desolação de seu ambiente e de sua condição, uma vida subumana e marginal.

O homossexual, que cometera um pequeno furto, aproveitando-se do fato de ser faxineiro, é morto pelo gigolô. A peça recebeu uma adaptação para o cinema em 1967.

Gianfrancesco Guarnieri (1934-2006) escreveu a peça Um Grito Parado no Ar, um dos primeiros espetáculos que conseguiu furar o cerco da Censura em plena ditadura, por meio de uma linguagem metafórica, que revela o inconformismo e a rebeldia característicos do período.

A peça gira em torno de um grupo de teatro em seu processo de trabalho e ressalta as dificuldades que enfrentam dentro e fora dos palcos. 
Outro dramaturgo de destaque é Naum Alves de Souza (1942). A peça A Aurora da Minha Vida conquista os prêmios APCA (Associação Paulista de Críticos de Arte) e Molière como o melhor texto de 1981.

No texto, o autor desenvolve uma história de profunda reflexão e lirismo, que não suprime uma censura, embora velada, ao sistema educacional no que há de obsoleto. São antigos hábitos, cacoetes, modos de pensar e comportamentos que vêm dos tempos passados.

O cenário único da peça é uma sala de aula, habitada por criaturas que Naum, mesmo quando ironiza, compreende sempre: o menino bajulador, as gêmeas, criadas para serem iguais em sua mediocridade, a menina rica e primeira da classe, o menino que sonha com a carreira militar.

E professores de todos os tipos, principalmente repressores.

Mas o texto de Naum não só captura implacavelmente a mesquinhez humana como também é capaz de iluminar para o espectador esse tecido de pequenas maldades, covardias e dissimulações que constituem o cotidiano.

Entre as já numerosas peças que escreveu, Intensa Magia, de grande sucesso, é aquela em que Maria Adelaide Amaral (1942) foi mais fundo no tema das relações familiares ou, melhor, tratou sem nenhum véu embelezador o convívio adulto de um pai torturado com a mulher e os filhos.

Concluindo esta breve apresentação das peças que compõem o corpus de nosso estudo das diferentes variantes do OI na história do PB, esperamos ter deixado claro nossa intenção de escolher peças que pudessem refletir riqueza dialógica, variedade de personagens, situações e épocas.

Por trás desta escolha estão os pressupostos de que uma teoria internalista, a teoria do Princípios e Parâmetros, e a teoria Variação e Mudança se completam na busca do entendimento dos intrincados fatores que se manifestam na dinâmica da mudança sintática. 


\section{CAPÍTULO 4}

\section{Análise dos dados}

Neste capítulo, serão apresentados os resultados obtidos na análise dos dados. Para a descrição e análise das ocorrências do OI no PB, observadas nas peças de teatro dos séculos XIX e XX, foram considerados alguns fatores linguísticos e extralinguísticos, apresentados no capítulo 2, que, em tese, condicionariam a escolha de uma ou outra variante do fenômeno estudado, a variável dependente OI.

Conforme exposto anteriormente, consideraremos três possibilidades de realização do complemento OI com interpretação anafórica, a seguir:

- clítico dativo lhe/te;

- preposição + pronome forte (a/para elelela; a/para você);

- nulo.

Os exemplos, abaixo, ilustram as três variantes e estão disponibilizados por décadas:

a - Clítico dativo lhe/te $e^{39}$ :

(1)"Mas se era meu, e o senhor nem mo comprou, nem $\boldsymbol{l h o}^{40}$ dei, como pode ser seu?" (O Juiz de Paz da Roça 1833).

(2)“Sim, maquinismo. Eu te explico. Uma árvore se vira em uma barraca; paus viram-se em cobras, e um homem vira-se em macaco" (O Juiz de Paz da Roça 1833).

(3) "Irei hoje mesmo ao convento falar ao D. Abade, e dir-lhe-ei que temos mudado de resolução a teu respeito" (O Noviço 1845).

(4)“Como queres que eu to diga, Florencinha?” (O Noviço 1845).

\footnotetext{
${ }^{39}$ Aqui consideramos o clítico the de $2^{\mathrm{a}}$ e $3^{\mathrm{a}}$ pessoas.

${ }^{40}$ Formas do tipo lha/lhas e lho/lhos são constantemente usadas pelos autores do século XIX. Diferentemente do século XX, onde estas formas não são vistas com frequência ou, simplesmente, inexistem, principalmente nas peças de teatro da segunda metade do século XX.
} 
(5)“Já lhe disse tudo, já lhe dei a carta; prometo-lhe não pensar mais nele" (O Demônio Familiar 1857).

(6)“"E que tenho eu para dar-lhe em troca de isso tudo? Meu amor só. Pois bem!... eu lho dou e quero que me agradeça" (Sangue Limpo 1861).

(7) "Miguel, eu te juro pela minha vida que estou inocente" (Amor com Amor se Paga 1870).

(8)“Vá chamáêle. Quero le dá uma lambuge!” (A Capital Federal 1897).

(9)“Quem lho disse?” (Lição de Botânica 1906).

(10) "Estou prompto a dar-lh'o, com a condição, porém, que ella mesma venha buscal-o. Diga-lhe que sou um mau retratista, mas só entrego o retrato ao dono" (Flores de Sombra 1916).

(11) "É verdade que eu tenho por esse passarito uma amizade de pai solteiro, mas eu tinha satisfação em lho dar. A menina é tão boa...” (Onde Canta o Sabiá 1921).

(12) "Com que direito o senhor me propõe uma redução no capital que eu the emprestei?" (O Rei da Vela 1933).

(13)“Alaíde! Olhe o que eu lhe disse!” (Vestido de Noiva 1943).

(14) “Olha aqui, Vado, já vou te avisando" (Navalha na Carne 1966).

(15) “Roma, eu já lhe contei a história de Sissi, a imperatriz?" (Intensa Magia 1995).

$\mathrm{b}$ - Preposição + pronome forte (a/para ele/ela; a/para você) $:$

(16) "Pois olhe, nhanhã tira duas violetas; põe uma nos cabelos, manda outra $a$ ele!" (O Demônio Familiar 1857).

(17) "Vai, vai dizê a ele que não tô zangada!" (A Capital Federal 1897).

(18) "Eu vou dizer $\boldsymbol{a}$ você se estão ou não" (Onde Canta o Sabiá 1921).

(19) "Não ponho minha filhinha na escola porque não posso comprar sapatos para ela" (O Rei da Vela 1933).

(20) "Darei a você tudo que desejar" (A Moratória 1954).

(21) "Eu já mostrei pra você o cartão que ela me mandou uma vez de Viena?" (Intensa Magia 1995). 
c - Nulo

(22) “Senhor presidente, pedi [Ø] a palavra para dizer [Ø]..." (Como se Fazia um Deputado 1881).

(23) “Senhor, eu pagarei [Ø] êsse dinheiro logo que puder...” (A Capital Federal 1897).

(24) "Ensinar botânica à Helena? Já me deu vinte e quatro horas para responder [Ø]” (Lição de Botânica 1906).

(25)"Vim trazer [Ø] a sua begonia, mãesinha" (Flores de Sombra 1916).

(26) “Não sei explicar [Ø] o que seja, mamãe” (Onde Canta o Sabiá 1921).

(27) "Mas você... Ah, meu Deus. Aposto que não acredita em nada do que eu [Ø]contei” (Vestido de Noiva 1943).

(28) "Você me perdoa, Neusa Sueli? Eu devolvo [Ø] tudinho. Eu não aguentei" (Navalha na Carne 1966).

(29) “Olha, se for até o fim do mês eu posso emprestar [Ø] trezentos..." (Um Grito Parado no Ar 1973).

(30) “Escutem uma história que a mamãe vai contar [Ø] que aconteceu com um menino na escola" (A Aurora da Minha Vida 1981).

\subsection{Resultados da análise quantitativa}

Para a obtenção dos resultados da análise dos dados, seguem-se os moldes da Sociolinguística Quantitativa, cujos pressupostos dão conta de explicar que a variação linguística não é aleatória, sendo, portanto, fundamental identificar os fatores linguísticos e sociais que favorecem ou desfavorecem o uso de uma ou outra variante. Para essa análise nos apoiamos nos programas computacionais Goldvarb. Embora seja possível obter os pesos relativos através desse programa, neste estudo, como optamos por três variantes, somente foi possível obter as frequências dos dados.

Vamos aos resultados: 


\subsubsection{As variantes}

Os resultados percentuais relativos a cada uma das variantes estão expostos na Tabela 8. Tais resultados foram obtidos nas peças de teatro ao longo dos séculos XIX e XX, num total de 1268 dados:

\begin{tabular}{|c|c|c|c|}
\hline & Clítico & Pronome Forte & Nulo \\
\hline $\mathrm{N}^{\mathrm{o}} /$ Total & $594 / 1268$ & $61 / 1268$ & $613 / 1268$ \\
\hline$\%$ & $47 \%$ & $4 \%$ & $49 \%$ \\
\hline
\end{tabular}

Tabela 8. Distribuição dos dados segundo as variantes do OI

Pela tabela, podemos depreender que, embora o percentual das ocorrências com as formas nulas seja superior, atingindo $49 \%$ do total dos dados, o percentual dos clíticos é quase equivalente, com $47 \%$. Já o pronome forte, introduzido por preposição, conta com um número ainda não muito significativo, $4 \%$.

Lembramos que, quando nos referimos à variante clítico, estamos considerando, nesta Tabela 8 , tanto o clítico lhe/lhes de $2^{\mathrm{a}}$ e $3^{\mathrm{a}}$ pessoas como o clítico te.

Nas tabelas que se seguem, apresentamos o resultado geral das ocorrências das três variantes separadamente. Primeiramente, as ocorrências com a $3^{\mathrm{a}}$ pessoa, em seguida com a $2^{\mathrm{a}}$ pessoa.

\begin{tabular}{|c|c|c|c|}
\hline & Clítico & Pronome Forte & Nulo \\
\hline $\mathrm{N}^{\mathrm{o}} /$ Total & $172 / 395$ & $32 / 395$ & $191 / 395$ \\
\hline$\%$ & $43 \%$ & $9 \%$ & $48 \%$ \\
\hline
\end{tabular}

Tabela 9. Distribuição dos dados segundo as variantes do OI de $3^{\mathrm{a}}$ pessoa

A Tabela 9 mostra que, no total de 395 ocorrências com a $3^{\text {a }}$ pessoa, 191 ocorrem com a forma nula (48\%). Por sua vez, o clítico atinge o total de 172 ocorrências (43\%), 
ao contrário do pronome forte ainda não conta com um número significativo, com 32 ocorrências $(9 \%)$.

Vamos às ocorrências com a $2^{\mathrm{a}}$ pessoa:

\begin{tabular}{|c|c|c|c|}
\hline & Clítico & Pronome Forte & Nulo \\
\hline $\mathrm{N}^{\mathrm{O}} /$ Total & $422 / 873$ & $29 / 873$ & $422 / 873$ \\
\hline$\%$ & $48 \%$ & $4 \%$ & $48 \%$ \\
\hline
\end{tabular}

Tabela 10. Distribuição dos dados segundo as variantes do OI de $2^{\mathrm{a}}$ pessoa

Já na Tabela 10, no total de 873 ocorrências, o clítico e o nulo apresentam o mesmo número, 422 (48\%). O pronome forte, aqui também, ainda não conta com um número significativo, 29 ocorrências (4\%). Lembrando que, mais uma vez, estamos computando juntos os clíticos lhe e te de $2^{\mathrm{a}}$ pessoa.

$\mathrm{Na}$ análise que se segue, expõem-se os fatores linguísticos que tem sido os mais destacados nos vários estudos sobre o OI, como exposto no capítulo 1.

\subsubsection{Fatores linguísticos}

\subsubsection{Contextos verbais}

Como mencionado no capítulo 1 deste trabalho, consideramos cinco diferentes tipos verbos para a expressão dos OIs, quatro deles identificados semanticamente na tipologia formulada por Berlinck (1996) e um deles definido semanticamente em Torres Morais (2007).

Com base nas características semânticas dos verbos bitransitivos e com base no papel temático do OI subcategorizado por eles, Berlinck (1996) assume uma distinção entre verbos que expressam movimento e transferência, a saber: (i) transferência material, (ii) transferência verbal e perceptual, (iii) movimento físico e (iv) movimento abstrato.

O grupo dos verbos que representam transferência material tem por protótipo o verbo dar, e os verbos devolver, emprestar, entregar, fornecer, mandar, oferecer, pagar, etc. são representantes desse grupo cujo esquema representativo é: [+/- animado] $N_{0}+V$ 
$+[(+) /$ - animado $] N_{1}+\{$ a, para, de $\}[+/$ - animado $] N_{2}$. Este grupo de verbo envolve uma transferência material do tipo $\mathrm{N}_{0}$ faz com que $\mathrm{N}_{1}$ seja possuído por $\mathrm{N}_{2}$. Os verbos de transferência material também podem ter uma interpretação inversa, quando $\mathrm{N}_{1}$, ao invés de entrar no domínio da posse de $\mathrm{N}_{2}$, é tirado desse domínio, como ocorre com os verbos: comprar, pedir, etc.

Fazem parte do grupo dos verbos de transferência verbal e perceptual, o qual tem por protótipo o verbo dizer, os verbos anunciar, assegurar, confessar, ensinar, perguntar, entre outros, e apresenta o esquema: [+/-animado] $N_{0}+V+$ [-animado] $N_{l}+$ $\{a$, para $\}$ [+animado] $N_{2}$. Este grupo envolve uma transferência abstrata, no ato comunicativo, pois $\mathrm{N}_{0}$ faz com que $\mathrm{N}_{2}$ possua algum conhecimento, uma ideia ou uma certa percepção; isto explica o porquê de $\mathrm{N}_{2}$ ser sempre [+animado], ou seja, somente uma existência animada pode participar do processo de transferência de conhecimento.

O grupo de verbos de movimento fisico implica uma ideia de transferência, a partir de um movimento físico a fim de uma meta. Este grupo tem como protótipo o verbo levar, e os verbos como acrescentar, conduzir, dirigir, encaminhar, trazer, etc. fazem parte dessa categoria. Em termos sintático-semânticos, a estrutura pode ser descrita como: [+/- animado] $N_{0}+V+$ [+/-animado] $N_{1}+\{$ a, para, em, de $\}$ [+/-animado] $N_{2}$.

$\mathrm{O}$ grupo dos verbos que representam movimento abstrato expressam movimento, porém de sentido abstrato. Esta categoria tem por protótipo o verbo submeter. Fazem parte deste grupo os verbos consagrar, dedicar, destinar, trazer, etc. O esquema que pode representá-lo é: [+/- animado] $N_{0}+V+\left[+/\right.$ animado] $N_{1}+\{$ a, para, em $\}+[+/-$ animado] $N_{2}$.

Sobre os verbos de criação, entre eles, cozinhar, assar, construir, desenhar, preparar, Torres Morais (2007) afirma que, embora não sejam verbos de transferência/movimento tem o argumento OI relacionado ao DP tema, como ocorre com os verbos de transferência/movimento. Em particular, como a autora esclarece, embora o OI dos verbos de transferência/movimento sejam interpretados como alvo/meta e o OI dos verbos de criação como beneficiários, ambos podem receber uma interpretação de recipiente intencional do DP tema.

Adotando a tipologia de Berlinck e Torres Morais, estabelece-se a hipótese geral de que as estratégias de realização do OI estariam condicionadas pela natureza semântica 
do verbo. O resultado percentual obtido das três variantes nos diferentes contextos verbais pode ser visualizado abaixo na Tabela 11:

\begin{tabular}{|c|c|c|c|c|c|c|}
\hline & \multicolumn{2}{|c|}{ Clítico } & \multicolumn{2}{c|}{ Pronome Forte } & \multicolumn{2}{c|}{ Nulo } \\
\hline Transferência Material & $208 / 359$ & $58 \%$ & $21 / 359$ & $5 \%$ & $130 / 359$ & $37 \%$ \\
\hline Transferência Verbal & $330 / 808$ & $41 \%$ & $32 / 808$ & $3 \%$ & $446 / 808$ & $56 \%$ \\
\hline Movimento Físico & $16 / 28$ & $58 \%$ & $1 / 28$ & $3 \%$ & $11 / 28$ & $39 \%$ \\
\hline Movimento Abstrato & $14 / 20$ & $70 \%$ & $0 / 20$ & $0 \%$ & $6 / 20$ & $30 \%$ \\
\hline Criação & $26 / 53$ & $49 \%$ & $7 / 53$ & $13 \%$ & $20 / 53$ & $38 \%$ \\
\hline
\end{tabular}

Tabela 11. Distribuição das variantes segundo os tipos de verbos

A partir dos resultados obtidos na Tabela 11, podemos fazer uma leitura horizontal, da distribuição das variantes em relação a cada um dos tipos de verbos. Assim, percebe-se que os verbos de transferência material favorecem o uso dos clíticos, os quais atingem um percentual de $58 \%$.

Já os verbos de transferência verbal mostram o favorecimento das formas nulas, $56 \%$. Com os verbos de movimento, há um alto índice de ocorrência dos clíticos: no caso dos verbos que expressam movimento físico, o clítico apresenta o percentual de 58\%; com verbos que expressam movimento abstrato, alcança $70 \%$ das ocorrências. As formas nulas ficam, respectivamente, com o percentual de $39 \%$ e $30 \%$.

Finalmente, com os verbos de criação o quadro não é muito diferente e o clítico suplanta outras variantes, com uma frequência de $49 \%$. Vale ressaltar que a variante preposicionada é ainda bastante desfavorecida, tendo tido seu percentual mais elevado no contexto dos verbos de criação, quando atingiu $13 \%$ dos dados. Observe-se a sua total ausência com verbos de movimento abstrato.

No cômputo final, parece, que, com exceção dos verbos de transferência verbal, não houve uma diferença substancial nos demais contextos verbais, nos quais os clíticos alcançaram um percentual mais elevado em relação às outras duas variantes. Como comentamos no capítulo 1, os verbos dicendi favorecem o apagamento dos OIs. 
O Gráfico 2 nos permitirá uma melhor visualização dos resultados obtidos com o conjunto dos verbos, na realização de cada uma das variantes:

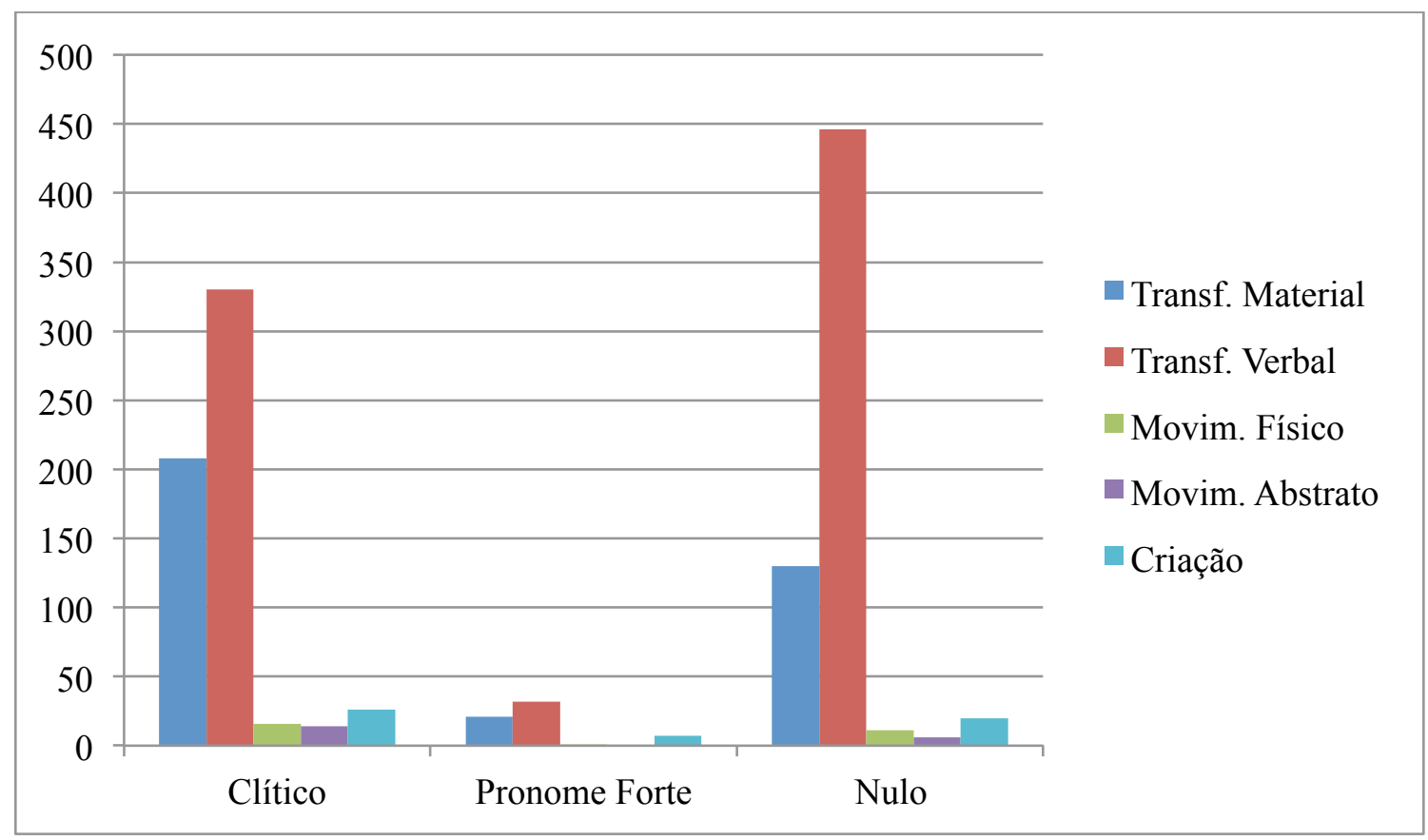

Gráfico 2. As variantes e os tipos de verbos

No entanto, se isolarmos apenas as variantes no uso de $3^{\mathrm{a}}$ pessoa, nos diferentes contextos, teremos o seguinte resultado apresentado na Tabela 12 .

\begin{tabular}{|c|c|c|c|c|c|c|}
\hline & \multicolumn{2}{|c|}{ Clítico } & \multicolumn{2}{c|}{ Pronome Forte } & \multicolumn{2}{c|}{ Nulo } \\
\hline Transferência Material & $73 / 150$ & $48 \%$ & $11 / 150$ & $8 \%$ & $66 / 150$ & $44 \%$ \\
\hline Transferência Verbal & $83 / 218$ & $38 \%$ & $16 / 218$ & $8 \%$ & $119 / 218$ & $54 \%$ \\
\hline Movimento Físico & $4 / 7$ & $57 \%$ & $1 / 7$ & $15 \%$ & $2 / 7$ & $28 \%$ \\
\hline Movimento Abstrato & $3 / 5$ & $60 \%$ & $0 / 5$ & $0 \%$ & $2 / 5$ & $40 \%$ \\
\hline Criação & $9 / 15$ & $60 \%$ & $4 / 15$ & $27 \%$ & $2 / 15$ & $13 \%$ \\
\hline
\end{tabular}

Tabela 12. Distribuição das variantes de $3^{\mathrm{a}}$ pessoa segundo os tipos de verbos 
Os resultados da Tabela 12 mostram que, com as ocorrências das variantes de $3^{\text {a }}$ pessoa, em relação ao verbo de transferência material, temos uma equivalência de percentual entre os clíticos e os nulos, 48\% e 44\%, respectivamente. Já os verbos de transferência verbal mostram o favorecimento das formas nulas, 54\%.

Com os verbos de movimento, há um alto índice de ocorrência dos clíticos: no caso dos verbos que expressam movimento físico, o clítico apresenta o percentual de 57\%; com verbos que expressam movimento abstrato, alcança $60 \%$ das ocorrências. As formas nulas ficam, respectivamente, com o percentual de $28 \%$ e $40 \%$.

Finalmente, com os verbos de criação o quadro não é muito diferente e o clítico suplanta outras variantes, com uma frequência de $60 \%$. Vale ressaltar que a variante preposicionada é ainda bastante desfavorecida, tendo tido seu percentual mais elevado no contexto dos verbos de criação, quando atingiu $27 \%$ dos dados.

Vale destacar que neste contexto verbal a percentagem da variante preposicionada foi superior a de nulo (13\%). Observe-se a sua total ausência com verbos de movimento abstrato.

Ao compararmos as Tabelas 11 e 12 observamos que não houve uma diferença tão significativa, somente em relação aos verbos de transferência material, nos quais temos a predominância do clítico (58\%) com as ocorrências de $2^{\mathrm{a}}$ e a $3^{\mathrm{a}}$ pessoas, enquanto que há uma equivalência entre o clítico e o nulo se consideradas as ocorrências apenas com a $3^{\mathrm{a}}$ pessoa, e também com os verbos de criação o percentual da forma preposicionada sobe para $27 \%$ e a queda do nulo para $13 \%$.

Vejamos o Gráfico 3 que nos permitirá uma melhor visualização dos resultados obtidos com o conjunto dos verbos, na realização de cada uma das variantes somente de $3^{\mathrm{a}}$ pessoa: 


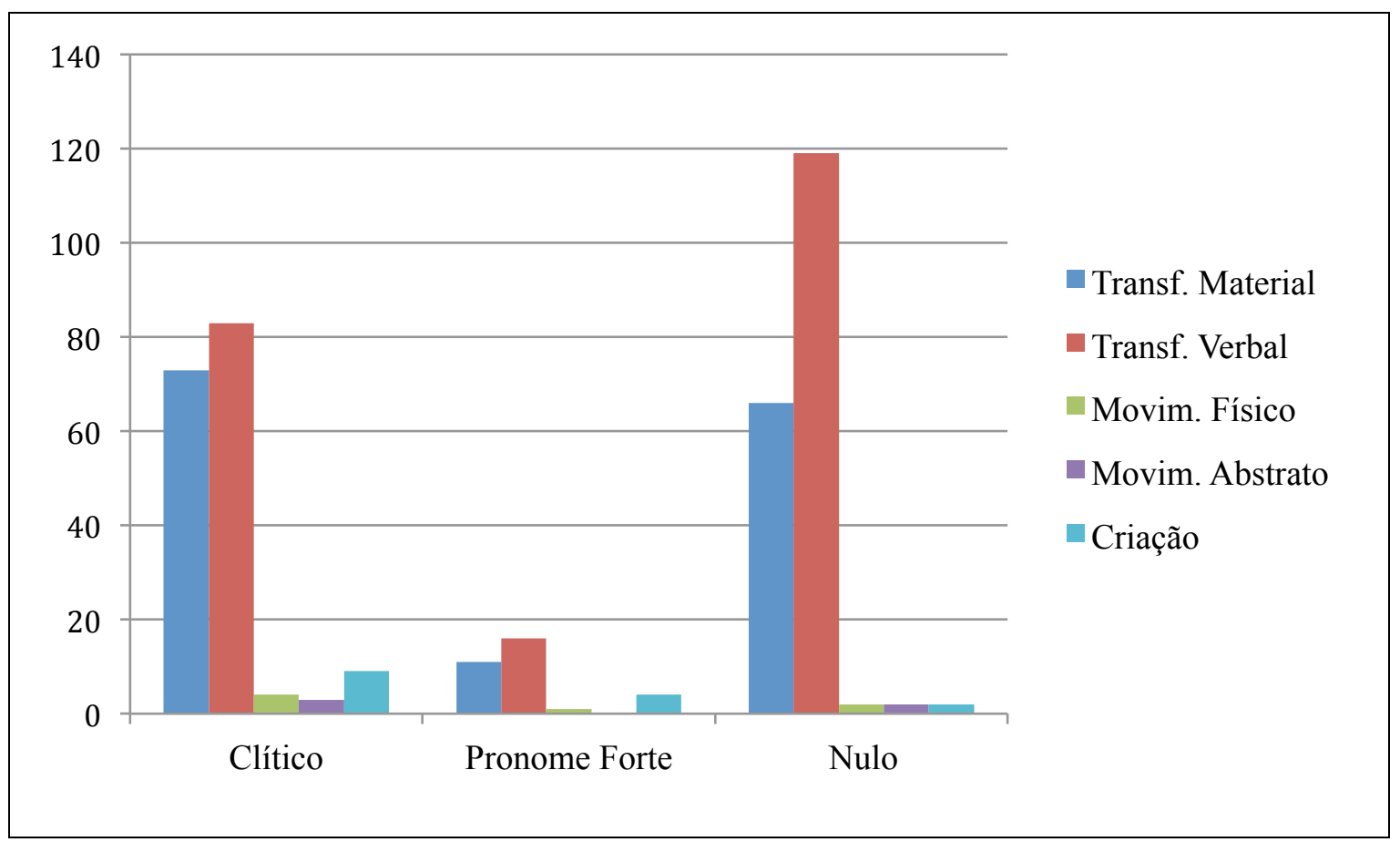

Gráfico 3. As variantes de $3^{\mathrm{a}}$ pessoa e os tipos de verbos

Vejamos a seguir alguns exemplos, selecionados para ilustrar as diferentes variantes, nos diferentes contextos verbais, considerando a $2^{\mathrm{a}}$ e a $3^{\mathrm{a}}$ pessoas:

a - Transferência Material

- Clítico dativo lhe/te:

(31) "Que eu supunha desinteressado... Entregar-lhe todos os meus bens, assim iludir-me... Que malvado, que malvado!" (O Noviço).

(32) "Vem cá; dize-me o que sabes, e dou-teuma molhadura" (O Demônio Familiar).

(33) "Com que direito o senhor me propõe uma redução no capital que eu lhe emprestei?" (O Rei da Vela). 
- Preposição + pronome forte (a/para ele/ela; a/para você):

(34) "Pois olhe, nhanhã tira duas violetas; põe uma nos cabelos, manda outra $\boldsymbol{a}$ ele! Isto de flor!... Uhm!... Faz cócegas no coração" (O Demônio Familiar).

(35) "Darei a você tudo que desejar" (A Moratória).

(36) "E você passou a mão na grana e deu pra ele" (Navalha na Carne).

- Nulo:

(37) "Se Vossa Senhoria quer, posso mandar [Ø] algumas" (O Juiz de Paz da Roça).

(38) "Ela há de casá com seu Borge... Eu dou [Ø] o dote..." (A Capital Federal).

(39) "Então depois eu devolvo [Ø].Só assim" (Vestido de Noiva).

(40) "Está bom, eu entrego [Ø] mas vou dar queixa por escrito" (A Aurora da Minha Vida).

b - Transferência Verbal / Perceptual

- Clítico dativo lhe/te:

(41) "Sua mulher explicar-lhe-á o que aqui me trouxe" (Amor com amor se Paga).

(42) "Pois não te disse já que o meu cocheiro, o Lourenço, amanheceu hoje com uma pontinha de dor de cabeça?" (A Capital Federal).

(43) “A senhora D. Helena não lhefalou agora?” (Lição de Botânica).

(44) "E agora, asseguro-te, não ponho mais os meus pés no Brasil" (Onde Canta o Sabiá).

- Preposição + pronome forte (a/para elelela; a/para você):

(45) "Isto só! Palmo e meio!... Às vezes nhanhã Carlotinha e as amigas zombam deveras! Mas não pergunte $\boldsymbol{a}$ ela, não! Sinhá velha fica maçada" (O Demônio Familiar). 
(46) "Nós vamos voltar para lá, minha filha. Prometo isso a você" (A Moratória).

(47) "Meu marido é que ensina essas coisas para elas" (A Aurora da Minha Vida).

- Nulo:

(48) "Ó cabeça de burro, pois eu não acabo de dizer [Ø] que você é Manoel Maneco Manduba de Mandiroba?" (Como se Fazia um Deputado).

(49) "Promessas tuas? Queres que eu acredite nelas?" "Mas eu juro [Ø]que desta vez..." (O Noviço).

(50) "Responda [ØJem tese, insinue que é melhor ele ser um puro policial” (O Rei da Vela).

(51) "Tantas vezes vim conversar com você sobre ele! Contar [Ø]cada passagem, meu Deus! pois olhe: esse namorado era seu noivo" (Vestido de Noiva).

c - Movimento Físico

(52) “É sim. Um moleque de libré veio entregá-la, haverá meia hora. Aqui está. Quer que lhetraga aqui o cafézinho?" (Sangue Limpo).

(53)“Bem, bem! Vae para a cama que televarei o café” (Flores de Sombra).

(54) “Então tu levas versos a ela sem mano mandar?” (O Demônio Familiar).

(55) “Anda triste? Pois eu trago [Ø] um remédio para alegrá-la” (Onde Canta o Sabiá).

d - Movimento Abstrato

(56) "Há dez dias que lhe consagro todos os meus instantes. Há dez noites que passo velando embevecido ao pé das suas janelas, ditoso por estar mais perto da senhora" (Sangue Limpo).

(57) "A minha carta de bacharel, a qual dedico-lhe, em prova dos muitos sacrifícios que tem feito pela minha felicidade" (Como se Fazia um Deputado) 
e- Verbos de Criação

(58) “Não me diga que está querendo que eu lhefaça as alianças!...” (Intensa Magia).

(59) "Não faz mal; nhanhã fica rica, compra Pedro, manda fazer para ele sobrecasaca preta à inglesa: bota de canhão até aqui; chapéu de castor; tope de sinhá, tope azul no ombro. E Pedro só, traz,zaz, zaz! E moleque da rua dizendo: "Eh, cocheiro de sinhá D. Carlotinha!"”' (O Demônio Familiar).

(60) "O tal que você chamava de sociólogo angélico, ia mandar fazer um samba para eleO pirata jejuador?" (O Rei da Vela).

(61) "Dou as mãos à palmatória, Nhonhô; mas em compensação preparei [Ø] uma surpresa, que há de pôr a mocinha (Imitando.) assim... de beiço caído" (Amor com Amor se Paga).

(62) "Como? Logo hoje, nem bem acabas de chegar?... Mandei fazer [Ø] um jantar todo nosso" (Flores de Sombra).

\subsubsection{Papel temático}

Conforme exposto no capítulo 1, vários estudos têm ressaltado que o OI clítico de $3^{a}$ pessoa têm sido substituído por estratégias alternativas. Berlinck (1997), em particular, ressalta que o sistema pronominal do $\mathrm{PB}$, como um todo, tem passado por um processo bastante profundo de mudança, que inclui como tendência principal a forte diminuição do uso de pronomes clíticos, e o consequente aumento na utilização do pronome tônico e do nulo em função de objeto.

Seus resultados quantitativos mostram ainda que, no caso do OI, o processo de mudança atinge especialmente os casos de $3^{\text {a }}$ pessoa em que este tem um papel temático meta.

Inicialmente, apresentaremos o resultado geral de $2^{\mathrm{a}}$ e $3^{\mathrm{a}}$ pessoas. A próxima tabela apresenta os resultados concernentes aos papéis temáticos meta/alvo e beneficiário: 


\begin{tabular}{|l|c|c|c|c|c|c|}
\hline & \multicolumn{2}{|c|}{ Clítico } & \multicolumn{2}{c|}{ Pronome Forte } & \multicolumn{2}{c|}{ Nulo } \\
\hline Meta/alvo & $571 / 1218$ & $47 \%$ & $54 / 1218$ & $4 \%$ & $593 / 1218$ & $49 \%$ \\
\hline Beneficiário & $23 / 50$ & $46 \%$ & $7 / 50$ & $14 \%$ & $20 / 50$ & $40 \%$ \\
\hline
\end{tabular}

Tabela 13. Distribuição das variantes segundo o papel temático

Os resultados gerais obtidos com $2^{\mathrm{a}}$ e $3^{\mathrm{a}}$ pessoas não revelam diferença significativa em relação ao uso dos clíticos com papel temático meta/alvo e beneficiário, com a percentagem de $47 \%$ e $46 \%$, respectivamente. Em relação ao nulo, temos uma pequena predominância com papel temático meta/alvo em comparação ao beneficiário, $49 \%$ e $40 \%$, respectivamente. Em relação ao pronome forte, o papel temático metalalvo apresenta a percentagem de $4 \%$ e o beneficiário $14 \%$.

Novamente, se considerarmos, porém, apenas o uso de $3^{\text {a }}$ pessoa, obteremos o resultado exposto na Tabela 14:

\begin{tabular}{|l|c|c|c|c|c|c|}
\hline & \multicolumn{2}{|c|}{ Clítico } & \multicolumn{2}{c|}{ Pronome Forte } & \multicolumn{2}{c|}{ Nulo } \\
\hline Meta/alvo & $166 / 383$ & $43 \%$ & $28 / 383$ & $8 \%$ & $189 / 383$ & $49 \%$ \\
\hline Beneficiário & $6 / 12$ & $50 \%$ & $4 / 12$ & $34 \%$ & $2 / 12$ & $16 \%$ \\
\hline
\end{tabular}

Tabela 14. Distribuição das variantes de $3^{\mathrm{a}}$ pessoa segundo o papel temático

Nesta tabela, em relação ao clítico, temos uma pequena predominância no uso com o papel temático beneficiário (50\%) em comparação ao metalalvo (43\%). Em relação ao nulo notamos a predominância do papel temático metalalvo com a percentagem de $49 \%$. Já com o pronome forte temos a predominância do papel temático beneficiário com $34 \%$. Pelo resultado da Tabela 15 é possível depreender que o pronome forte de $3^{\text {a }}$ pessoa é favorecido quando interpretado como beneficiário, enquanto o nulo é favorecido como meta/alvo.

Vejamos alguns exemplos desses usos tanto de $3^{\mathrm{a}}$ pessoa quanto de $2^{\mathrm{a}}$ pessoa. 
a - Papel temático meta/alvo:

(63) “Coitadinho, é preciso comprar-lhe o carrinho!” (O Noviço).

(64) "Paguei uma pinga pra ele. Diz que espera até a estréia... O resto a gente faz sem mesmo..." (Um Grito Parado no Ar).

(65) "Que me importa entregar [Ø] a prova. Eu não sei nada mesmo. O senhor não tem didática" (A Aurora da Minha Vida).

b - Papel temático beneficiário:

(66) "Não me diga que está querendo que eu lhe faça as alianças!..." (Intensa Magia).

(67) "Desenha o Sócrates para mim enquanto eu faço o probleminha de triângulo para você??" (A Aurora da Minha Vida).

(68) "Pensando que você viria muito cansado, fiz [0] a tigela cheia" (A Capital Federal).

\subsubsection{Natureza semântica do OI}

Como observamos no capítulo 1, vários estudos, entre eles, Freire (2000) e Berlinck (1996b), ressaltam a importância do traço animacidade na caracterização do OI. Na nossa análise, fizemos a distinção entre os traços [+animado] [+humano], [+animado] [-humano] e [-humano]. Essa escolha levou em consideração que animais são entidades portadoras do traço [+animado][-humano].

$\mathrm{Na}$ tabela 15, expomos os resultados referentes à realização das variantes em relação ao traço animacidade, levando em conta o uso de $2^{\mathrm{a}}$ e $3^{\mathrm{a}}$ pessoas: 


\begin{tabular}{|c|c|c|c|c|c|c|}
\hline & \multicolumn{2}{|c|}{ Clítico } & \multicolumn{2}{c|}{ Pronome Forte } & \multicolumn{2}{c|}{ Nulo } \\
\hline [+animado] [+humano] & $590 / 1262$ & $47 \%$ & $60 / 1262$ & $4 \%$ & $612 / 1262$ & $49 \%$ \\
\hline [+animado] [-humano] & $2 / 3$ & $67 \%$ & $0 / 3$ & $0 \%$ & $1 / 3$ & $33 \%$ \\
\hline [-animado] & $2 / 3$ & $67 \%$ & $1 / 3$ & $33 \%$ & $0 / 3$ & $0 \%$ \\
\hline
\end{tabular}

Tabela 15. Distribuição das variantes segundo a animacidade

Como era esperado, os dados do corpus revelam que o traço [+ animado][+ humano] é dominante na caracterização do OI anafórico. Assim, encontramos três casos de [+animado] [-humano] e três casos de [-humano]. Considerando o traço [+ animado],temos a seguinte distribuição: 612 casos com as formas nulas (49\%), $590 \mathrm{com}$ as formas clíticas (47\%) e 60 com as formas preposicionadas (4\%).

Isolando o uso de $3^{\text {a }}$ pessoa, observamos que em relação ao traço [+animado] [+humano] os resultados obtidos foram praticamente os mesmos, ou seja, $49 \%$ com as formas nulas, $44 \% \mathrm{com}$ as formas clíticas e $7 \% \mathrm{com}$ as formas preposicionadas, como observamos na Tabela 16 abaixo:

\begin{tabular}{|c|c|c|c|c|c|c|}
\hline & \multicolumn{2}{|c|}{ Clítico } & \multicolumn{2}{c|}{ Pronome Forte } & \multicolumn{2}{c|}{ Nulo } \\
\hline [+animado] [+humano] & $168 / 389$ & $44 \%$ & $31 / 389$ & $7 \%$ & $190 / 389$ & $49 \%$ \\
\hline [+animado] [-humano] & $2 / 3$ & $67 \%$ & $0 / 3$ & $0 \%$ & $1 / 3$ & $33 \%$ \\
\hline [-animado] & $2 / 3$ & $67 \%$ & $1 / 3$ & $33 \%$ & $0 / 3$ & $0 \%$ \\
\hline
\end{tabular}

Tabela 16. Distribuição das variantes de $3^{\mathrm{a}}$ pessoa segundo a animacidade

A seguir, ilustramos os casos em que OI foi marcado com traço [+animado] [+humano]. Vejamos exemplos deste traço com cada variante:

(69) “Peço licença a Vossa Senhoria para lhe oferecer” (O Juiz de Paz da Roça).

(70) "A partir do mês que vem começo a mandar alguma coisa pra vocês" (Intensa Magia).

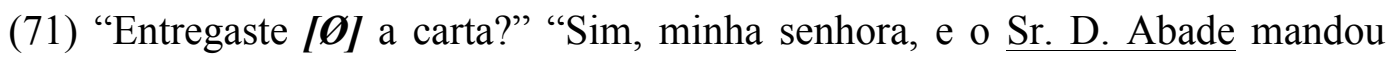
comigo um reverendíssimo, que ficou na sala à espera" (O Noviço). 
No traço [+animado] [-humano], por exemplo um animal, temos os seguintes exemplos:

(72) "Que afrouxe os arreios do animal e que lhe dê agua e um embornal de milho..." (Flores de Sombra).

(73) "Mas, quando o Jujuba (cachorro) se viu solto, recusou-se a gozar o privilégio que lhe queriam dar" (O Rei da Vela).

Já em relação ao traço [-animado] temos os seguintes exemplos:

(74) “A moça de hoje não é a moça do seu tempo. É uma flôr do seculo, colorida, perfumada, artificial, mas que tem entre as pétalas insecto caprichoso que lhe dá vida" (Flores de Sombra).

(75) "Vamos fazer, para ela (jabuticabeira), um rego d'água especial" (A Moratória).

\subsubsection{Pessoa gramatical}

Como observado no capítulo 1, Berlinck (1999) identificou a pessoa gramatical do complemento como um fator importante para a variação e a mudança na expressão do OI no PB. Embora não tenha sido considerada a $1^{\text {a }}$ pessoa em nossa amostra, este fator foi fundamental, uma vez que nosso objetivo foi buscar a movimentação do lhe entre a $2^{\mathrm{a}} \mathrm{e}$ $3^{\mathrm{a}}$ pessoas.

Observa-se na história do PB que os pronomes clíticos acusativos e dativos seguem diferentes rumos. Enquanto as formas acusativas $o, a, o s, a s$, desaparecem do vernáculo, as formas dativas lhe/lhes, migram para a $2^{\mathrm{a}}$ pessoa, sendo usadas tanto como objetos diretos, quanto como objetos indiretos. Assim, disputam com o te a realização das duas funções.

A tabela abaixo mostra os resultados obtidos pela análise das peças de teatro: 


\begin{tabular}{|c|c|c|c|c|c|c|}
\hline & \multicolumn{2}{|c|}{ Clítico } & \multicolumn{2}{c|}{ Pronome Forte } & \multicolumn{2}{c|}{ Nulo } \\
\hline $2^{\mathrm{a}}$ pessoa & $422 / 873$ & $48 \%$ & $29 / 873$ & $4 \%$ & $422 / 873$ & $48 \%$ \\
\hline $3^{\mathrm{a}}$ pessoa & $172 / 395$ & $43 \%$ & $32 / 395$ & $9 \%$ & $191 / 395$ & $48 \%$ \\
\hline
\end{tabular}

Tabela 17. Distribuição das variantes segundo a pessoa gramatical

Os resultados da Tabela 17 indicam que, com a $2^{\mathrm{a}}$ pessoa gramatical, tanto $\mathrm{o}$ clítico como o nulo são frequentes, atingindo o percentual de $48 \%$. Já na $3^{\text {a }}$ pessoa, o uso do nulo é mais frequente, $48 \%$, em comparação com os $43 \%$ dos clíticos. Quanto ao pronome forte, temos uma baixa frequência: apenas $9 \%$ na $3^{\mathrm{a}}$ pessoa, e $4 \%$ na $2^{\mathrm{a}}$ pessoa. Lembramos que as ocorrências na $2^{\mathrm{a}}$ pessoa contemplam os clíticos lhe e o te. Vejam-se os exemplos:

$$
a-2^{a} \text { Pessoa }
$$

- Clítico dativo lhe/te:

(76) "Vossa senhoria há-de permitir que lhepergunte se o noviço Carlos, que fugiu do convento..." (O Noviço).

(77) "Tenho que fazer. Algumas maçadas de homem que se despede de sua vida de garçon. Janto hoje com minha noiva; amanhã parto para a minha fazenda, onde me demorarei alguns dias, e na volta terei o prazer de te anunciar, com todas as formalidades do estilo, em carton porcelaine, sob o competente enveloppe satinée et dorée sur tranche, o meu casamento com a Sra. D. Henriqueta de Vasconcellos" (O Demônio Familiar).

- Preposição + pronome forte (a/para ele/ela; a/para você):

(78) "Eu já mostrei pra você o cartão que ela mandou de Viena com o Palácio da Sissi?" (Intensa Magia). 
- Nulo

(79) "Não! nenhum, posso jurar [Ø]. Isso seria uma loucura. Êle está muito alto para mim. Filho de fidalgos, e eu irmã de um soldado" (Sangue Limpo).

$\mathrm{b}-3^{\mathrm{a}}$ Pessoa

- Clítico dativo lhe/te:

(80) "Escrevi-lhe sempre, mas nada de receber resposta. Muito chorei, porque pensei que ele havia morrido" (O Noviço).

- Preposição + pronome forte (a/para ele/ela; a/para você):

(81) "Isto só! Palmo e meio!... Às vezes nhanhã Carlotinha e as amigas zombam deveras! Mas não pergunte a ela, não! Sinhá velha fica maçada" (O Demônio Familiar).

- Nulo

(82) "Um dia - era perto do Natal - fui à casa dele entregar [Ø] uma encomenda..." (Intensa Magia).

\subsubsection{Fator clítico}

Para expressar melhor o percentual geral de ocorrências dos clíticos te e lhe na $2^{\mathrm{a}}$ pessoa e $3^{\mathrm{a}}$ pessoas, organizamos os resultados que estão expressos na Tabela 18

\begin{tabular}{|c|c|c|}
\hline & \multicolumn{2}{|c|}{ Clítico } \\
\hline Clítico LHE & 454 & $76 \%$ \\
\hline Clítico TE & 140 & $24 \%$ \\
\hline TOTAL & \multicolumn{2}{|c|}{594} \\
\hline
\end{tabular}

Tabela 18. Distribuição das ocorrências dos clítico 
Ao analisarmos essa tabela, observa-se a imensa diferença no número de ocorrências do clítico lhe, com 454 casos, ficando o clítico te com apenas 140 casos. Com isso vale lembrar que tal resultado seria esperável, uma vez que o clítico the contempla os usos de $2^{\mathrm{a}}$ e $3^{\mathrm{a}}$ pessoas, como mostram os exemplos abaixo:

\section{- Clítico LHE:}

(83) "A dona Inácia há de saber que você anda a correr a toda hora para o circo de cavalinhos" "Ah! Foi você que lhe foi dizer?" (Onde Canta o Sabiá).

(84) "Lhe confesso, beijo as mãos da alma dele, porque não é qualquer um não..." (Um Grito Parado no Ar).

- Clítico TE:

(85) "Sim, maquinismo. Eu teexplico. Uma árvore se vira em uma barraca; paus viram-se em cobras, e um homem vira-se em macaco" (O Juiz de Paz da Roça).

(86) "Fico apenas com os dez mil-réis que teemprestei com muita vontade - e sem juros. Quando precisares dêles, vem buscá-los. Cá ficam" (A Capital Federal).

Os percentuais relativos ao uso do clítico lhe de $3^{\mathrm{a}}$ pessoa, em oposição ao uso de $2^{\mathrm{a}}$ pessoa, serão mostrados posteriormente na seção 4.2.3.

\subsubsection{Preposição}

Nosso objetivo, nesta subseção, é avaliar a alternância das preposições $a$ e para nas construções do OI como introdutora dos pronomes fortes.

Estudos, como o de Freire (2000), apresentado no capítulo 1, apontam que o PB e o PE se divergem em vários aspectos, inclusive no que se refere à preposição que antecede tanto um pronome lexical, quanto um $\mathrm{SN}$ anafórico.

Segundo esses estudos, no PB, as preposições $a$ e para estão presentes, porém no PE, não encontramos o uso da preposição para. Assim, segundo Torres Morais (2010), 
no PB, o OI é realizado como um complemento de preposição, ou seja, um complemento oblíquo, introduzido por preposições lexicais (a/para).

No PE, ao contrário, o OI é morfologicamente expresso por marcas casuais de dativo. Talvez seja importante reforçar este ponto. Ou seja, embora ainda tenhamos a preposição a coocorrendo com a preposição para, no contexto dos verbos de transferência e movimento, a preposição $a$ tem, na variante brasileira, um estatuto unicamente lexical, equiparado ao da preposição para.

Com isto, difere do $\mathrm{PE}$, em que $a$ pode ser uma preposição ambígua, a saber: como introdutora de OI, perde seu conteúdo semântico e atua como marcador de caso dativo; como introdutora de outros complementos verbais, tem um estatuto lexical.

Vejamos o que ocorre com as preposições a e para como introdutora de OI anafórico nas peças de teatro.

\begin{tabular}{|c|c|c|}
\hline & \multicolumn{2}{|c|}{ Pronome Forte } \\
\hline Preposição A & 35 & $57 \%$ \\
\hline Preposição PARA & 26 & $43 \%$ \\
\hline TOTAL & \multicolumn{2}{|c|}{61} \\
\hline
\end{tabular}

Tabela 19. Distribuição das ocorrências das preposições

A partir dessa tabela, podemos notar que o número de ocorrência com preposição $a$ é maior, com 35 amostras, enquanto a preposição para conta com 26 ocorrências.

A seguir apresentamos o resultado, exclusivamente, com o uso das variantes de $3^{\mathrm{a}}$ pessoa.

\begin{tabular}{|c|c|c|}
\hline & \multicolumn{2}{|c|}{ Pronome Forte } \\
\hline Preposição A & 18 & $56 \%$ \\
\hline Preposição PARA & 14 & $44 \%$ \\
\hline TOTAL & \multicolumn{2}{|c|}{32} \\
\hline
\end{tabular}

Tabela 20. Distribuição das ocorrências de $3^{\mathrm{a}}$ pessoa com as preposições 
Vamos aos exemplos:

- Preposição A:

(87) "De cabeça erguida! Prometo isso $\boldsymbol{a}$ você" (A Moratória).

(88) "Um dia hei de dizer tudo isto $\boldsymbol{a}$ ela" (A Moratória).

- Preposição PARA:

(89) "Você contou para ele que eu sou louco?" (A Aurora da Minha Vida).

(90) "Houve um momento naquela entrevista em que tive vontade de olhar pra câmera e perguntar pra você por que me puniu com a sua covardia e a sua pretensão; por que não ousou, por que me contaminou, papai???" (Intensa Magia).

\subsubsection{Fatores extralinguísticos}

De acordo com Berlinck (2008), se levarmos em conta a natureza plurilingue das peças de teatro, podemos identificar relações entre usos linguísticos e papéis sociais. Assim sendo, apresentaremos os resultados relevantes dos fatores extralinguísticos deste estudo.

Antes de iniciarmos a discussão dos resultados, lembramos ainda que Berlinck (2008) relata que, em peças de teatro, podemos trabalhar a questão do grau de formalidade, que vai influenciar no uso de determinadas formas linguísticas. O grau de formalidade é resultado da combinação de vários fatores, tais como: "quem fala com quem", "o assunto", “o lugar", "as personagens", “o tipo de peça” (comédia, drama). Esses fatores, conjuntamente, vão favorecer o aparecimento ou a omissão de determinados fenômenos linguísticos.

A seguir, apresentaremos os resultados com os fatores extralinguísticos já explicitados no capítulo 2 . 


\subsubsection{Década}

O percentual das ocorrências das variantes do OI nas peças de teatro, ao longo dos séculos XIX e XX, está apresentado na Tabela 21:

\begin{tabular}{|c|c|c|c|c|c|c|}
\hline & \multicolumn{2}{|c|}{ Clítico } & \multicolumn{2}{c|}{ Pronome Forte } & \multicolumn{2}{c|}{ Nulo } \\
\hline 1831 a 1850 & $199 / 302$ & $66 \%$ & $8 / 302$ & $2 \%$ & $95 / 302$ & $32 \%$ \\
\hline 1851 a 1900 & $181 / 276$ & $66 \%$ & $5 / 276$ & $1 \%$ & $90 / 276$ & $33 \%$ \\
\hline 1901 a 1950 & $153 / 365$ & $42 \%$ & $5 / 365$ & $1 \%$ & $207 / 365$ & $57 \%$ \\
\hline 1951 a 2000 & $61 / 325$ & $18 \%$ & $43 / 325$ & $14 \%$ & $221 / 325$ & $68 \%$ \\
\hline
\end{tabular}

Tabela 21. Distribuição das variantes de $2^{\mathrm{a}}$ e $3^{\mathrm{a}}$ pessoas ao longo das décadas

Comparativamente, a partir da análise dessa tabela, infere-se que no século XIX há um alto índice do clítico, atingindo o percentual de $66 \%$. Situação oposta já se coloca no fim do século XX,quando o clítico aparece com o percentual de $18 \%$. Vale salientar que, no início deste século, ainda tínhamos um número significativo do clítico, com $42 \%$. $\mathrm{Na}$ segunda metade, entretanto já se verifica uma queda drástica em seu uso. Considerando a variante nula, houve o sentido inverso. No início do século XIX, o percentual do nulo era de $32 \%$ e no final do século seguinte atinge $68 \%$, um aumento significativo. Considerando o pronome forte, nota-se, igualmente, aumento percentual, no fim do século XX, com a percentagem de $14 \%$.

Analisemos o Gráfico 4: 


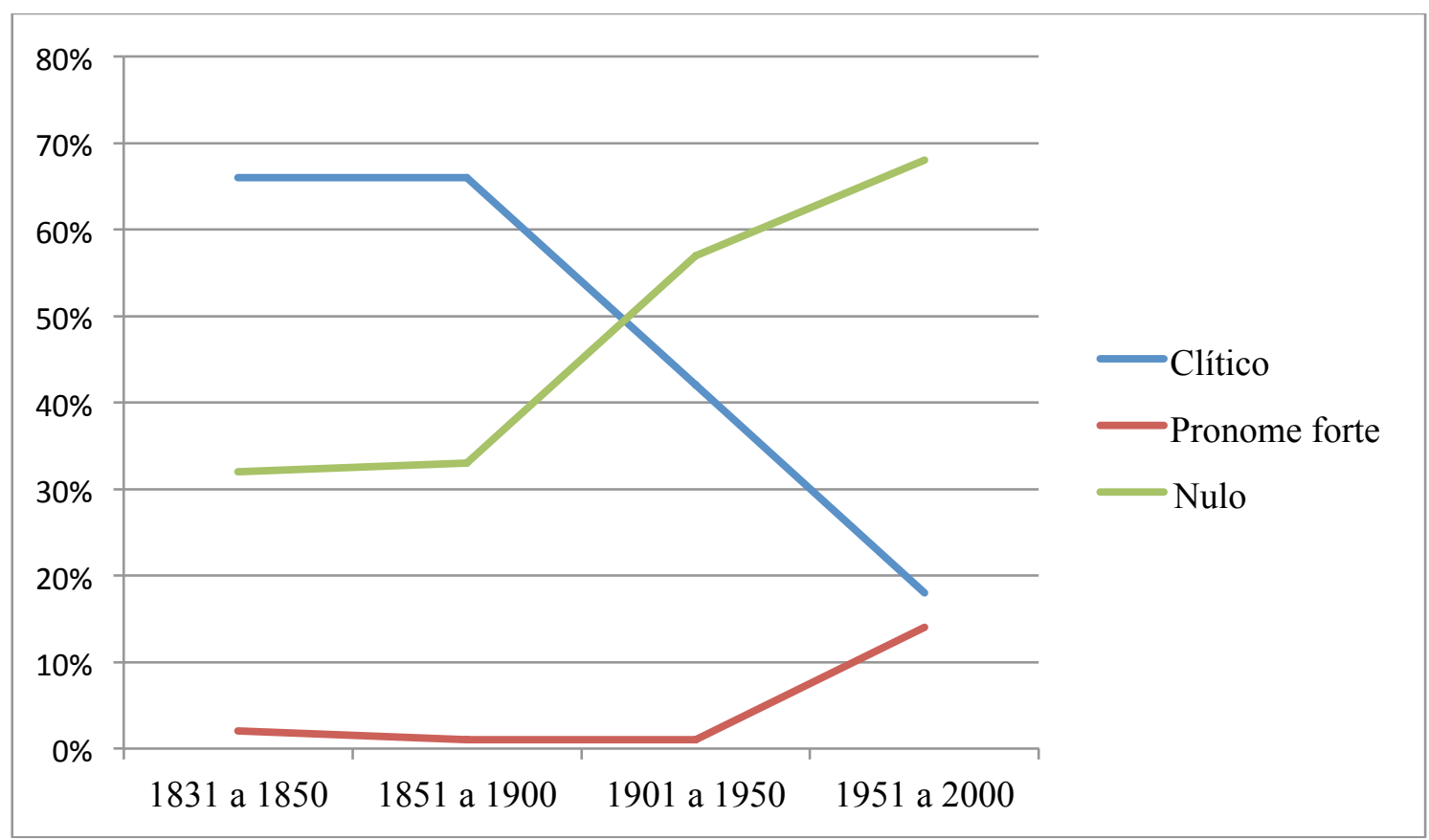

Gráfico 4. As variantes de $2^{\mathrm{a}}$ e $3^{\mathrm{a}}$ pessoas e os séculos

A partir do gráfico acima, nota-se claramente uma gradativa diminuição no uso de clítico no decorrer dos séculos, enquanto há um aumento no uso da variante nula. Em relação ao pronome forte, no final do século XX houve um aumento em seu uso, o que se pode entender que talvez seja uma tendência a partir do século seguinte.

Como os resultados anteriores foram obtidos com as formas pronominais de $2^{\mathrm{a}} \mathrm{e}$ $3^{\mathrm{a}}$ pessoas, mostraremos os resultados apenas com a $3^{\mathrm{a}}$ pessoa.

\begin{tabular}{|c|c|c|c|c|c|c|}
\hline & \multicolumn{2}{|c|}{ Clítico } & \multicolumn{2}{c|}{ Pronome Forte } & \multicolumn{2}{c|}{ Nulo } \\
\hline 1831 a 1850 & $63 / 112$ & $56 \%$ & $7 / 112$ & $6 \%$ & $42 / 112$ & $38 \%$ \\
\hline 1851 a 1900 & $59 / 91$ & $65 \%$ & $3 / 91$ & $3 \%$ & $29 / 91$ & $32 \%$ \\
\hline 1901 a 1950 & $46 / 100$ & $46 \%$ & $3 / 100$ & $3 \%$ & $51 / 100$ & $51 \%$ \\
\hline 1951 a 2000 & $4 / 92$ & $4 \%$ & $19 / 92$ & $21 \%$ & $69 / 92$ & $75 \%$ \\
\hline
\end{tabular}

Tabela 22. Distribuição das variantes de $3^{\mathrm{a}}$ pessoa ao longo dos séculos 
O gráfico a seguir ilustra o percurso das variantes de $3^{\mathrm{a}}$ pessoa através dos séculos.

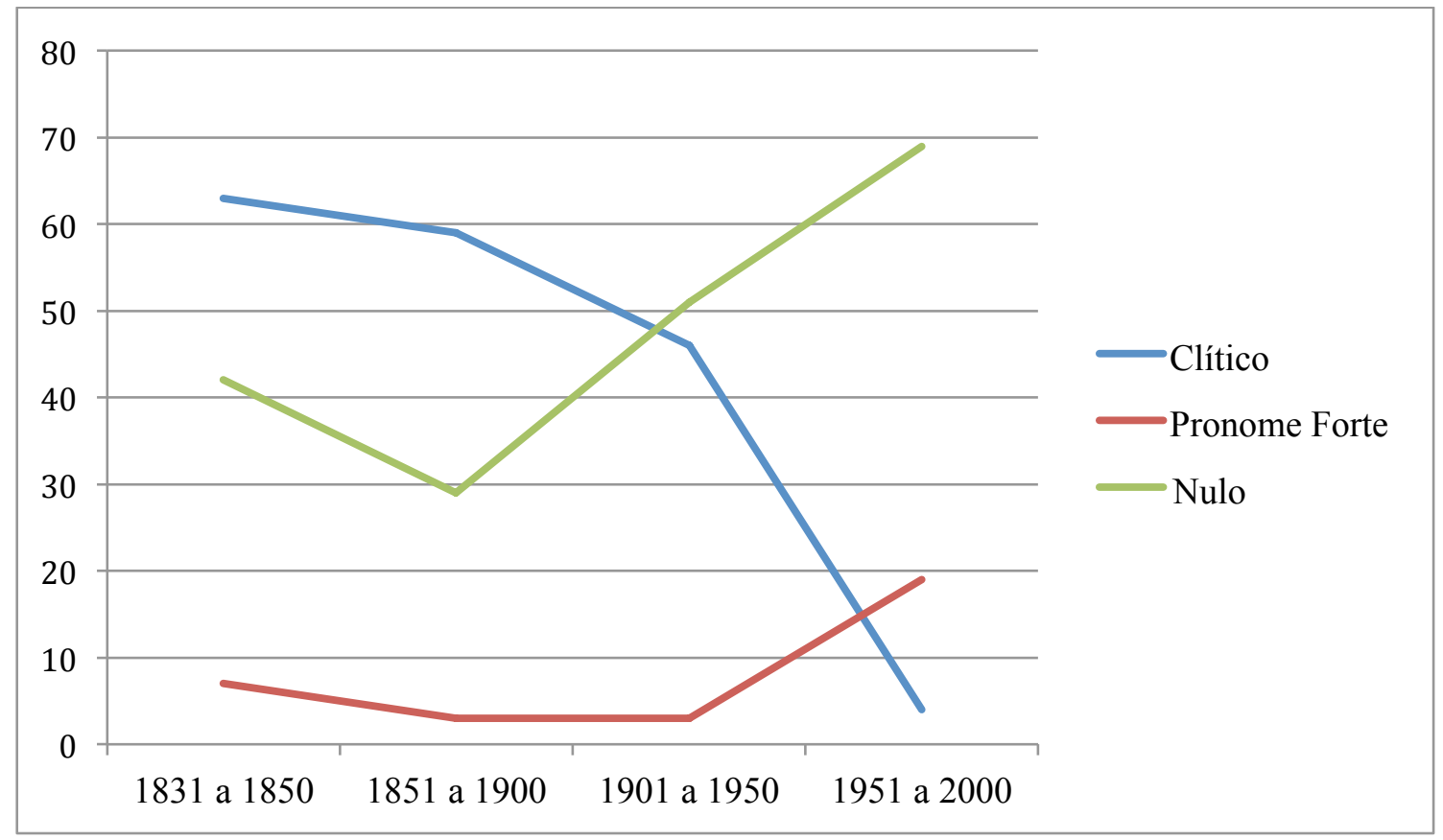

Gráfico 5. As variantes de $3^{\mathrm{a}}$ pessoa e os séculos

Observando o Gráfico 5, no qual que isolamos clítico de $3^{\mathrm{a}}$ pessoa, constatamos a queda acentuada do lhe, o qual atinge o percentual de apenas $4 \%$ no final do século XX. Ou seja, trata-se de um percentual residual, que de acordo com o modelo de mudança que estamos assumindo, não mais representaria uma evidência positiva para as criançasna fase de aquisição da língua materna.

Como vimos pelos vários estudos que mencionamos (cf. Cap.1), os clíticos dativos de $3^{\text {a }}$ pessoa são adquiridos via escrita formal e usados unicamente nessas situações.

Também esperados eram os resultados com a estratégia das formas nulas. Nossos dados mostram que a variante nula, neste mesmo período, atinge o percentual de $75 \%$. Há ainda um aumento significativo na preposicionada, a qual atinge $21 \%$.

Aqui, remetemos ao estudo de Torres Morais (2010), apresentado na seção 1.6, no qual a pesquisadora observa que o OI nulo de $3^{\text {a }}$ pessoa é licenciado tanto no PE quanto no $\mathrm{PB}$, porém sua frequência é maior na variante brasileira. Embora não totalmente 
comprovado, tal fato competição pode estar relacionada à perda dos clíticos dativos no PB.

Escolhemos, para ilustrar este fator, apenas alguns exemplos das variantes mais produtivas, a saber: clítico no século XIX e nulo no século XX.

(91) "Primo, você também é frade? Já lhe deram também um carrinho de prata com cavalos de ouro?” (O Noviço).

(92) "Sim, o senhor educou-a bem... ensinou-lhe muita coisa" (A Capital Federal).

(93) “Antes, porém, de nos despedirmos, desejava dizer [Ø] uma coisa e perguntar [Ø] outra. Direi [Ø] primeiramente que ignoro se há tal paixão da parte de seu sobrinho; em segundo lugar, perguntarei [Ø] se na Suécia êstes pedidos são usuais" (Lição de Botânica).

(94) "O processo de nulidade. Não pude me controlar; não tive coragem de dizer [Ø]. Mamãe! Não queria que você sofresse. Não posso vê-la sofrer!” (A Moratória).

No final do século XX, houve um aumento das formas preposicionadas:

(95) "Em vez de chorar, eu perguntei para ele porque tinha rasgado. Eu expliquei para ele que eu queria prestar uma homenagem pois era, além do meu aniversário, dia da Bandeira" (A Aurora da Minha Vida).

\subsubsection{Gênero das peças}

Como dito anteriormente, neste estudo consideramos dois tipos de gêneros das peças analisadas: comédia e drama. Em um total de 17 peças de teatro, reunidas para compor o corpus deste trabalho, 13 são do gênero comédia e 4 são do gênero drama. Entretanto, acreditamos que esta diferença não enviese nossos resultados. Como comentamos, no capítulo 2, o mais relevante quando se toma como corpus o gênero dramático, é o fato de que as peças têm um caráter dialógico e plurilíngue, nas quais podemos observar, no conjunto das falas das personagens, uma tentativa da reprodução 
da língua falada, em uma determinada época, em diferentes contextos (cf. Berlinck 2008). A tabela 23 expõe os resultados gerais.

\begin{tabular}{|c|c|c|c|c|c|c|}
\hline & \multicolumn{2}{|c|}{ Clítico } & \multicolumn{2}{c|}{ Pronome Forte } & \multicolumn{2}{c|}{ Nulo } \\
\hline Comédia & $494 / 944$ & $52 \%$ & $41 / 944$ & $5 \%$ & $409 / 944$ & $43 \%$ \\
\hline Drama & $100 / 324$ & $31 \%$ & $20 / 324$ & $6 \%$ & $204 / 324$ & $63 \%$ \\
\hline
\end{tabular}

Tabela 23. Distribuição das variantes segundo o gênero das peças de teatro

Analisando a Tabela 23, há uma frequência maior de clítico nas comédias do que nas peças dramáticas, $52 \%$ e $31 \%$, respectivamente. Da mesma forma, há um uso mais frequente das formas nulas nas peças dramáticas, a saber, $63 \%$. Em ambos os tipos de peças a estratégia dos pronomes fortes preposicionados ainda é incipiente. Ou seja, temos uma equivalência de $5 \%$ e $6 \%$.

Pela análise dos resultados, observa-se que a nossa expectativa parece não se ter confirmado. Esperava-se que os clíticos seriam mais frequentes no gênero drama, por serem consideradas como "mais formais". Porém, como Berlinck (2008) ressalta, o pesquisador dificilmente poderá taxar um dado texto como "formal" ou informal" de maneira definitiva, já que toda avaliação é feita a partir das relações que o texto analisado mantém com um conjunto de outros textos, pertencentes ou não ao mesmo gênero.

Os exemplos abaixo ilustram o uso do clítico nas comédias e do nulo no drama:

(96) "Eu lhe mostrarei, deixe estar" (O Juiz de Paz da Roça).

(97) "Vou escrever-lhe! Estou quase certa de que ela vem!" (O Demônio Familiar)

(98) "Se a senhora visse como ele se zanga, quando eu falo [Ø] no desembargador!" (Vestido de Noiva).

Com relação aos resultados de $3^{\text {a }}$ pessoa, não obtivemos resultados muito distintos aos casos de $2^{\mathrm{a}}$ e $3^{\mathrm{a}}$. 


\subsubsection{Classe social}

Classificamos as personagens de cada peça de teatro em populares e não populares. Como mencionamos no capítulo 2, consideram-se como personagens populares o pequeno fazendeiro, escrivão, soldado, pequeno comerciante, cocheiro e pessoas de classe média. Como não populares seriam grandes fazendeiros, major, tenente-coronel, abade, juiz de paz, barão, entre outros.

A Tabela 24 apresenta os seguintes resultados.

\begin{tabular}{|c|c|c|c|c|c|c|}
\hline & \multicolumn{2}{|c|}{ Clítico } & \multicolumn{2}{c|}{ Pronome Forte } & \multicolumn{2}{c|}{ Nulo } \\
\hline Popular & $237 / 615$ & $38 \%$ & $39 / 615$ & $7 \%$ & $339 / 615$ & $55 \%$ \\
\hline Não Popular & $357 / 653$ & $55 \%$ & $22 / 653$ & $3 \%$ & $274 / 653$ & $42 \%$ \\
\hline
\end{tabular}

Tabela 24. Distribuição as variantes segundo a classe social das personagens

Podemos observar nesta tabela que entre as personagens populares há um alto índice de nulo com um percentual de $55 \%$, seguido pelo clítico com o percentual de $38 \%$ e pronome forte, com 7\%. Por outro lado, entre as personagens não populares o índice de clítico é maior com percentual de $55 \%$, seguido do nulo com $42 \%$ e pronome forte com $3 \%$.

Pelo resultado desse cruzamento, parece não se ter realizado a expectativa de que as personagens populares não fazem uso dos clíticos, por ser uma estratégia utilizada por pessoas que tiveram um acesso mais efetivo às formas de prestígio. Como se sabe, os dramaturgos e escritores, de um modo geral, tentam utilizar as marcas dialetais, sejam elas de natureza social ou geográfica, na caracterização de suas personagens populares.

Uma explicação pode estar em que nossos dramaturgos, principalmente os do século XIX e primeiras décadas do século XX, ainda estivessem de alguma forma presos a um modelo de língua escrita, mesmo na caracterização de seus personagens populares.

Vejamos alguns exemplos representativos do uso das três estratégias de realização do OI na fala de personagens populares: 
(99) Escravo: "Nhanhã foi dizer [Ø]?... Pois não!... Esta Pedro não engole" (O Demônio Familiar).

(100) Irmã de soldado: “Olhe, Vitorino; êle não se há de demorar, sairá imediatamente. Quero só dizer-lhe duas palavras... que fuja daqui, que não me procure, que eu o aborreço de morte... Ah! se soubessem como eu tremi por êle, quando, há pouco, Rafael percebeu o que me dizia a tia Onistalda! Fiquei sem uma pinga de sangue no corpo. Faça o que estou a pedir... nada custa... Eu sempre fui sua amiga, não é? Porque não há de fazer-me esse favor?” (Sangue Limpo).

(101) Filha de pequeno fazendeiro: "Espero que o senhor não fale [Ø] nada. Deixe ele trabalhar. Aos poucos a situação melhora. O Marcelo não terá nada a perder, mesmo se voltarmos para a fazenda..." (A Moratória).

(102) Mulher do interior: "Vai, vai dizê a êle que não tô zangada!" (A Capital Federal).

Com relação aos resultados de $3^{\mathrm{a}}$ pessoa, observamos a mesma tendência aos resultados de $2^{\mathrm{a}}$ e $3^{\mathrm{a}}$.

\subsubsection{Gênero das personagens}

Classificamos as personagens das peças em feminino e masculino. Seriam as personagens masculinas ou femininas a usarem as formas clíticas ou nulas? Vejamos os resultados das tabelas 25 e 26 a seguir:

\begin{tabular}{|c|c|c|c|c|c|c|}
\hline & \multicolumn{2}{|c|}{ Clítico } & \multicolumn{2}{c|}{ Pronome Forte } & \multicolumn{2}{c|}{ Nulo } \\
\hline Masculino & $376 / 754$ & $49 \%$ & $38 / 754$ & $6 \%$ & $340 / 754$ & $45 \%$ \\
\hline Feminino & $218 / 514$ & $42 \%$ & $23 / 514$ & $5 \%$ & $273 / 514$ & $53 \%$ \\
\hline
\end{tabular}

Tabela 25. Distribuição das variantes segundo o gênero das personagens 


\begin{tabular}{|c|c|c|c|c|c|c|}
\hline & \multicolumn{2}{|c|}{ Clítico } & \multicolumn{2}{c|}{ Pronome Forte } & \multicolumn{2}{c|}{ Nulo } \\
\hline Masculino & $98 / 233$ & $42 \%$ & $21 / 233$ & $10 \%$ & $114 / 233$ & $48 \%$ \\
\hline Feminino & $74 / 162$ & $46 \%$ & $11 / 162$ & $6 \%$ & $77 / 162$ & $47 \%$ \\
\hline
\end{tabular}

Tabela 26. Distribuição das variantes de $3^{\mathrm{a}}$ pessoa segundo o gênero das personagens

Pelas tabelas, verifica-se que, se considerarmos os dados de $2^{\mathrm{a}}$ e $3^{\mathrm{a}}$ pessoas, as personagens masculinas utilizam mais o clítico (49\%), já se considerarmos somente a $3^{\text {a }}$ pessoa utilizam mais a forma nula (48\%). Quanto às personagens femininas o nulo é mais frequente, tanto com $2^{\mathrm{a}}$ e $3^{\mathrm{a}}$ pessoas, quanto com a $3^{\mathrm{a}}$ pessoa, com a percentagem de $53 \%$ e $47 \%$, respectivamente.

$\mathrm{O}$ que se pode concluir pelo resultado é que os autores tenham entendido que as mulheres poderiam ser menos conservadoras. Por outro lado, elas podem ser caracterizadas como pessoas de menor escolaridade do que menos cultas do que os homens.

A seguir, apresentamos alguns exemplos com o uso do clítico pelas personagens masculinas e com o uso nulo pelas personagens femininas:

(103) Rafael: "Pobre criatura! Bem vejo que as minhas palavras não dão consolação, mas é só o que tenho para oferecer-lhe. O combate não tarda, e sinto-me sem fôrças para lutar. Que martírio não é vê-la definhar assim, e beber suas lágrimas! Antes quisera ter adiante de mim as forças tôdas de Artigas e Frutuoso Rivera. Meu Deus, afastai desta casa alguma desgraça" (Sangue Limpo).

(104) Miguel: "Enquanto o senhor fazia a corte à minha metade, eu constipava-me no seu galinheiro à espera da sua. Mas já lhe disse que pode ficar tranqüilo; o divino Platão velava por nós. Sua mulher explicar-lhe-á o que aqui me trouxe" (Amor com Amor se Paga).

(105) Amanda: "Eu sei, meu querido, eu sei... Mas eu dei [Ø] um cheque post datado... Não tenho culpa que eles tenham ido descontar..." (Um Grito Parado no Ar). (106) Mãe: “É isso que aquela avó ensinou [Ø]?” (A Aurora da Minha Vida). 
Em linhas gerias, os resultados obtidos pela análise das variantes do OI com cada fator revelaram o que era esperado, se tomamos como ponto de referência os estudos apresentados no capítulo 1 .

Dando continuidade à nossa análise das amostras coletadas nas peças de teatro, apresentaremos mais alguns resultados, pois, como sabemos, o programa Goldvarb permite-nos efetuar o cruzamento das variantes com fatores distintos.

4.2 Resultados dos cruzamentos

Nesta seção, apresentaremos os cruzamentos que nos pareceram mais relevantes. Organizamos os cruzamentos de forma a considerar fatores de natureza linguística e extralinguística. Num primeiro momento, analisaremos um fator extralinguístico com fatores linguísticos (subseção 4.2.1). Num segundo momento, analisaremos fatores linguísticos com outros fatores linguísticos (subseções 4.2.2 e 4.2.3).

\subsubsection{O fator década}

Nesta seção, destacaremos o cruzamento das décadas com os fatores: tipos verbo, pessoa gramatical, fator clítico e preposição introdutora do pronome forte. Como exposto no capítulo 2, buscamos traçar o percurso do OI no tempo e os fatores que atuam na realização das variantes selecionadas. E que, possivelmente, possam indicar um processo de mudança no PB.

\subsubsection{O fator década e o contexto verbal}

Primeiramente, cruzaremos as décadas com os cinco verbos considerados neste estudo. O resultado dos dados, distribuídos de acordo com as três formas de realização do OI, é apresentado a seguir. Observe-se que na Tabela 20 as décadas foram concentradas em dois períodos: $1^{\mathrm{a}}$ metade do século XIX que corresponde às décadas de 1830-1850 e segunda metade do século XX que corresponde às décadas de 1951-2000, para destacaras ocorrências desses dois períodos que se mostram mais relevantes a este estudo. Nesta tabela levamos em conta $2^{\mathrm{a}}$ e $3^{\mathrm{a}}$ pessoas. 


\begin{tabular}{|c|c|c|c|c|c|c|c|c|c|c|}
\hline Verbo & \multicolumn{2}{|c|}{ Transf. Material } & \multicolumn{2}{|c|}{ Transf. Verbal } & \multicolumn{2}{c|}{ Movim. Físico } & \multicolumn{2}{c|}{ Movim.Abstrato } & \multicolumn{2}{c|}{ Criação } \\
\hline Década & $1^{\mathrm{a} X I X}$ & $2^{\mathrm{a}} \mathrm{XX}$ & $1^{\mathrm{a} X I X}$ & $2^{\mathrm{a} X X}$ & $1^{\mathrm{a} X I X}$ & $2^{\mathrm{a} X X}$ & $1^{\mathrm{a} X I X}$ & $2^{\mathrm{a} X X}$ & $1^{\mathrm{a} X I X}$ & $2^{\mathrm{a}} \mathrm{XX}$ \\
\hline Clítico & $71 \%$ & $27 \%$ & $67 \%$ & $13 \%$ & $33 \%$ & $33 \%$ & $67 \%$ & $33 \%$ & $30 \%$ & $53 \%$ \\
\hline Pronome Forte & $2 \%$ & $18 \%$ & $2 \%$ & $11 \%$ & $17 \%$ & $0 \%$ & $0 \%$ & $0 \%$ & $10 \%$ & $27 \%$ \\
\hline Nulo & $27 \%$ & $55 \%$ & $31 \%$ & $76 \%$ & $50 \%$ & $67 \%$ & $33 \%$ & $67 \%$ & $60 \%$ & $20 \%$ \\
\hline
\end{tabular}

Tabela 27. Frequência das variantes segundo as décadas e os tipos de verbos

Em relação aos verbos de transferência material, a tabela revela um alto percentual de uso dos clíticos, 71\%, no início do século XIX e uma queda acentuada no final do século XX, com apenas $27 \%$ das realizações. Com a variante pronome forte, no início do século XIX a frequência é de somente 2\%. Já no final do século XX há um aumento na sua realização, com $18 \%$ do total dos dados. Já o nulo, no início do século XIX, apresenta a percentagem de $27 \%$, tendo sua frequência aumentada no final do século XX para $55 \%$.

Observamos o mesmo fenômeno com os verbos de transferência verbal, como ocorreu com os verbos de transferência material. O clítico é muito frequente no início do século XIX, atingindo percentual de $67 \%$. No final do século XX, porém, percentual diminui drasticamente para $13 \%$.

Com o pronome forte, a percentagem é de $2 \%$ no início do século XIX e de $11 \%$ no final do século XX. Quanto ao pronome nulo, novamente temos um aumento percentual ao longo do tempo: 31\% na primeiras décadas do século XIX e o alto índice de $76 \%$, finalizando o século XX.

Em relação aos verbos de movimento físico observamos a mesma frequência de clítico nos dois séculos, 33\%. Com relação ao pronome forte, no início do século XIX a frequência é de $17 \%$, não havendo nenhuma ocorrência no final do século XX. As formas nulas apresentam um pequeno aumento: no começo do século XIX contava com $50 \%$ e finaliza o século XX atingindo $67 \%$.

Com os verbos de movimento abstrato, a frequência de clítico diminuiu, começando o século XIX com $67 \%$, e caindo para $33 \%$ ao final do século XX. Por outro 
lado, a frequência de nulo aumenta, começando o século XIX com a percentagem de $33 \%$, e atingindo $67 \%$ no final do século XX. Não houve nenhuma ocorrência desse tipo de verbo com pronome forte.

Já com os verbos de criação, notamos o movimento inverso: a frequência de clítico aumenta, com 30\% no início do século XIX, e 53\% no final do século XX. Por sua vez, a frequência das formas nulas diminui. O alto percentual de $60 \%$ do século XIX, se reduz aos $20 \%$ do final do século passado. Com o pronome forte houve um pequeno aumento, começa com 10\% no início do século XIX, chegando a $27 \%$ no final do século XX.

Se considerarmos somente as ocorrências de $3^{\mathrm{a}}$ pessoa, teremos o seguinte resultado apresentado na Tabela 28.

\begin{tabular}{|c|c|c|c|c|c|c|c|c|c|c|}
\hline Verbo & \multicolumn{2}{|c|}{ Transf. Material } & \multicolumn{2}{|c|}{ Transf. Verbal } & \multicolumn{2}{c|}{ Movim. Físico } & \multicolumn{2}{c|}{ Movim.Abstrato } & \multicolumn{2}{c|}{ Criação } \\
\hline Década & $1^{\mathrm{a} X I X}$ & $2^{\mathrm{a}}$ XX & $1^{\mathrm{a} X I X}$ & $2^{\mathrm{a}}$ XX & $1^{\mathrm{a} X I X}$ & $2^{\mathrm{a} X X}$ & $1^{\mathrm{a} X I X}$ & $2^{\mathrm{a} X X}$ & $1^{\mathrm{a} X I X}$ & $2^{\mathrm{a} X X}$ \\
\hline Clítico & $60 \%$ & $6 \%$ & $55 \%$ & $4 \%$ & $33 \%$ & $0 \%$ & $50 \%$ & $0 \%$ & $50 \%$ & $0 \%$ \\
\hline Pronome Forte & $5 \%$ & $19 \%$ & $5 \%$ & $20 \%$ & $33 \%$ & $0 \%$ & $0 \%$ & $0 \%$ & $50 \%$ & $50 \%$ \\
\hline Nulo & $35 \%$ & $75 \%$ & $40 \%$ & $76 \%$ & $34 \%$ & $0 \%$ & $50 \%$ & $0 \%$ & $0 \%$ & $50 \%$ \\
\hline
\end{tabular}

Tabela 28. Frequência das variantes de $3^{\mathrm{a}}$ pessoa segundo as décadas e os tipos de verbos

Em relação aos verbos de transferência material, a tabela revela que $60 \%$ dos dados ocorrem com a variante clítico no início do século XIX, e que tal percentual configura um patamar residual de $6 \%$ no final do século XX.

Com a variante pronome forte, o que temos é uma frequência de 5\% no início do século XIX, e 19\% no final do século XX. Já o nulo se revela a estratégia preferida ao fim do percurso temporal: no início do século XIX, apresenta a percentagem de 35\%.No final do século XX, aparece em $75 \%$ dos casos.

Observamos o mesmo fenômeno com os verbos de transferência verbal. O clítico é muito frequente no início do século XIX com 55\%, mas esta frequência cai drasticamente no final do século XX, atingindo um percentual de $4 \%$. Com o pronome forte, a percentagem é de 5\% no início do século XIX e de $20 \%$ no final dos anos 20 . 
Quanto aos nulos, o seu número também aumentou: o século XIX começa com $40 \%$; século XX com o alto índice de $76 \%$.

Em relação aos verbos de movimento físico, observamos a mesma frequência de clítico, pronome forte e nulo, 33\%, no início do século XIX. Não tivemos dados nas décadas finais do século XX.

Com os verbos de movimento abstrato, a frequência de clítico e forma nula é igual, ou seja, 50\% no começo do século XIX. Não houve nenhuma ocorrência da forma preposicionada. De forma semelhante ao que ocorre no contexto dos verbos de movimento físico, não encontramos nenhuma ocorrência de OIs no final do século XX.

Já com os verbos de criação, vemos que, no início do século XIX, a frequência de clítico e pronome são iguais, atingindo $50 \%$ dos dados. Não encontramos OI nulos. No final do século XX, o pronome forte e o nulo aparecem com a mesma percentagem, $50 \%$, sem ocorrências da forma clítica.

Para ilustrar o percurso do clítico lhe de $3^{\mathrm{a}}$ pessoa ao longo dos séculos e, segundo os tipos de verbos, apresentamos o gráfico 6:

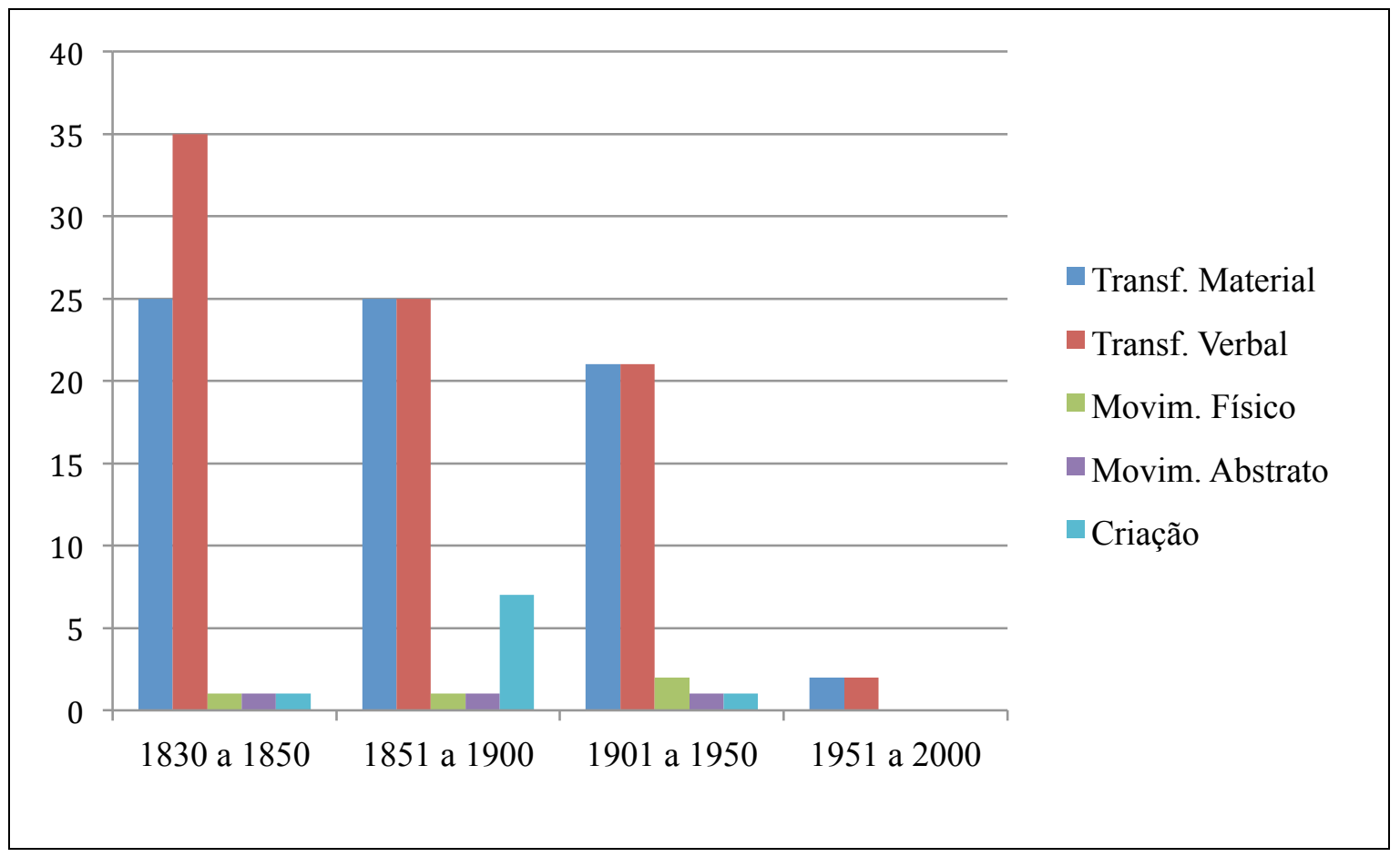

Gráfico 6. O clítico lhe de $3^{\mathrm{a}}$ pessoa segundo os verbos e os século 
4.2.1.2 O fator década e a pessoa gramatical

Nas próximas tabelas mostramos o cruzamento das décadas com a pessoa gramatical, separando a $2^{\text {a }}$ pessoa (tabela 29 ) e da $3^{\text {a }}$ pessoa ( tabela 30 ).

\begin{tabular}{|c|c|c|c|c|c|c|c|c|}
\hline & \multicolumn{7}{|c|}{$3^{\text {a }}$ Pessoa } \\
\hline Pessoa & \multicolumn{2}{|c|}{$1831-1850$} & \multicolumn{2}{|c|}{$1851-1900$} & $1901-1950$ & $1951-2000$ \\
\hline Décadas & 62 & $56 \%$ & 59 & $65 \%$ & 47 & $47 \%$ & 4 & $4 \%$ \\
\hline Clítico & 7 & $6 \%$ & 3 & $3 \%$ & 3 & $3 \%$ & 19 & $21 \%$ \\
\hline Pronome Forte & 42 & $38 \%$ & 29 & $32 \%$ & 51 & $50 \%$ & 69 & $75 \%$ \\
\hline Nulo & & & & & & & & \\
\hline
\end{tabular}

Tabela 29. Distribuição das variantes de $3^{\mathrm{a}}$ pessoa segundo as décadas

\begin{tabular}{|c|c|c|c|c|c|c|c|c|}
\hline Pessoa & \multicolumn{7}{|c|}{$2^{\text {a }}$ Pessoa } \\
\hline Décadas & \multicolumn{2}{|c|}{$1831-1850$} & $1851-1900$ & $1901-1950$ & \multicolumn{2}{c|}{$1951-2000$} \\
\hline Clítico & 137 & $71 \%$ & 122 & $66 \%$ & 106 & $40 \%$ & 57 & $25 \%$ \\
\hline Pronome Forte & 1 & $1 \%$ & 2 & $1 \%$ & 2 & $1 \%$ & 24 & $10 \%$ \\
\hline Nulo & 53 & $28 \%$ & 61 & $33 \%$ & 156 & $59 \%$ & 152 & $65 \%$ \\
\hline
\end{tabular}

Tabela 30. Distribuição das variantes de $2^{\mathrm{a}}$ pessoa segundo as décadas

De um modo geral, as Tabela 29 e 30 revelam que o percentual dos clíticos foi se reduzindo ao longo das décadas, tanto na referência à $2^{\mathrm{a}}$ pessoa quanto à $3^{\mathrm{a}}$ pessoa. Aqui vale lembrar que tabelas anteriores, como as Tabelas 22 e 23, mostram esse fenômeno da redução dos clíticos.

Porém, o número de clíticos de $2^{\mathrm{a}}$ pessoa é maior que o número de clíticos na $3^{\mathrm{a}}$ pessoa, igualmente apresentado na Tabela 18, pois aqui também temos o lhe e o te computados conjuntamente na $2^{\mathrm{a}}$ pessoa, em oposição ao uso exclusivo do the na $3^{\mathrm{a}}$ 
pessoa. Se atentarmos para o final do século XX, a percentagem de clítico de $3^{\text {a }}$ pessoa é de somente $4 \%$. Por sua vez, o clítico de $2^{\mathrm{a}}$ pessoa ainda atinge o percentual de $25 \%$ das ocorrências, ao final do mesmo século.

Em contrapartida, o percentual de nulo foi aumentando ao longo das décadas nas duas pessoas gramaticais, atingindo a frequência de $65 \%$ na $2^{\mathrm{a}}$ pessoa e $75 \%$ na $3^{\mathrm{a}}$ pessoa. Já de pronome forte aumenta no final do século XX também nas duas pessoas, $10 \%$ com a $2^{\mathrm{a}}$ pessoa e $21 \%$ com a $3^{\mathrm{a}}$ pessoa.

O próximo fator a ser analisado é o clítico que, como observamos, tem uma relação com as pessoas analisadas acima.

\subsubsection{O fator década e o clítico}

Nessa tabela mostraremos as ocorrências do fator clítico no decorrer dos séculos. Ressaltando que estamos analisando o cruzamento do fator clítico com as décadas e não a variante clítico.

\begin{tabular}{|c|c|c|c|c|c|c|c|c|}
\hline Clítico & \multicolumn{5}{|c|}{ Clítico LHE } & \multicolumn{3}{c|}{ Clítico TE } \\
\hline Décadas & $\begin{array}{c}1831- \\
1850\end{array}$ & $\begin{array}{c}1851- \\
1900\end{array}$ & $\begin{array}{c}1901- \\
1950\end{array}$ & $\begin{array}{c}1951- \\
2000\end{array}$ & $\begin{array}{c}1831- \\
1850\end{array}$ & $\begin{array}{c}1851- \\
1900\end{array}$ & $\begin{array}{c}1901- \\
1950\end{array}$ & $\begin{array}{c}1951- \\
2000\end{array}$ \\
\hline Clítico & 142 & 151 & 132 & 29 & 57 & 30 & 21 & 32 \\
\hline TOTAL & \multicolumn{3}{|c|}{454} & \multicolumn{3}{|c|}{140} \\
\hline
\end{tabular}

Tabela 31. Distribuição das ocorrências segundo as décadas e o fator clítico

Pelo resultado da Tabela 31 podemos constatar novamente que o percentual de clítico the é maior se comparado ao clítico te, uma vez que o clítico lhe, aqui, engloba a $2^{\mathrm{a}}$ e a $3^{\mathrm{a}}$ pessoas. O clítico the no início do século XIX apresenta um número alto de ocorrências, 142, atingindo o final do século XX somente com 29 ocorrências. Já o clítico te passou as décadas com uma presença mais constante: no início do século XIX conta com 57 ocorrências e no final do século XX apresenta 32 ocorrências.

A seguir, vejamos as preposições, que, como os clíticos, são de suma importância para este estudo. 
4.2.1.3 O fator década e a preposição

$\mathrm{Na}$ Tabela 32 apresentaremos o cruzamento das preposições ao longo dos séculos.

\begin{tabular}{|c|c|c|c|c|c|c|c|c|}
\hline Preposição & \multicolumn{4}{|c|}{ Preposição A } & \multicolumn{5}{c|}{ Preposição PARA } \\
\hline Décadas & a & b & c & d & a & b & c & d \\
\hline Pronome Forte & 7 & 5 & 3 & 20 & 1 & 0 & 2 & 23 \\
\hline & \multicolumn{3}{|c|}{35} & \multicolumn{5}{c|}{26} \\
\hline
\end{tabular}

Tabela 32. Distribuição das ocorrências segundo as décadas e as preposições

A tabela acima indica que tanto o número da preposição $a$ quanto o da preposição para aumenta no final do século XX, chegando a 20 e 23 ocorrências, respectivamente. Porém, a preposição $a$ era usada nas décadas anteriores com maior frequência em relação à preposição para. Notamos que, no século XIX e início do século XX, o número de preposição para não era substancial, entretanto, no final do século $\mathrm{XX}$ seu número teve um aumento significativo.

Analisando as ocorrências apenas com a $3^{\text {a }}$ pessoa, a Tabela 33 apresenta o mesmo quadro da Tabela 32.

\begin{tabular}{|c|c|c|c|c|c|c|c|c|}
\hline Preposição & \multicolumn{5}{|c|}{ Preposição A } & \multicolumn{3}{c|}{ Preposição PARA } \\
\hline Décadas & $1831-$ & $1851-$ & $1901-$ & $1951-$ & $1831-$ & $1851-$ & $1901-$ & $1951-$ \\
& 1850 & 1900 & 1950 & 2000 & 1850 & 1900 & 1950 & 2000 \\
\hline Pronome Forte & 6 & 3 & 1 & 8 & 1 & 0 & 2 & 11 \\
\hline TOTAL & \multicolumn{3}{|c|}{18} & \multicolumn{5}{c|}{14} \\
\hline
\end{tabular}

Tabela 33. Distribuição das ocorrências de $3^{\text {a }}$ pessoa segundo as décadas e as preposições 
Após analisarmos o decorrer das décadas, parece haver, de fato, uma diminuição dos clíticos e, consequentemente, o aumento da forma nula e a entrada dos pronomes fortes, com o aumento do uso das preposições no final do século XX.

Prosseguiremos nossos cruzamentos, a seguir com o fator verbo e papel temático, fator clítico e preposição.

\subsubsection{O fator verbo}

Berlinck (2005) revelou que tanto a análise de documentos do PBM (cf. Berlinck 1999), como dos documentos do século XIX e XVIII, em um levantamento aleatório de ocorrências de objeto indireto, predominam apenas dois tipos de verbo - de transferência material e de transferência verbal e perceptual. Assim sendo, a discussão de resultados desenvolvida abaixo direciona-se especialmente a essas duas categorias.

Com esse fator analisaremos os demais fatores que se relacionam e que trarão resultados pertinentes para este estudo. A partir deste fator vamos nos deter às ocorrências de $3^{\mathrm{a}}$ pessoa

\subsubsection{O fator verbo e o papel temático}

Como mostrado no capítulo 1, a grande maioria dos dados em Berlink (1997) se caracteriza por um papel temático meta/alvo, o que se explica, em parte, pelo fato de os verbos dicendi serem os mais frequentes na amostra analisada pela autora.

Aqui, vamos nos deter apenas às ocorrências com a $3^{\text {a }}$ pessoa. Vejamos o resultado da tabela abaixo:

\begin{tabular}{|c|c|c|c|c|c|c|c|c|c|c|}
\hline Verbo & \multicolumn{2}{|c|}{ Trans.Material } & \multicolumn{2}{|c|}{ Trans.Verbal } & \multicolumn{2}{|c|}{ Movi.Físico } & Movi.Abstrato & \multicolumn{2}{c|}{ Criação } \\
\hline Papel Temático & \multicolumn{2}{|c|}{ Meta } & \multicolumn{2}{|c|}{ Meta } & \multicolumn{2}{c|}{ Meta } & \multicolumn{2}{c|}{ Meta } & \multicolumn{2}{c|}{ Beneficiário } \\
\hline Clítico & 73 & $49 \%$ & 83 & $38 \%$ & 4 & $57 \%$ & 3 & $60 \%$ & 9 & $60 \%$ \\
\hline Pronome Forte & 11 & $7 \%$ & 16 & $7 \%$ & 1 & $14 \%$ & 0 & $0 \%$ & 4 & $26 \%$ \\
\hline Nulo & 66 & $44 \%$ & 119 & $55 \%$ & 2 & $29 \%$ & 2 & $40 \%$ & 2 & $14 \%$ \\
\hline
\end{tabular}

Tabela 34. Distribuição das ocorrências de $3^{\mathrm{a}}$ pessoa segundo o tipo de verbo e papel temático 
Com o papel temático meta e verbos de transferência material, os clíticos aparecem com a percentagem de $49 \%$, o nulo com $44 \%$ e o pronome forte com $7 \%$. Já com os verbos de transferência verbal, os nulos apresentam um índice maior com a frequência de $55 \%$, seguido pelo clítico, $38 \%$, e pronome forte, $7 \%$. Com os verbos de movimento, os clíticos são mais frequentes, $57 \%$ com verbo de movimento físico e $60 \%$ com movimento abstrato.

Com o papel temático beneficiário e verbo de criação, a frequência de clítico é maior, com $60 \%$. O interessante é que a percentagem da forma preposicionada, $26 \%$, é maior do que a da forma nula, $14 \%$.

\subsubsection{O fator verbo e o clítico}

Observemos a próxima tabela com o cruzamento dos verbos e clíticos.

\begin{tabular}{|c|c|c|c|c|c|c|c|c|c|c|}
\hline Verbo & \multicolumn{2}{|c|}{ Transf.Material } & \multicolumn{2}{|c|}{ Transf.Verbal } & \multicolumn{2}{c|}{ Movim.Físico } & \multicolumn{2}{c|}{ Movim.Abstrato } & \multicolumn{2}{c|}{ Criação } \\
\hline Clítico & LHE & TE & LHE & TE & LHE & TE & LHE & TE & LHE & TE \\
\hline Clítico & 165 & 43 & 249 & 81 & 12 & 4 & 10 & 4 & 18 & 8 \\
\hline TOTAL & \multicolumn{2}{|c|}{208} & \multicolumn{2}{|c|}{330} & \multicolumn{2}{|c|}{16} & \multicolumn{2}{|c|}{14} & \multicolumn{2}{|c|}{26} \\
\hline
\end{tabular}

Tabela 35. Distribuição das ocorrências segundo o tipo de verbo e o fator clítico

Analisando a Tabela 35, constatamos 249 ocorrências com o clítico lhe com verbo de transferência verbal, 165 com verbo de transferência material. Com o clítico te, são 81 ocorrências com verbo de transferência verbal e 43 com transferência material. Os dois tipos de contextos verbais favorecem o clítico lhe, reiterando que, aqui, o clítico lhe aparece conjuntamente em seus usos de $2^{\mathrm{a}}$ e $3^{\mathrm{a}}$ pessoas.

\subsubsection{O fator verbo e a preposição}

Vejamos o que ocorre, agora, com as preposições introdutoras do pronome forte: 


\begin{tabular}{|c|c|c|c|c|c|c|c|c|c|c|}
\hline Verbo & \multicolumn{2}{|c|}{ Transf.Material } & \multicolumn{2}{l|}{ Transf.Verbal } & \multicolumn{2}{l|}{ Movim.Físico } & \multicolumn{2}{l|}{ Movim.Abstrato } & \multicolumn{2}{c|}{ Criação } \\
\hline Preposição & A & PARA & A & PARA & A & PARA & A & PARA & A & PARA \\
\hline Pronome Forte & 14 & 7 & 19 & 13 & 1 & 0 & 0 & 0 & 1 & 6 \\
\hline TOTAL & \multicolumn{2}{|c|}{21} & \multicolumn{2}{|c|}{32} & \multicolumn{2}{|c|}{1} & & & & \\
\end{tabular}

Tabela 36. Distribuição das ocorrências segundo o tipo de verbo e a preposição

Com a preposição $a$, temos 19 ocorrências com verbo de transferência verbal e 14 ocorrências com verbo de transferência material. Com a preposição para temos 13 ocorrências com o verbo de transferência verbal e 7 com transferência material. Portanto, ambos os verbos favorecem o uso da preposição $a$ nas sentenças analisadas.

Os verbos de criação favorecem o uso da preposição para com 6 ocorrências. Em relação aos verbos de movimento, não obtivemos quase nenhuma ocorrência, somente uma com a preposição $a$ em verbo de movimento físico.

Em geral, os resultados mostraram que os verbos dicendi são os mais frequentes com o papel temático meta com a variante nula. Os verbos de transferência verbal são os mais frequentes, tanto com as preposições a e para, quanto com os clíticos lhe e te.

A seguir, analisaremos o resultado do cruzamento desse fator com pessoa gramatical.

\subsubsection{O fator clítico}

Uma das hipóteses levantadas por este estudo é que ocorreria a migração do pronome lhe ( $3^{\mathrm{a}}$ pessoa) para a $2^{\mathrm{a}}$ pessoa, verifiquemos os dados abaixo.

Observe-se a tabela que se segue:

\begin{tabular}{|c|c|c|c|}
\hline Clítico & \multicolumn{2}{|c|}{ Clítico LHE } & Clítico TE \\
\hline Pessoa & $2^{\mathrm{a}}$ Pessoa & $3^{\mathrm{a}}$ Pessoa & $2^{\mathrm{a}}$ Pessoa \\
\hline Clítico & 282 & 172 & 140 \\
\hline TOTAL & \multicolumn{2}{|c|}{454} & 140 \\
\hline
\end{tabular}


Tabela 37. Distribuição das ocorrências segundo o fator clítico e a pessoa gramatical

Para ilustrar as ocorrências, tanto do clítico the de $2^{\mathrm{a}}$ e $3^{\mathrm{a}}$ pessoas, quanto o clítico te de $2^{\mathrm{a}}$, apresentamos o Gráfico 7 a seguir.

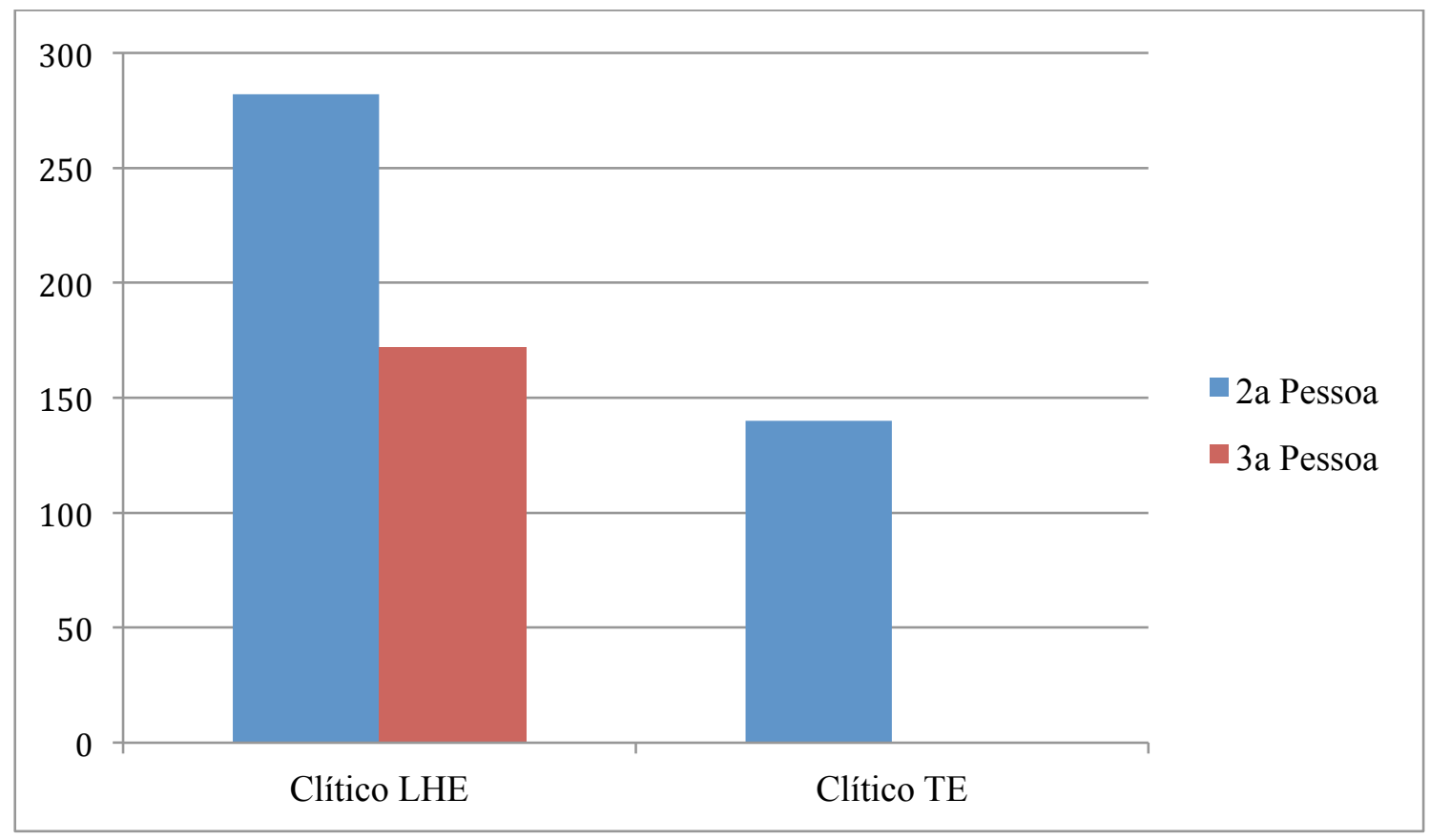

Gráfico 7. O fator clítico e a pessoa gramatical

Como observado anteriormente na tabela 38 , o clítico lhe de $2^{\mathrm{a}}$ pessoa aparece com 282 ocorrências. Por sua vez, o clítico the de $3^{\text {a }}$ pessoa apresenta 172 dados, totalizando 454 ocorrências. Já o clítico te perfaz 140 ocorrências.

Freire (2005) constatou a baixa frequência de clítico tanto na função acusativa quanto na função dativa de $3^{\text {a }}$ pessoa, sendo seu uso condicionado a eventos de comunicação de [+ letramento]. De fato, neste presente estudo ao analisarmos o clítico dativo observamos que seu número cai em referência à $3^{\mathrm{a}}$ pessoa e parece migrar para a referência à $2^{\mathrm{a}}$ pessoa.

De um modo geral, pelos resultados extraídos do conjunto das peças de teatro que compõem este trabalho, observamos um processo de mudança em curso, o que parece confirmar as hipóteses levantadas que orientam nosso estudo. 


\section{CONSIDERAÇÕES FINAIS}

Neste estudo, procurou-se descrever e analisar, dentro dos pressupostos da Teoria dos Princípios e Parâmetros e a Teoria da Variação e Mudança Linguísticas, a concorrência das formas pronominais que expressam a realização do OI anafórico na história do PB, com base em peças de teatro dos séculos XIX e XX.

Partindo dos vários trabalhos que trataram do $\mathrm{OI}$ no $\mathrm{PB}$, olhamos os dados acalentando as seguintes hipóteses:

(a) os clíticos dativos se tornam a variante menos produtiva;

(b) as formas nulas e o pronome tônico introduzido por preposição passam a ser as formas mais frequentes;

(c) ocorre um aumento no uso da preposição para em detrimento da preposição $a$;

(d) ocorre a migração do pronome lhe ( $3^{\mathrm{a}}$ pessoa) para a $2^{\mathrm{a}}$ pessoa, em coocorrência com o clítico te.

Como se viu pelos resultados quantitativos descritos no capítulo 4, estas hipóteses se confirmaram.

Primeiramente, constata-se o aumento gradativo da forma nula, ao longo dos séculos. Inicialmente, no século XIX, a frequência desta variante era, em média, 32-33\%. No início do século XX, passou para 57\% até chegar aos $68 \%$ no final desse século. Consequentemente, houve diminuição gradativa do clítico lhe no decorrer das décadas. A frequência de clítico que atinge $66 \%$ no século XIX, cai para $42 \%$ no início do século $\mathrm{XX}$, e chega aos 18\% no final da última década. Tais resultados vão ao encontro das constatações de Berlinck (1999) e Freire (2000), já discutidas anteriormente. Em relação ao pronome forte, no final do século XX notamos um aumento (14\%).

Se levarmos em conta o vernáculo, em oposição às formas adquiridas na escolaridade, podemos considerar que a queda do clítico lhe no uso de $3^{\text {a }}$ pessoa já é uma 
mudança implementada. Ao contrário, as estratégias inovadoras, forma nula e preposicionada, estão em um processo de implementação.

Os resultados relativos às preposições confirmam que preposição $a$, apesar de ainda ser frequente nos dois séculos, apresenta redução no século XX. A preposição para começa a ser introduzida neste século. Tal tendência corrobora com os estudos apresentados, como de Berlinck (1999), Bispo (2004), Torres Morais \& Berlinck (2006) e outros.

Os dados das peças analisadas assinalaram que, com relação à pessoa gramatical, o clítico lhe é mais utilizado na referenciação à segunda pessoa em comparação à terceira pessoa. Trabalhos, como de Berlinck (1999), mostram um aumento substancial da ocorrência do clítico lhe com a segunda pessoa.

Retomando trabalhos que levaram em conta a perspectiva comparativa entre o PB e o PE, apresentados no capítulo 1, discutiu-se ainda, nesta dissertação, que a mudança na expressão anafórica do OI no PB decorre de reanálises morfológicas na expressão do OI dativo, levando a uma mudança de natureza paramétrica, relacionada à perda do núcleo aplicativo, um núcleo funcional, disponibilizado na GU, especializado em introduzir OIs dativos.

Espera-se que este trabalho possa contribuir com os estudos dos complementos dativos no PB. 


\section{REFERÊNCIAS BIBLIOGRÁFICAS}

Anais do Primeiro Congresso Brasileiro de Língua Falada no Teatro. Rio de Janeiro. Ministério da Educação e Cultura, 1958.

BECHARA, Evanildo. Moderna Gramática Portuguesa. $37^{\mathrm{a}}$ ed. Rio de Janeiro: Lucerna, 2001.

BERLINCK, Rosane de Andrade. The PortugueseDative. In: W. Van Belle \& W. Van Langendonck (eds.). The Dative. Volume I: Descriptive Studies. Amsterdam/Philadelphia: John Benjamins Publishing Company, 1996.

A Expressão do Objeto Indireto no Português do Brasil. Comunicação apresentada no X Seminário do CELLIP (Centro de Estudos Linguísticos e Literários do Paraná), Londrina, 24 - 26/10/1996b.

Sobre a Realização do Objeto Indireto no Português do Brasil. Anais do II Encontro do Circuito de Estudos Linguísticos do Sul - Celsul. Florianópolis, 1997.

O Objeto Indireto no Português Brasileiro do Século XIX. Comunicação apresentada no II Congresso Nacional da Abralin. Florianópolis, 1999.

Complementos Preposicionados: Variação e Mudança no Português Brasileiro. Conferência proferida no Congresso "500 anos da Língua Portuguesa no Brasil”. Évora, Portugal. Universidade de Évora, 2000.

Dativo ou Locativo? Sobre Sentidos e Formas do "Dativo" no Português. In: Revista Letras.n.56. Curitiba: Editora UFPR,jul/dez, 2001.p. 159-175.

O Objeto Indireto no Português Brasileiro: um Estudo Diacrônico. In: Massini-Cagliari, Gladis. Murakawa, Clotilde de A. A., Berlinck, Rosane de A. \& Guedes, Marymarcia (orgs.) Estudos de Linguística História do Português. Araraquara: Laboratório Editorial FCL/UNESP; São Paulo: Cultura Acadêmica Editora, 2005.

. BARBOSA, J. B.; MARINE, T. de C. Reflexões Teórico-metodológicas sobre Fontes para o Estudo Histórico da Língua. Revista da ABRALIN, v. 7, n. 2, jul/dez 2008. p. 169-195.

BERRETTINI, Célia. O Teatro Ontem e Hoje. São Paulo: Perspectiva, 1980.

BISPO, Karla C. I. Ferreira. Dissertação de mestrado: A Sintaxe do Objeto Indireto no Português. Brasília, 2004.

BRESCANCINI, Claudia \& BISOL, Leda. Fonologia e Variação: Recortes do Português Brasileiro. Porto Alegre: EDIPUCRS, 2002. 
CACCIAGLIA, Mario. Pequena História do Teatro no Brasil. São Paulo: Editora da Universidade de São Paulo, 1986.

CAFEZEIRO, Edwaldo. História do Teatro Brasileiro: um Percurso de Anchieta a Nelson Rodrigues. Rio de Janeiro: Editora UFRJ: Eduerj - Funarte, 1996.

CASTILHO, Ataliba T. de. Gramática do Português Brasileiro. $1^{\mathrm{a}}$ ed. São Paulo: Contexto, 2010.

CHOMSKY, Noam. Lectures on Government and Binding. Dordrecht: Foris, 1981.

Knowledge of Languages. New York: Praeger, 1986.

CUNHA, Celso \& CINTRA, Luis F. L. Nova Gramática do Português Contemporâneo. Rio de Janeiro: Nova Fronteira, 2001.

CYRINO, Sonia. M. L. Observações sobre a Mudança Diacrônica no Português do Brasil: Objeto Nulo e Clíticos. In: Roberts, Ian \& Kato, Mary A. (orgs.) Português Brasileiro: Uma Viagem Diacrônica. Campinas: Editora da Unicamp, 1993.

Elementos Nulos Pós-Verbais no Português Brasileiro Oral Contemporâneo. In: Moura Neves, Maria H. de (org.) Gramática do Português Falado, Volume VII: Novos Estudos.São Paulo: Humanitas/ FFLCH/USP; Campinas: Editora da Unicamp, 1999.

DUARTE, M. E .L. Do Pronome Nulo ao Pronome Pleno: a Trajetória do Sujeito no Português do Brasil. In: ROBERTS, I.; KATO, M.A. (Org.). Português brasileiro: uma viagem diacrônica. Campinas: Ed. UNICAMP, 1993. p. 107-128.

FREIRE, Gilson C. Dissertação de Mestrado: Os Clíticos de Terceira Pessoa e as Estratégias para sua Substituição na Fala Culta Brasileira e Lusitana. Rio de Janeiro, 2000.

Tese de Doutorado: A Realização do Acusativo e do Dativo Anafóricos de Terceira Pessoa na Escrita Brasileira e Lusitana. Rio de Janeiro, 2005.

GALVES, Charlotte. O Enfraquecimento da Concordância no Português Brasileiro. In: Roberts, Ian \& Kato, Mary A. (orgs.) Português Brasileiro: Uma Viagem Diacrônica. Campinas: Editora da Unicamp, 1993.

Ensaios sobre as Gramáticas do Português. Campinas: Editora da Unicamp, 2001. 
\& ABAURRE, Maria B. M. Os Clíticos no Português Brasileiro: Elementos para uma Abordagem Sintático-fonológica. In: Castilho, Ataliba T. de \& Basílio, Margarida (orgs.) Gramática do Português Falado, Volume IV: Estudos Descritivos. Campinas: Editora da Unicamp, 2002.

GOMES, Christina A. Variação e Mudança na Expressão do Dativo no Português Brasileiro. In: Paiva, Maria da C. de \& Duarte, Maria Eugenia L. (orgs.) Mudança Linguística em Tempo Real. Rio de Janeiro: Contra Capa Livraria, 2003.

HESSEL, Lotar. O Teatro no Brasil (sob D. Pedro II - $2^{a}$ parte). Porto Alegre: Editora da Universidade UFRGS, 1986.

KROCH, Anthony S. Reflexes of Grammar in Patterns of Language Change. In: Language Variation and Change 1. 1989.p.199-244.

Syntactic Change. In: BALTIN, M. \& COLLINS, C. The Handbook of Contemporary Syntactic Theory. Oxford. Blackwell, 2000.p.629-739.

Modeling Language Change and Language Acquisition.University of Pennsylvania. 2001.

LABOV, William. Sociolinguistic Patterns. Philadelphia: University of Pennsylvania Press, 1972.

Principles of Linguistic Change. Vol.1: Internal Factors. Oxford,UK/ Cambridge, USA: Blackwell, 1994.

. Padrões Sociolinguísticos. São Paulo: Parábola Editorial, 2008.

LEVI, Clóvis. Teatro Brasileiro: um Panorama do Século XX. Rio de Janeiro: Funarte; São Paulo: Atração Produções Ilimitada, 1997.

LIGHTFOOT, David.Principles of Diachronic Syntax. Cambridge: Cambridge University Press, 1979.

. Catastrophic Change and Learning Theory.In: Língua 100: Elsevier, 1997.

The Development of Language. Oxford: Blackwell, 1999.

MAGALDI, Sábato.Moderna Dramaturgia Brasileira. São Paulo: Editora Perspectiva, 1998.

Panorama do Teatro Brasileiro. $4^{\text {a }}$ edição. São Paulo: Global, 1999. 
MARTINS, Ana M. Clíticos na História do Português à Luz do Teatro Vicentino. Estudos de Linguística Galega v. 3. Universidade de Santiago de Compostela, 2011.p.83109.

MATEUS, Maria Helena M. et al. Gramática da Língua Portuguesa. Coimbra: Livraria Almedina, 1989.

MIOTO, Carlos. Manual de Sintaxe. $2^{\mathrm{a}}$ ed. Florianópolis: Insular, 2000.

MONTEIRO, José L. PronomesPessoais: Subsídios para uma Gramática do Português do Brasil. Fortaleza: Edições UFC, 1994.

Para compreender Labov. Petrópolis, RJ: Vozes, 2000.

NUNES, Jairo M. Direção de Cliticização, Objeto Nulo e Pronome Tônico na Posição de Objeto em Português Brasileiro. In: Roberts, Ian \& Kato, Mary A. (orgs.) Português Brasileiro: Uma Viagem Diacrônica. Campinas: Editora da Unicamp, 1993.

OLIVEIRA, Paulo Roberto Correia de. Aspectos do Teatro Brasileiro. Curitiba: Juruá, 1999.

PAGOTTO, Emilio G. Clíticos, Mudança e Seleção Natural.In: Roberts, Ian \& Kato, Mary A. (orgs.) Português Brasileiro: Uma Viagem Diacrônica. Campinas: Editora da Unicamp, 1993.

PRADO, Decio de A.O Teatro Brasileiro Moderno (1930-1980). São Paulo: Editora Perspectiva, 1988.

Teatro de Anchieta a Alencar. São Paulo: Editora Perspectiva, 1993.

Apresentação do Teatro Brasileiro Moderno (Crítica Teatral de 1947-1955).

São Paulo: Editora Perspectiva, 2001.

Teatro em Progresso (Crítica Teatral 1955-1974). São Paulo: Editora Perspectiva, 2002.

RAPOSO, Eduardo de P. Teoria da Gramática. A Faculdade da Linguagem. Lisboa: Caminho, 1992.

Some Observations on the Pronominal System of Portuguese.Catalan Working Papers in Linguistics, VI, 1999.

ROBERTS, Ian. Diachronic Syntax. Oxford: Oxford University Press, 2007.

ROCHA LIMA, Carlos H. da.Gramática Normativa da Língua Portuguesa. Rio de Janeiro: José Olympio, 2003. 
SCHERRE, Maria M. P \& SILVA, Giselle M. de O. Padrões Sociolinguísticos - Análise de Fenômenos variáveis do Português Falado na Cidade do Rio de Janeiro. Rio de Janeiro: Tempo Brasileiro: Departamento de Linguística e Filologia, UFRJ, 1996.

\& NARO, Anthony J. Análise Quantitativa e Tópicos de Interpretação do Varbrul. In: MOLLICA, Maria C. \& BRAGA, Maria L. (orgs.) Introdução à Sociolinguística: o Tratamento da Variação. São Paulo: Contexto, 2003.

SANTOS, M. A. A. dos. Dissertação de Mestrado: Pronomes Pessoais de $2^{a}$ e $3^{a}$ Pessoas com Função Dativa no Português Brasileiro. São Paulo, 2005.

TARALlO, Fernando. A Pesquisa Sócio-Linguística. São Paulo: Ática, 1985.

\& KATO, Mary.Harmonia trans-sistêmica: variação intra-e inter-linguística. Preedição 5, 1989.

TORRES MORAIS, Maria Aparecida C. R. Aspectos Diacrônicos do Sistema Pronominal no Português Brasileiro. Atas do II Encontro Nacional do GELCO: Integração Linguística, Étnica e Social. In: Denize E. G. da Silva (org.) Oficina Editorial do Instituto de Letras da UnB. 2004.

Tese de Livre Docência - Os Dativos. São Paulo: Universidade de São Paulo, 2007.

Conversando sobre o Objeto Indireto Nulo no Português Brasileiro. Estudos da Língua(gem) v. $8 \mathrm{n}^{\mathrm{o}}$ 1. Vitória da Conquista, 2010.p.171-185.

Sentenças Bitransitivas e Objeto Indireto no Português Brasileiro. In: Revista Linha d'Água v. 25 nº 2. São Paulo: Humanitas FFLCH USP, 2012.

\& BERLINCK, Rosane de A. A Preposição a e a Caracterização doObjeto Indireto: Aspectos Sincrônicos e Diacrônicos. Apresentado no V Congresso do PHPB, Ouro Preto 14-17 outubro 2002.

\& BERLINCK, Rosane de A. A Caracterização do Objeto Indireto no Português: Aspectos Sincrônicos e Diacrônicos. In: LOBO, Tânia et al. (eds.) Novos Dados, Novas Análises. Vol. VI. Tomo I, p. 73-106. Salvador: EDUFBA, 2006.

\& BERLINCK, Rosane de A. "Eu Disse pra Ele" ou "Disse-lhe a Ele": A Expressão do Dativo nas Variedades Brasileira e Europeia do Português. In: CASTILHO, Ataliba T. de; TORRES MORAIS, Maria Aparecida C. R.; LOPES, Ruth E. V.; CYRINO, Sonia M. L. (orgs.) Descrição, História e Aquisição do Português Brasileiro - Estudos dedicados a Mary Aizawa Kato.São Paulo: Fapesp; Campinas: Pontes Editores, 2007.p.61-83 
\& BERLINCK, Rosane de Andrade .Em busca do português paulista. In: Maria Aparecida C.R. Torres Morais \& Maria Lúcia da C.V.de O. Andrade. (Org.). História do Português Paulista- Série estudos Vol II. 1 ed. Campinas: IEL Publicações, 2009.p.217248.

\& RIBEIRO, Ilza. Contraste da Sintaxe dos Clíticos no Português Europeu e Português Brasileiro. In: Linha d'Água n ${ }^{\circ}$ 17. São Paulo: Humanitas FFLCH USP, 2005.

\& SALLES, Heloisa M. M. L. ParametricChange in theGrammaticalEncodingofIndirectObjects in BrazilianPortuguese, 2010.

WEINREICH, Uriel; LABOV, William; HERZOG, Marvin (1968) Empirical Foundations for a Theory of Language Change. In: LEHMANN, W.; MALKIEL, Y. (eds.) Directions for Historical Linguistics. Austin. University of Texas Press, 1968. p. 97-195. 